Portland State University

PDXScholar

5-1974

\title{
The politics of education - An analysis of selected cases and controversies in American education
}

\author{
Lawrence Robert Stoffel \\ Portland State University
}

Follow this and additional works at: https://pdxscholar.library.pdx.edu/open_access_etds

Part of the Education Commons, and the Political Science Commons Let us know how access to this document benefits you.

\section{Recommended Citation}

Stoffel, Lawrence Robert, "The politics of education -- An analysis of selected cases and controversies in American education" (1974). Dissertations and Theses. Paper 1964.

https://doi.org/10.15760/etd.1963

This Thesis is brought to you for free and open access. It has been accepted for inclusion in Dissertations and Theses by an authorized administrator of PDXScholar. Please contact us if we can make this document more accessible: pdxscholar@pdx.edu. 
AN ABSTRACT OF THE THESIS OF Lawrence Robert Stoffel for the Master of Science In Political Science presented May 13, 1974.

Title: The Politics of Education-- An Analysis of Selected Cases and Controversies in American Education.

APPROVED BY MEMBERS OF THE THESIS COMMITTEE:

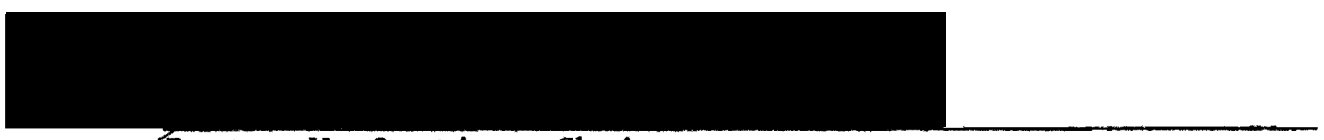

Burton W. Onstine, Chairman

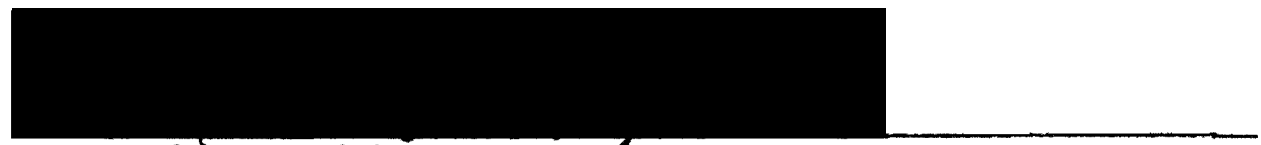

Merle G. Wright

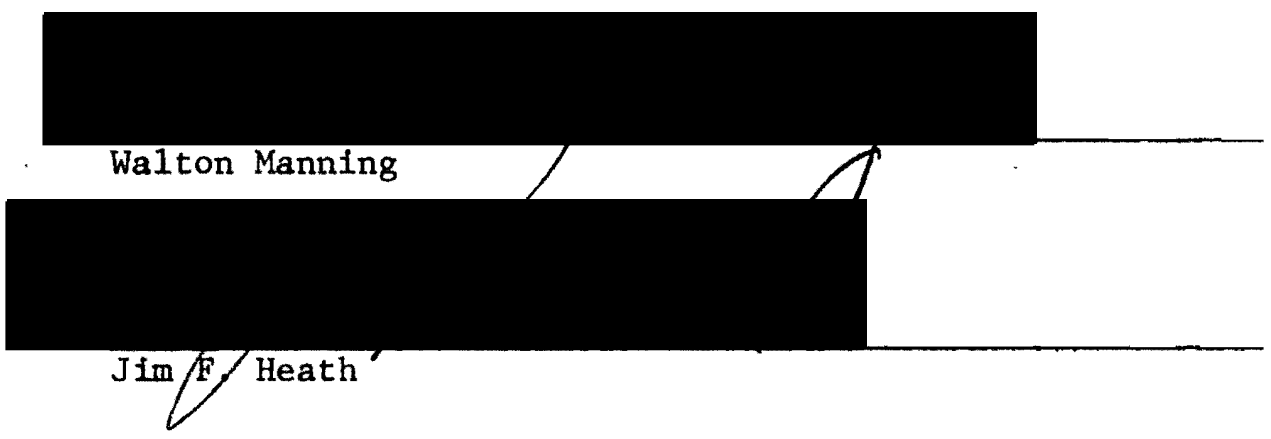

This study compiles a series of cases and controversies in American education, from the popularization of public education in the mid-1800's to the present, and then reviews them to determine scholarly political aspects, common themes, and trends. It then applies the Identified themes to a model of "the school as a responsive political system" fashloned after David Easton's "Dynamic Response Model of a Political System" to demonstrate the operative nature of the themes. 
The paper reviews the plight of Negro education in Alabama after the Civil War unt11 1901. It discusses accommodation in the realm of education as the Unfted States began its massive move toward Industrialization and the corresponding move toward child-centered education. It discusses controversies in the reform era of the $1920^{\prime} \mathrm{s}$ and the turmoll to the educational system in the cold war period after World War II. It looks at cases involving sectarian to non-sectarian education of the $1800^{\prime} \mathrm{s}$ and the anguish of disappointed educators with the trends of public education and the Progressive Education Association in the Great Depression period. Finally, the paper reviews cases involving charges of indoctrination against public schools, recent controversies (since 1954) in integration and segregation, and cases involving modern educational alternatives. The paper identifies three themes consistently present in educational controversy: 1) the desire of the people to have all children successfully master the basic fundamentals of reading, writIng and arithmetic, 2) the desire of the people to have the schools emphasize moral and spiritual values which are simflar to their own, and 3) the opposition of the people to what was belleved by them to be an attempt by the school to foster some dimly defined kind of soclalistic theory which would replace individualism with group goals and competition with cooperation. The paper then analyzes the cases and situations with respect to the identified themes.

The paper uses the framework developed by David Easton to construct a simple framework from which to view the three Identifled themes. It shows the three themes to be the true demands behind a 
varlety of issues which create controversy in education. Briefly, the paper then reviews the adaption of the educational system to the demands. Finally, the paper concludes that "the school" will persist as a viable political system if it can accurately analyze the basic nature of the issues confronting it, in terms of the three identified themes. 
THE POLITICS OF EDUCATION -- AN ANALYSIS OF

SELECTED CASES AND CONTROVERSIES IN AMERICAN EDUCATION

by

LAWRENCE ROBERT STOFFEL

A thesis submitted in partial fulfillment of the requirements for the degree of

MASTER OF SCIENCE

in

POLITICAL SCIENCE

Portland State University

1974 
TO THE OFFICE OF GRADUATE STUDIES AND RESEARCH:

The members of the committee approve the thesis of Lawrence Robert Stoffel presented May 13, 1974.
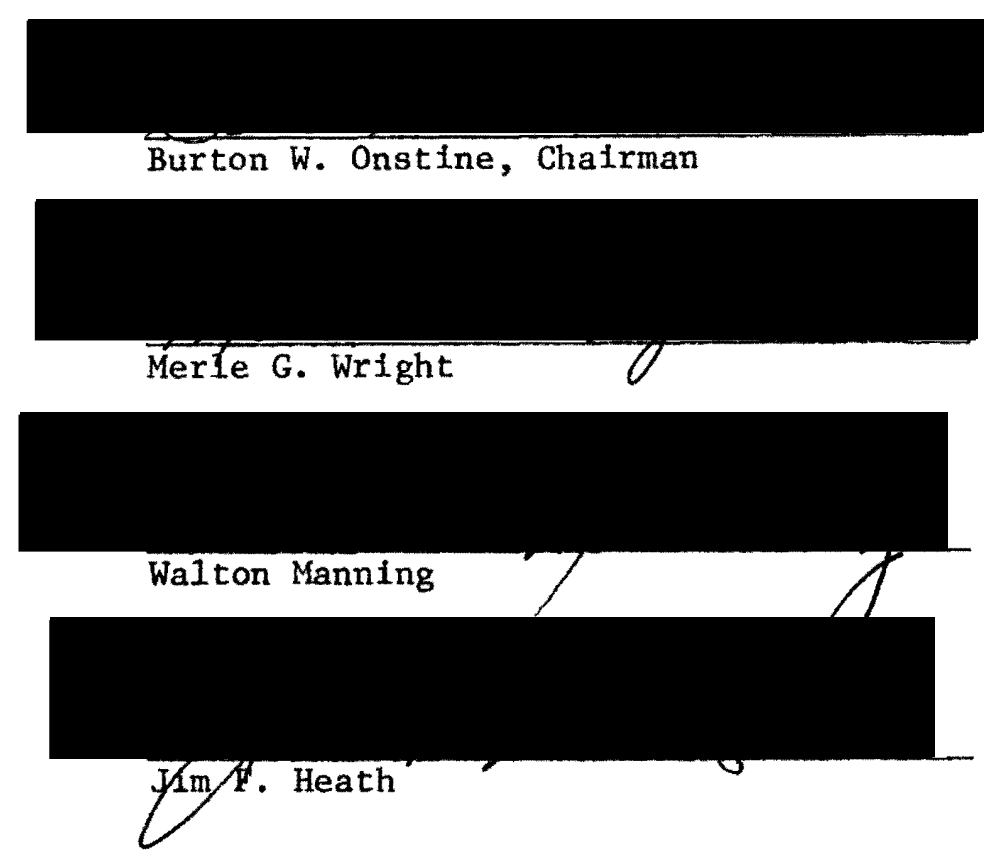

APPROVED :

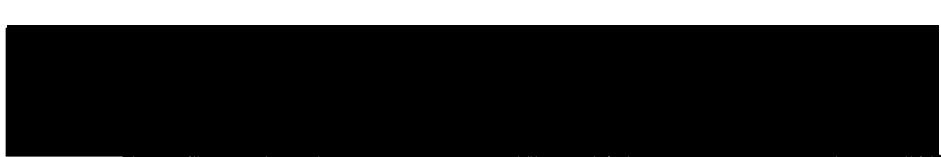

Norman N. Greene, Head, Department of Political Sclence

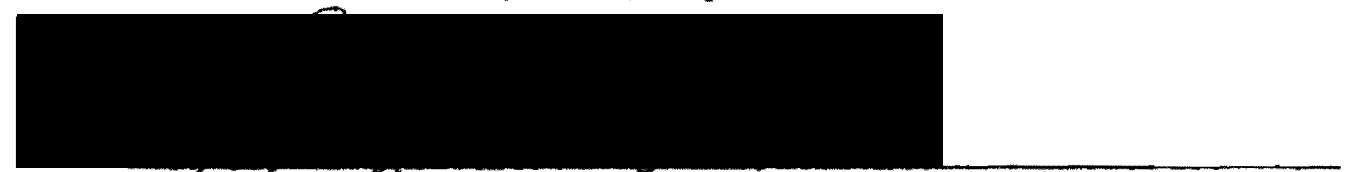

David T. Clark, Dean of Graduate Studies and Research 


\section{ACKNOWLEDGEMENTS}

The writer wishes to express his appreciation to the members of the committee who read this thesis, Dr. Jim F. Heath, Dr. Walton Manning, Mr. Merle Wright and to the chairman of the committee, Dr. Burton Onstine. Comments by the members at various points of development of the thesis were invaluable. Also, the encouragement given by the members at various stages in the research and development of the thesis is deeply appreciated.

The writer is indebted to his wife Lenore for her continual understanding and patience without which this paper might not have been posstble. And to the new arrival in the household, David, whose good humor allowed completion of the paper. His competition for use of the typewriter is undoubtedly an underlying reason for the timely completion of this paper.

A special thanks must be given to Mrs. Marie Brown of the Graduate Studies Office who was so often helpful with Interpretations and guidance.

The writer finally wishes to express his thanks to Barbara Wiegele, whose persistence in typing put the study into a proper form. 
TABLE OF CONTENTS

PAGE

ACKNOWLEDGEMENTS ....................... . . . . . . . .

LIST OF FIGURES . . . . . . . . . . . . . . . . v

CHAPTER

I INTRODUCTION ..................... 1

II SELECTED CASES AND CONTROVERSIES . . . . . . . 7

The New Black Citizen in Education. . . . . 12

Industrialization -- The Nation Adapts . . . . 20

An Experiment in Progressivism . . . . . . . 23

From Reform to Depression . . . . . . . . 32

The Red Scare -- Post-World War II . . . . . 41

The Roots of Public Education . . . . . . 53

Dare the Schools Build a New Social Order? . . . 58

The School-Charges of Indoctrination . . . . . 62

Black and White Education -- Separate and Unequal 69

Educational Alternatives -- Threat to Tradition . 76

III ENDURING THEMES IN AMERICAN EDUCATION ....... 83

Analysis ................. 85

The School as a Responsive Political System . . 118

IV. CONCLUSIONS AND RECOMMENDATIONS . . . . . . . . 133

Summary and Conclusions . . . . . . . . 133

Recommendations ............ 144

BIBLIOGRAPHY . . . . . . . . . . . . . . . . . . 150 


\section{LIST OF FIGURES}

PAGE

\section{FIGURE}

1 A Dynamic Response Model of a Political System

2. The School as a Responstue Polftical System 
CHAPTER I

INTRODUCTION

Recent reading by this student in political science courses has aroused a significant interest in politics and education. It was therefore determined that a way would be sought to develop some plan to further this interest in a scholarly pursuit of this general topic.

It appears a truism that almost any student who approaches a scholarly topic of a general nature in almost any fleld of American life finds so many intermingling entanglements which cross traditional subject matter disciplines that one is forced to choose some small aspect and explore it in depth or to follow some general theme and hunt for common threads of principles, concepts, or actions.

Where politics and education are concerned, the first approach is adequate to explain current topics or trends in education, but it is unable to offer the long-term, time-proven analysis that a historical case-study approach might offer. If, for example one considers the possible political aspects of academic freedom of the classroom teacher in a public school setting, he is immediately confronted with a complex situation which may be reported in various sources to different degrees. Such a situation is undoubtedly not recorded In any consistent or comprehensive publication or media for that express purpose. A typical situation in the schools might occur 
in the following manner. First a teacher comes under criticism from some public or professional group. The initial account may be reported by the local media but as time passes reporting may become less and less specific. The final disposition of such a case may be reported with little detail making in-depth political analysis of the case nearly Impossible. Discussion of this situation can be verified with almost any educator who has followed controversy in education at the state or national levels. At the local level one can observe many cases over the years in which teachers have been discharged with widespread publicity and then little or no further mention of the case in the media. This can be noted locally in a recent case in a Portland high school in which a teacher was discharged as well as in the case of a Eugene, Oregon teacher. When one multiplies this by the thousands of cases which occur across the nation and considers the lack of a concentrated and accurate source which compiles data, one becomes aware that any given research effort might result in a superficial inquiry almost at random into a complexity of individual issues. The American Federation of Teachers and the National Education Association have provided defense assistance to cases involving discharge of teachers where freedom of the teacher was an issue. Records of these cases are available but they obviously cover only a fraction of those cases which have occurred and are often reported in a manner which reflects the activities and views of the professional group, with little concern for other significant aspects. These facts, however are not convincingly persuastve in arriving at a conclusion that such a study is not productive because of the very volume which must exist and the 
lack of any clear-cut method of assessing the data.

This problem, although different to handle in any traditional fashion, may be somewhat reduced with the aid of a systems approach to political analysis as described in David Easton's, A Systems Approach of Political Life. ${ }^{1}$ Figure 1 shows the model that Easton uses to describe a political system of a dynamic nature. It recognizes the ever changing environment and the resultant adjustment that occurs withIn the political system. Briefly, it sees demands and support for a given system in a given environment and transforms them into outputs through a process which he calls conversion. The key to the conversion process is what he calls authorities. To stop at this point though would be to ignore a fundamental question of how the given political system reacts, adapts and resolves its place in a given environment when placed under conditions of stress, stress being a condition which requires the given political system to recognize new forms of behavior, values that it must react to or new orfentations that it must assume if it is to remain as a viable, continuing entity. To this point Easton addresses himself to the feedback loop, a feature that allows the system to take notice of the outputs by having them return to the environment through the feedback loop. The process then continues with various aspects of demands and supports being formulated through the total environment as inputs to the conversion process. The political

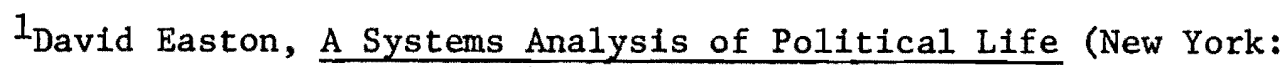
John Wiley and Sons, Inc., 1965), p. 30. 


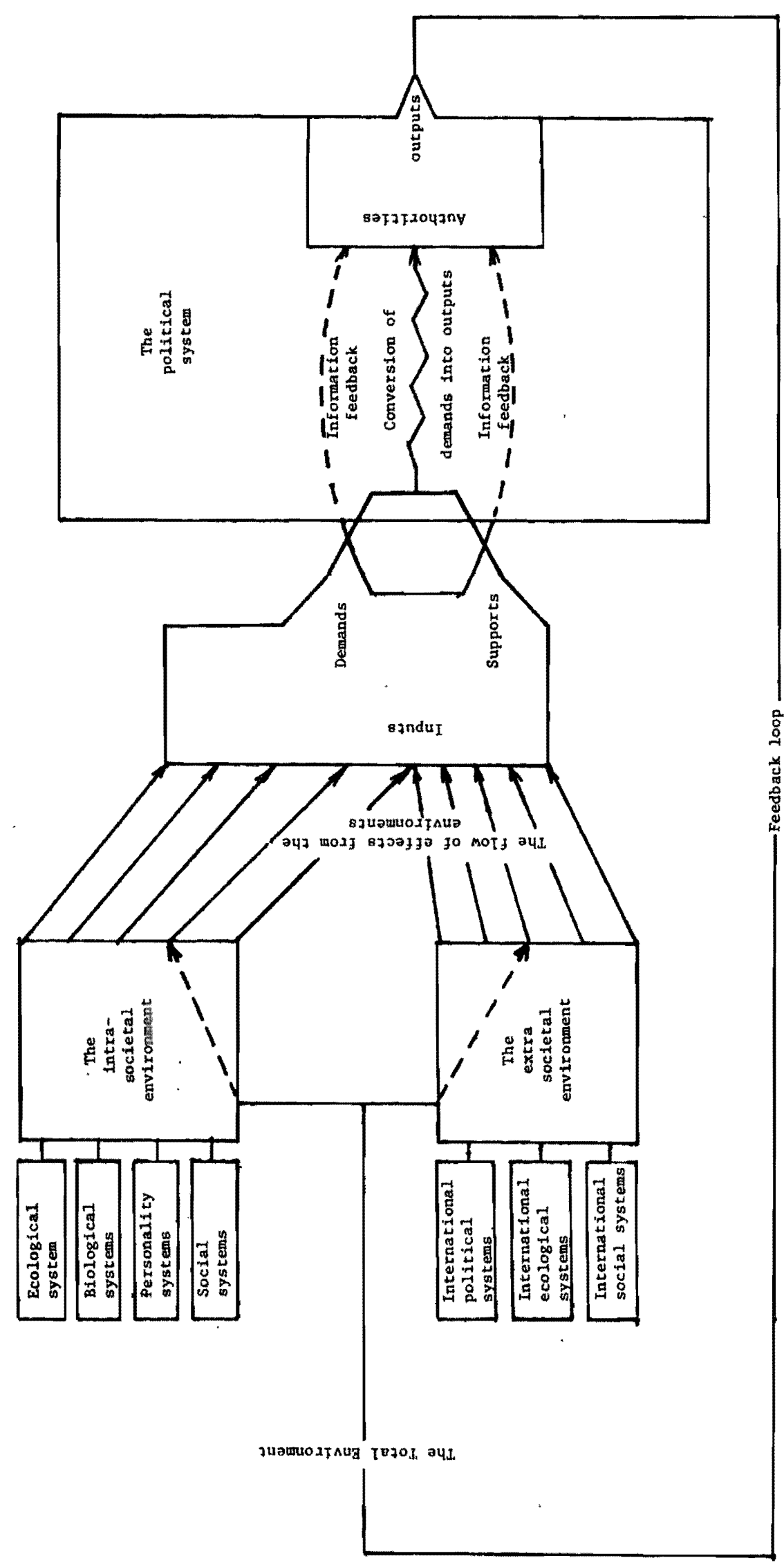

贾 
system then, after recognizing the demands and supports through the mechanisms of information feedback, tends to adjust and react so as to Insure its continuance.

Such a system can be likened to any political system or agency of a polftical nature. By using the basic framework that Easton has constructed, a similar approach can be taken with the school as a public institution and as a political entity. But due to the exceedingly complex nature of the realm of education in terms of support and demands, no specific model construction will be attempted at this point. What will be done however is to use Easton's model in such a manner as to identify the nature of the demands and to observe these ultimately on a simplified model of interaction.

It was decided then, to examine a variety of cases and situations in detall where controversy was widely reported (or accurately reported in an acceptable source). These cases and situations would then be analyzed in an effort to extract scholarly political aspects, common themes and trends. The analysis would then be developed in general terms and applied to a model, "the school as a responsive political system." One, and only one criterion would be used for the selection of cases...the quantity and quality of avallable data. Such an approach would allow one to Identify themes, not just in terms of spectfics of the day but general aspects which would conceivably be common to any controversy in education. By then placing the identified themes into the context of a political system such as that of Easton's, one is able to better understand the total environment in which the schools operate. And while it is not expected that the aspects 
Identifled would encompass all of the demands acting upon "the school" as a political system, it is apparent that the identification of these themes, however limited, would be a contribution to the study of "the school" as a political system. It was to this purpose that the cases were selected, described and analyzed in the material which follows. 


\section{CHAPTER II}

\section{SELECTED CASES AND SITUATIONS}

As previously described, this study set out to find scholarly political aspects, common themes, and trends in the realm of the politics of education through the use of a case study approach. From a practical point of view, it was also decided that the limitations of data sources required that the cases be chosen primarily on the basis of the avallability of data about a case in terms of quality and quantity. The cases which follow were chosen to encompass the time period from the mid-1800's to the present. 1 And since the cases discussed often overlap chronologically, some belng of short duration, others sometimes covering a span of years, a basically random sequence of organization is followed. This manner of organization recognizes that the identified themes would be independent of the sequence of history, and as such would not be dependent upon order for basic understanding and interpretation. Furthermore it is suggested that the scholarly aspects of such a study are best served by presenting the cases in such a manner because of the greater difficulty of promoting any preconceived notions which are time dependent. To provide a minimum amount of order though, cases occurring during Identical time perlods with simflar themes are placed under subtitles most fitting

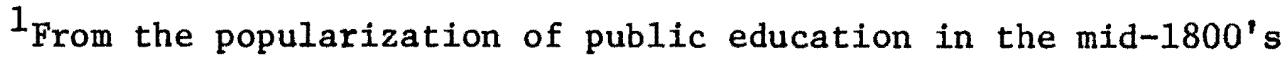
to the present.
} 
the nature of the period and the cases. In addition, no attempt is made in this chapter to analyze or develop common themes among the cases and controversies. To maintain the methodology proposed previously, this will be done in a separate chapter following the case descriptions.

The cases and situations described in this chapter must be read and analyzed broadly in terms of what is meant by political. It is multi-faceted. It pertains to the techniques by which individuals or groups seek to capture or maintain political power. ${ }^{2}$ It may be viewed as an activity which expresses the wills and interests of individuals In the ordering of their public affairs. Moreover, it views the relationships of influence and influentials in the governing of any human society. The complexity and broadness of the term politics in any discussion of education can best be illustrated by the following quotation:

...politics in the words of the political scientist Michael Oakeshott, 'is the activity of attending to the general arrangements of a people.' Education and schools are a part of those arrangements so it is not surprising that educators find themselves caught up in the pressures and conflicts that inevitably ensue when human activities are institutionalized....

Evidence of this politicalization is all around us. Perhaps the most obvious evidence can be seen in the role played by the teachers' organizations. Today we are particularly aware of teacher militancy because of the recent upsurge of the union movement, but in a more quiet fashion teachers' groups have for many years sought a political role. They have always tended to consider

${ }^{2}$ In terms of the school, it must be viewed in terms of a governmental entity, of a variety of interest groups, of the interplay between and among professionals, publics and of course students, and many other aspects of the complex environment of education. 
education unlque among public services, deserving preferential treatment. In the name of anti-politics, they have sought to enjoy the fruits of the political system without sharing the responsibilities. They have lobbled for first call on state and local revenues and for separate electlons for school boards, and have always tried to get what they want in the way of monies without accountability. In short, their politics has taken the form of trying to make the schools autonomous, divorcing them from the natural and normal work-

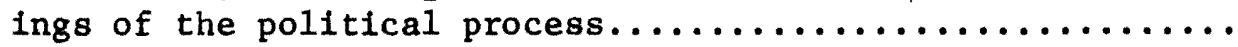

Even the courts have come to play a role in this politicalization....

One of the most famous examples of judicial action in educational matters occurred some years ago in Washington, D. C. when a circuit court judge ordered the abandonment of a track system of abllity grouping in the local schools (and incidentally forced out the superintendent who devised the system). The decision was made on the grounds that the track system violated the constitutional rights of blacks but to nonlegal minds the judge seemed to be intruding a political issue into what was essentially an educational matter.

...Last year teachers distributed materials in all elementary classrooms criticizing welfare reform and organized children to take part in a demonstration. In this instance the action had the officlal approval of the board of education. Thus does politicalization of education reach down the classroom. 3

All manner of politics are apparent in these examples. And all manner of actors are apparent participants. Another example of how politics enters into the schools can be seen in any recent discussion of alternative schools such as the type described by Jonathan Kozol. 4

3ortimer Smith, ed., "The Politicalization of Education," Counc11 for Basic Education, Bulletin, XVII (May, 1973), 1-3.

${ }^{4}$ Jonathan Kozol, Free Schools, Bantam Books (New York: by arrangement with Houghton Mifflin Company, Boston, 1972). 
He discusses the educational environment and strongly emphasizes the alternatives and options available to the students. Kozol discusses this in terms of the cholces available to the students. 5 As an example, if one considers a type of school that offers extreme freedom to develop maximum creativity ${ }^{6}$ in the student by emphasizing crafts and the arts versus a type of school that offers a more rigid traditional curriculum with an emphasis on basic traditional subjects, 7 it is obvious that the subject matter offerings will differ a great deal. Each school has a selection of courses, but they are different In nature. That is, the cholces avallable to the students are perhaps broad In scope, but they are nonetheless limited by the selection. To view this in terms of the teaching of political doctrines, it is concelvable that identical course titles in two separate schools would find the extent of instruction on political philosophy or doctrine completely different. The cholce in each case is apparently the same, but it is obvious that it merely appears so, and is truly limited by the selection.

The broadness of the scope of politics that one has to view when discussing education is further apparent in consideration of a more

${ }^{5}$ Choices being of Iimited number and of a character, both as developed by the nature of the school and community. Also, the choices referred to are in terms of academic subjects offered, activities offered, all in terms of scope, orientation, etc.

${ }^{6}$ The choice of the term creativity is to be construed loosely in this usage. The intent is to make the point of the nature of the alternative program rather than dwell on the definition of creativity.

7 Traditional subjects such as reading, writing and arithmetic. 
recent controversy: the controversy of academic freedom and the role of the teacher in soclety. In the post-World War II era, particularly In the early $1950^{\prime} \mathrm{s}$, loyalty oaths became a controversy in which the courts, lawmakers, parents, teachers and schools became embroiled. A quotation from that period suggests that the matter of academic freedom and loyalty oaths is inherently political:

The present controversy between academic freedom, on the one hand, and loyalty oaths and Congressional investigations, on the other is, unescapably, a matter of politics. It is political because under our system of government we must resort elther to the courts or to the lawmakers for the final resolution of an issue. The Supreme Court of the United States has followed numerous rulings by state courts in holding that a state does have the right to set up qual1fications for teachers and that qualifications may include association through membership in organizations held to be subversive and disloyal. Since the courts have ruled, the next resort is to the lawmakers, which brings us back to the people who elect them, and to 1ssues which can be settled only at the ballot box.

To say that resistance to loyalty oaths and Congressional investigations is not political is to ignore the basic facts of political franchise. Many states already have loyalty oaths and others plan to enact such a law. How will those already on the books be repealed except through political action? How will those proposed be prevented from adoption except through political action? Thus, those teachers who oppose such acts must realize that their actions in opposition, elther directly or indirectly, will be political in use and application. 8

The questions posed in the quotation have since been answered. The courts and the lawmakers have modifled and deleted many a loyalty oath then in existence and the process by which this happened was through the political process in one manner or another. The comments in this

\footnotetext{
8Walton Manning, "Academic Freedom and Politics," Phi Delta
} Kappan, Vol XXIV (June, 1953), 398-99. 
quotation have a timeless quality in one sense: regardless of the state of loyalty oaths or of academic freedom, their intent and existence will ultimately be a function of the state of the political spectrum: the courts, the lawmakers, and finally the people.

Through these examples it becomes apparent that the realm of education is inherently political in its basic nature. The relationship is complex and multi-faceted. Whether one speaks of academic freedom or indoctrination, teacher unions or school board membership, or parent groups or special student programs, the processes and relationships involve the very social order we live in and are inextricably and broadly tied to the political environment which promotes them. The cases which follow display all of the variety which is implied in the previous discussion.

The New Black Citizen in Education

Education and educational financing in Alabama from the Civil War period to the early $1900^{\prime}$ 's provide a fascinating period in which to study the relationship of education to politics and race in the South. After the Civil War, some progress was made to educate the Negro. As race hatreds were exploited in the political arena, the educational gains were gradually lost as the movement to disenfranchise the Negro gained momentum. Alabama's constitution was finally amended in 1901 to virtually disenfranchise the Negro. At the same time, funding for Negro education was drastically reduced with a corresponding increase in white educational funding.

As the trend in Alabama during Reconstruction was from plan- 
tation farming to sharecropping, it was also toward greater industrialization. In 1852 the total state taxes were $\$ 548,340$ of wh1ch taxes on slaves accounted for 41 percent. To provide for schools and state functions during the Reconstruction without benefit of the tax Income from slave holdings, increases in taxes on real property increased to a total of $\$ 1,378,168$. Of this, $\$ 1,171,486$ was from taxes on 1and. Comparisons of ten distinct regions of Alabama in H. M. Bond's, Negro Education in Alabama, for $1852,1870,1880$ and 1890 show a marked growth in the tax base. Much of this can be accounted for through industrialization. 9 As industrial growth accelerated, the burden of taxation shifted to the new urbanizing areas of Mobile, Montgomery, Birmingham and Calhoun County. This shift in tax burden accompanied change in educational policy and political maneuvering which sought the disenfranchisement of the Negro, politically and educationally. Moreover, it helped to solidify the balance of national power ${ }^{10}$ in Alabama (and other Southern states) as well as to "harness the Negro In a socio-political position befitting him as evolved through Southern demagoguery and racism."

\footnotetext{
${ }^{9}$ Horace Mann Bond, Negro Education in Alabama (Washington, D.C.: Associated Publishers, Inc., 1939), p. 133.

10 It must be recognized that the Democrats promoted racism during this period and that the popularity of the measures that they promoted gave that party a certain appeal in Alabama and the rest of the South. It is suggested that the tendency of the South to be largely Democratic is due in large part to the events of the period in discussion.
} 
Although the Enabling Act of March 2, 1819 which admitted Alabama as a state allowed the formation of a public school system, such a system was not attempted until 1826. The first was a school district in Mobile County which had the right to a local county tax and recelpts from fines, penalties and land grant sales for support. Monies derived were used to support private schools primarily in Mobile County of which some went for the education of Negroes. In reaction, the legislature in 1832 enacted legislation to bar the education of Negroes. This drew criticism from Mobile County who as late as 1860 clalmed 114 enrolled "free" Negroes. A general statewide public school system was formalized by the General Assembly of Alabama in 1853 and 1854. With this, sectional disputes arose setting the then richer Black Belt cotton counties against the proposed equalization method of financing:

....It is the old story of the rich county, disliking to ald the educational work of the poor county. In their protest a table is given where it is shown that while 15 of the poorer counties paid $\$ 51,983.92$ in taxes and recelved $\$ 7,598.51$ from the sixteenth section funds, they also received in 1856 for education in addition to the above $\$ 61,281.41$ from the state. On the other hand, while 15 of the wealthier counties pald the same year $\$ 394,262.74$ in taxes and recelved $\$ 52,172.27$ from the sixteenth section funds, they were allowed from the general state tax only $\$ 45,112.18$ in addition for schools.11

During the Civil War era, the mission board and Federal army created a Negro school in Huntsville in 1863. The Freedman's Bureau created two more in Southern Alabama in early 1866 and other Bureau schools were

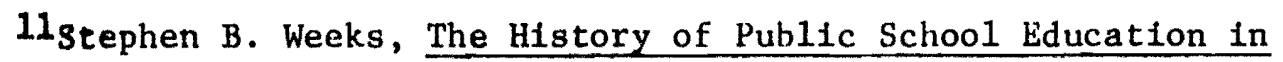
Alabama. U.S. Bureau of Education, Bulletin No. 12 (Washington, D.C. : Government Printing Office, 1951), p. 74 as quoted in Horace Mann Bond, Negro Education in Alabama (Wash., D.C.: Associated Pub. Inc. 1939), 75. 
later opened with a high total enrollment of 9,799 in June of 1867.12

The Reconstruction constitution of Alabama drawn up in $1867 \mathrm{did}$

not specifically call for separate schools but

...the Negro members stated that they wished the 1ssue of separate schools left out of the Constitution because, while they did not want to send their children to school with white children, the threat of mixed schools would remove the temptation from future officials to maintain inferior schools for Negroes. 13

Because the keeping of accurate records of expenditures in this perfod was unusual, attempts to analyze educational costs from one county to another becomes difficult. However, the total monies avallable for schools (not necessarily given to them) through the state decreased to almost nothing by 1875 . Partisan strife between Democrats charging Republicans with a pro-Negro bias and Republicans labeling the Democrats as enemies of the public school system was rampant. It was charged that state support dropped from $\$ 306,872$ in 1869 and 1870 to zero in 1873 and 1874. Although conservatives and Republicans held the office of Superintendent of Public Instruction and other important offices from 1868 to 1874 , the ever-growing Democratic Party gained strength through planks on race and economy in government. This strength overtook the Republican cause in 1875. Bond ascertained the reasons:

12Horace Mann Bond, Negro Education in Alabama (Washington, D.C.: Associated Publishers, Inc., 1939), 82.

${ }^{13}$ Ibid., p. 93. 
It is not difficult to find reasons for the failure of the Republican Party in the State. It was an irreconcilable contradiction founded on the premise of an economic revolution for the former non-slave holding whites and the emancipated Negroes. It could fulfill its revolutionary promise for neither of these two groups. No sooner did another faction of the new northern 1ndustrialism come to terms with the archaic planting aristocracy than the Republican Party collapsed. With no genulne economic program in accord with the natural interests of its two diverse supporters, the party fell a victim to its own internal corruption, contradictions, and the alienation of white voters from its ranks resulting from an appeal to race prefudice. 14

Although the Democrats may have rigged elections and promoted demagoguery in Northern Alabama, full civil and political equality was st1ll legally guaranteed to the Negro by 1875. Apportionment for conventions and state office were based on the total population, Negro and white. As economic power shifted from the Black Belt counties to the industrializing counties, discontent built among the white population for what they felt was inadequate representation for whites and unfair distribution of "white" tax money for schools. White supremacy and economy proved key to maintaining the Democrats in power. Two threats came to the Democrats in this period, from the Green-BackLabor party in 1878 and a pro-education Populist Party called the Alliance in 1889.15 The Allance, a definite threat in the 1892 gubernatorial race, lost to a strong and corrupt Black Belt Democratic organization.

14 Ibld., p. 2.

15 Ibid., p. 129. 
The quest for local white funding for local white schools was heartily promoted by the evolving, white, urban-industrial areas. Attempts to promote local taxation for the white school system were declared unconstitutional as was a similar attempt in 1885 to tax the property of each race separately for the support of racially separate schools. A third attempt which called for separate districts for each race, supported from taxes levied on respective races, was also declared unconstitutional in 1887. Although this move was temporarily prohibited, the local taxation issue persisted as a potential political reform.

The state fund distribution to schools was brought into focus again in the session of 1890-1891. House B111 504 was passed calling for placement of school funds in the control of local authorities to be spent at their discretion. Bond concluded:

As the b111 was intended to aid the Black Belt, it is probable that the white county representatives had made a compromise agreement with the Black Belt, agreeing to let them have the advantage of a diverted school fund from the Negroes if the Black Belt in turn would agree to ralsing the amount of money appropriated by the State for schools.16

The method of distribution of state educational funds at that point had profound effects. The use of Negro teachers in Negro schools increased as funding became less avallable. White teachers who demanded white wages sought employment in white schools at the higher wage scale. This was contrary from the Reconstruction system. Reconstruction educational apportionment was on a per capita basis for

$$
{ }^{16} \text { Ibid., p. } 157 .
$$


Negro and white schools. An example would be a system

...which actually enrolled only from 30 to 40 percent of the Negroes wh1le the percentage of whites enrolling would, in all probability, be much higher. A Negro school in a township might receive $\$ 1,500$ from the state distributive fund for the education of one thousand children of school age. With only three hundred of these children enrolled and with an average attendance of probably less than one hundred, the Negro school could afford a longer term and a better paid teacher than the white school in the same township, where a higher percentage of educables would enro11 and attend. 17

This shift in funds had several effects on Negro education. It shortened the length of each school term and decreased the amount of funds available for facilities. It also dictated an increase in the number of Negro teachers and an equal reduction in the number of white teachers due to the reduced wage scales. Interestingly, no records beneath the county level are avallable for the period following 1891-1892.

The fact that the State Report did not resume printing these data until 1908 is in itself a significant testimony both to the result anticipated and to that immediately obtained.18

Wilcox County provides a coinparison of funding to white and Negro schools. There, a decline in teacher salary expenditure for Negro schools was consistent from 1876 to 1890 and when the records were resumed in 1907, a fifty percent drop from the 1890 level had occurred. From 1876 to 1890 the white school teacher salary expenditure doubled and when records were resumed in 1907 a seven-fold increase was noted. From 1907, both Negro and white teacher salary expenditures doubled.

$$
\begin{aligned}
& 17 \text { Ibid., p. } 104 . \\
& 18 \text { Ibid., p. } 161 .
\end{aligned}
$$


The Alabama constitutional convention of 1901 was called and the order of business was the disenfranchisement of the Negro. In this respect, Alabama followed North Carolina and other Southern states although V. 0. Key ascertained that North Carolina provided for the education of the Negro after disenfranchising him through 11teracy clauses.19 Provisions adopted in the 1901 session were: establishment of a system of public schools separated by race, adoption of a poll tax, establishment of a three mill school fund from the state with a state IImit of six and one-half mills, limiting administrative expenditures to four percent of the distributive fund, establishing the state superintendent as the primary educational officer of the state and prohibiting sectarian schools from receiving appropriations. Two other sections dealt with the University of Alabama and the Agriculture and Mining College. A final but important section provided new school tax provisions including a one mill county tax which had previously been disallowed. H. M. Bond noted: "...A final factor resulting from the Constitution Convention of 1901 was the final disappearance of the Negro as a political power."20 The conclusion of the 1901 consttutional convention marked the end of the Negro in Alabama in a positive educational and political sense until recent times.

${ }^{19} \mathrm{~V} .0$. Key, Jr., Southern Politics, Vintage Books (New York: Alfred A. Knopf, Inc. and Random House, Inc., 1949), p. 208. $20_{\text {Bond, Nlabama, p. } 193 .}$ 
Industrialization -- The Nation Adapts

The shift from formalism in education to a pragmatic childcentered orlentation paralleled the trend toward vocational education. Trade schools and other forms of manual training education provided controversy in education for over forty years. Lawrence Cremin noted that the display of Russian drawings, models, and tools showing the Della Vos methods developed at the Moscow Imperial Technical School to teach the essentials of a technical education through shop training marked the first important showing of such a program. 21 John Runkle proceeded to institute such a program at Massachusetts Institute of Technology in 1876, shortly after his inspection of the Russian system. The combination of massive immigration coupled with rapid industrialization made the importance of the manual training program even more important. But the concept met resistance such as that of President Emerson White of Purdue: "...To teach trades or trade processes was to subvert the proper and primary work of public education." 22 White recognized the coming industrial revolution but felt the machine would relleve men from the burden of craft skills.

There were others for and against such programs. William $\mathrm{T}$.

21 Lawrence A. Cremin, The Transformation of the School, Vintage Books (New York: Alfred A. Knopf, Inc. and Random House, Inc., 1961), p. 25 .

22National Education Association. Addresses and Proceedings (Washington, D.C., 1880), p. 225. White's criticism of the movement as capsulized by Lawrence A. Cremin, The Transformation of the School, Vintage Books (New York: Alfred A. Knopf, Inc. and Random House, Inc., 1961), p. 29. 
Harris, superintendent of the Concord School of Philosophy in St. Louis claimed that education of that nature falled to distinguish between higher and lower faculties in an individual. Proponents of manual training such as Calvin Woodward of Washington University of St. Louls promoted the notion of manual-training in the form of a self-help theme as well as to dignify manual labor. Although the controversy raged, an increasing number of schools began to institute manualtraining in various forms into their curriculums.

As the movement progressed the proponents and opponents became apparent. Businessmen sought "...trade training to free them from growing union regulations of apprenticeships."23 And as the industrial age advanced, the need for vast amounts of trained manpower made the 1ssue more hotly contested. Unions objected, "...to relinquish control over apprenticeship was to relinquish a hard-won right crucial in the struggle for higher wages and improved working conditions."24 Labor by and large objected to the "botch" workmen turned out by the evergrowing numbers of trade schools. The National Association of Manufacturers promoted such schools after its formation in 1896. An Impasse over the place of manual-training and vocational education might well have occurred had it not been for the establishment of the National Soclety for the Promotion of Industrial Education in 1906. As Indicated in its annual proceedings, its purpose was "...to unite

${ }^{23}$ Ib1d. , p. 33.

${ }^{24}$ IbId., p. 36. 
the many forces making toward industrial education the country over." 25 Clearly a political effort, it sought to sway to union opposition toward vocational and manual-training. From 1907 to 1910 special committees for the American Federation of Labor studied the problem. In 1910 they released a report supporting public programs in manua1training and vocational training. Cremin ascertains this as the turnIng point from which "...the question was no longer whether the school would offer vocational training, but how."26

A counterpart to the vocational training education which sought to meet the accelerating industrial age, 27 was rural, agricultura1vocational education. Although the actors were asking for education of a different content, the essence of each was alike. As the urbanizing areas sought manual-training to help fill the expanding industrial job market, the rural interests sought agricultural training to retain those in agriculture who might be "lured" away to the city, industrialization, and higher wage scales. The Populist movement of the $1880^{\prime} \mathrm{s}$ and 1890's enlisted the writings of Henry Wallace and William Rempster Hoard and spirit of agriculture in the agrarian myth.

25 Ibid., p. 39.

26 National Society for the Promotion of Industrial Education, Proceedings of the Organizational Meetings, Bulletin No. 1 (New York, 1907) quoted in Lawrence A. Cremin, The Transformation of the School Vintage Books (New York: Alfred A. Knopf, Inc. and Random House, Inc., 1961), p. 40 .

27 Which this writer considers to be primarily an urbanization phenomena. 
Federal legislation in the Morri1l Act of 1862, Davis B111 of 1907 and McLaughlin Bill of 1909 provided federal assistance to vocational education programs. The growing national stress on preparedness found the National Association of Manufacturers allied with the American Federation of Labor to promote vocational education within the public school. The result of the joint effort was the HokeSmIth Bill which created a committee to ascertain the needs of vocational education. The recommendations of that committee and ensuing legislation produced the Smith-Highes act in 1916. Accepted by businessmen, trade unionists, and educators, it provided for vocational training on a national basis. Thus, the skill orlented adjunct to the common school became a formally accepted part of a great many educational programs.

\section{An Experiment in Progressivism}

In 1842 Horace Mann urged the adoption of a child-centered approach to education in the Massachusetts public schools. After touring schools in England, Ireland, Scotland, Germany, Holland, Belglum and France, he returned to his position of Secretary of the Massachusetts State Board of Education with praise of the "...beautiful relation of harmony and affection which subsisted between teacher and pupils..." in use in Germany. 28 Such an approach to education found much criticism. A group of Boston educators attacked the child-

${ }^{28}$ Charles E. Silberman, Cris is in the Classroom, Vintage Books (New York: Random House, 1970), p. 59. 
centered approach to education saying:

To place the child's needs and Interests first could only threaten 'the welfare, both of the individual and society, by sending forth a sickly race, palsied in every limb, through 1dleness' and determined 'to gratify a morbid thirst for pleasure. 29

To change the schools from the traditional obedience and submisston orientation to a child-centered approach was anathema to many a traditional educator of the day. And of ten the traditional form of education was looked at as a remedy to diminish crime, vice and moral degradation stemming from Ir1sh immigration. 30 While the so-called progressive movement in education found greatest gains from about 1890 to 1919 , examples of such progress in education can also be seen in the Post-Civ11 War era.

In 1873 , aghast at the Inability of students in the local public schools in Quincy, Massachusetts to write an "ordinary English letter" although they knew their rules of grammar, the school board sought changes which would remedy that situation. In seeking out a new superintendent of schools, they found Colonel Francis W. Parker, an Innovative educator, who had been studying pedagogy in Europe for two and a half years. In implementing a system of education in which the children were taught to understand rather than rote Iearn, Colonel Parker evolved a unique combination of teaching skills, materials and methods which became widely known as the Quincy System. From its inception, it faced a constant barrage of critics who claimed the system

29 Ibdd., pp. 59-60.

$30_{\text {Ib1d., p. } 60 .}$ 
to be "...falsely grounded, unoriginal, and extravagant in its claims." Moreover, it was claimed that "...education was being subverted and the fundamentals Ignored."31 And although open criticism was prevalent in the communfty, the opponents of Colonel Parker's system were forced to recognize the successes of the system as the students were tested by an inspector from the Massachusetts State Board of Education. They excelled in reading, arithmetic, spelling and writing.

After leaving Quincy and after a short stay in Boston, Colonel

Parker settled in Chicago to become the principal at Cook County Normal School. According to Cremin it was in Chicago that he formulated his educational theories and then applied them to the practice school of Cook County Normal School. His intent was ...to move the child to the center of the educative process and to interrelate the several subjects of the curriculum in such a way as to enhance their meaning for the child.32

The successes that Colonel Parker had with the students were a matter of controversy. Cremin stated:

...there was sharp and insistent opposition, particularly from Charles S. Thornton, a member of the Cook County Board of Education. After an examination of the school in the fall of 1891, Thornton wrote: 'It is with great regret that I must report that the results indicate desultory work, care1ess, Inattentive, and Idle habits.' Chicago Tribune, November 22,1891, p. 3 . Parker countered vehement1y that

31 Lawrence A. Cremin, The Transformation of the School, Vintage Books (New York: Alfred Knopf, Inc, and Random House, Inc., 1961), p. 131 .

$$
{ }^{32} \text { Ibid., p. } 131 .
$$


Thornton was 111-informed, and 111-qualified to judge, thereby setting off a flurry of charges, countercharges, reports, and rejolners that made continuing copy for the Chicago newspapers during the remainder of the decade. 33

One might assume that the local political situation in "prereformed" Chicago politics may have played a substantial role in the controversy. However, similar changes to education were also being made in Gary, Indlana.

The industrial age continued to enable and demand the extension of educational facilities and programs. With the staggering growth of the steel industry at the turn of the century, Gary, Indiana, with a prime source of water to meet the thirst of the industry, found itself the reciplent of a new gigantic steel mill complex. United States Steel Corporation (U.S. Steel) transformed Gary from a small unimportant town to a booming city of 12,000 . The need for schools to serve the new population mostly immigrants, was immediately seen. WIIllam Wirt, an educator in the progressive mold was hired as superIntendent to devise a complete school system, including curriculum, facillties and concepts of education.

No faclifies which would extend educational opportunities to its students were left out, Including gardens, Ifbraries, gymnasiums, science laboratorles, shops, music facilities and more. The system was to be open 12 months a year with efficient use of the facilities by use of the platoon system, a system by which students would use the facilities on a rotational basis (students in a shop would trade midday with those in a classroom etc.). The system was activity oriented

${ }^{33}$ Ibid., p. 133-34. (Included as a footnote to the text). 
and designed to allow the students to work at a pace suited to each. But elements of the curriculum found disfavor with educators elsewhere. Conversely, Wirt's "Gary Plan" also found acceptance in many districts across the country. Since he had developed the plan, he of ten served as a consultant to districts which wanted to implement his system. Such was the case in New York City in 1917.

Injected into New York City politics in the mayoralty race of 1917, a study was prompted to determine the effect of the system on the children of Gary:

...John Purroy Mitchel, the reform Incumbent, supported the Gary Plan, while John F. Hylan, the Tammany candidate who won the election, attacked 1t. Hylan charged that the plan represented an attempt to economize on the education of slum children rather than a genuine pedagogical advance. And inasmuch as Wirt had introduced released-time religious instruction in Gary, the religious issue also reared its head. 34

The study, performed under the guidance of Abraham Flexner and Frank P. Bachman used the best available achlevement tests to analyze the "products" of the system. Two general conclusions were made by the study group. One, the organization of the school was progressive and more democratic than the traditional school. Two, the actual learning of the students was found to be sub-standard in terms of abilities to spell and perform artthmetic, and lacking in the more formal areas of education. 35

Although the system was found to have many drawbacks, its basic structure was often coples in other districts. And often it was

${ }^{34}$ Ibld., p. 158. (Included as a footnote to the text).

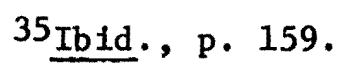


criticized by labor who assoclated it with U. S. Steel and other big business.

The Quincy System and the Gary Plan were only two of the many attempts of the perfod to improve and change the public school. At the same time though, movement from a rigid authoritarian form of schooling to a child centered form of education paralleled the trend toward tradeschool education. These trends and changes, however, were accelerated through the promotion of private experimental schools across the United States. These schools were noted by such characteristics as a project and activity orfentations, informalism and overall changes in disc1pline, curriculum and organtzation from the traditional public school. Known as experimental schools, and often found as a communty school or a teaching school for teacher training in a university, or normal school, the format has more recently been called free schools. In the development of school programs, in curriculum, administration and structure, they have provided examples in each of these areas that have been adopted in part or whole by many public schools in the United States.

In 1896, John and Alice Chipman Dewey opened the "Laboratory School" In Chicago, an experimental school that eventually had 140 ch1ldren, twenty-three instructors and ten assistants. Reported by many authorities of the day to be a fine school with a fine staff, it was orlented to developing methods in teaching, learning and administration. The Laboratory School was used as a model by other experimental schools, some started by former staff and some through knowledge of the successes of the Deweys. It was two decades later 
that John Dewey called the progressive education movement a failure. His experimental school was held in the highest regard of the successes. John Dewey's later writings stated that the student unguided and uncounselled, whether working on projects or activities, does not know best, and that 1 th was this very thing that destined the progressive schools to doom. The lack of proper instruction and teachIng methods for all the good intentions of a school structured for a progressive form of education, could lend to inferior education.

Marletta Plerce Johnson opened the Organic School in 1907 in

Alabama. It was her aim to provide education for students with

... an emphasis that discarded tests, grades, and formal requirements in favor of continuing encouragement for each child to develop his own purposes, use his own abilities to the fullest, and create his own standards for judging the results. 36

Charges by some educators that her school was a "do-as-you-please"37

school, she is said to have responded,

Children do not know what is best for them....They have no basis for judgment they need guidance, control, but this must really be for their good, not merely for the convenience of the adult! Every effort is made to have this conformity merge into and become obedience. That is, to have the child's will to act in harmony with the adult's will. 38

$$
\begin{aligned}
& { }^{36} \text { Ib1d., p. } 150 . \\
& { }^{37} \text { Ib1d., p. } 152 .
\end{aligned}
$$

38 Marletta Johnson, Thirty Years With an Idea, p. 87, as quoted In Lawrence A. Cremin, The Transformation of the School, Vintage Books (New York: Alfred A. Knopf, Inc. and Random House, Inc., 1961), p. 152 . 
During this period many other schools of this nature were organized; Oak Lane County Day School in Philadelphia, Chevy Chase School, Beaver County Day School and others. These private schools had much in common with public progressive experimental schools. Where teaching equipment and supplies were said to have been more available for better instructional use, criticism was also present with regard to curriculum, teaching emphasis and lack of evaluative methods.

Lincoln School was created in 1910 to be operated by Teachers College Columbia University. The curriculum was bullt in a project mode or as Cremin called it, "units of work", or as it is known in some curricula today as modular curriculum. Records kept by the school showed excellent performance by students on school and national exams over the years. Much praise was given the school by alumni but criticism was also found:

Several alumni criticized the school quite severely, claiming that they had not learned to study, that they had wandered aimlessly through loosely planned activities, and that college life had been difficult to settle down to after years of progressive pedagogy. 39

In the public realm, examples of the progressive experimental school are the Porter School in Missouri, started in 1912, and the Winnetka Schools which developed a revised curriculum in 1919 under the superintendency of Carleton Washburne. The public efforts were more geared to teaching large numbers of students with average teachers than small numbers of students with superior teachers. Because of this

${ }^{39}$ Cremin, Transformation, p. 283. 
limitation, programs of the specific nature of the Deweys' Laboratory School are found in rare instances. Elements of these schools, public and private, have been adopted in the public school systems across the nation. And although a renewed interest in the experimental type of progressive schools has been shown in the 1960's and 1970's, many of the same problems remain as well as criticisms.

In a general sense though, broad criticlsm of progressive education centered around the relationship of the student of the education to soclety. The realm of progressive education appears quite broad by merely observing the variety of the specific cases discussed in this section. As such, the role for which the student was taught to play in soclety must have differed to some extent in each school. However, by extracting essays and writings from some of the earlier proponents of progressive education, considerable issue was taken with the works by some critics then and now.

The issue of progressive education and progressive schools ratsed cries of subversion from social critics and critics of public education. By various interpretation of the philosophy of John Dewey at various stages in the development of his philosophies of education, critics referred to his educational thought as promoting group harmony and accord with a subsequent sacriflce in individualism. In recent years additional criticism of Dewey and his diverse writings have appeared:

The children of these 'progressives' have been ralsed upon a diet of unfettered self expression, according to John Dewey's precepts. Not only their own children but the children of millions of Americans have been subjected to these 'progressive' Innovations. American cities, by and large, have been infected by fuvenile delinquency which coincides with the growth of 'progressive' education. The socialistic 
Innovators of the progressive system, however, did not anticipate that the ravages of this method would reach their own offspring. 40

But Dewey's educational thought was complex in nature and can by no means be placed in any one time or place. His thought evolved over a perfod of time and can be seen as relating to the perfod in which written. This fact is not always accounted for in the attacks, even though the essence of his particular statements are often taken and analyzed at face value in the context of modern society, philosophies, and other cultural variations. A more recent criticism charged Dewey and the progressive educators:

...the leftist premise is that children are to be considered as mere reflectors of their environment and should be treated much as robots, not as human beings possessing an individual personality. This entire thesis was designed to cut the ground from under the American principle of the value of the individual...to to change educational emphasis from that of personal independence and freedom to one that teaches that the individual is merely a socialized reflector. 41

Such were some of the more general criticisms during recent discussions of progressive education, but the social commentary of other critics in the same perfod such as that of George Counts drew widespread charges of the same nature.

From Reform to Depression

Just as the experimental schools were important to the develop-

40Veritus Foundation, The Great Deceit (West Sayville, New York: Veritus Foundation, 1964), p. 12 .

$41_{\text {Ibid. }}$ p. 258 . 
ment of a philosophy of education, the political reform movement also left its earmark on public education in this perlod. The publication of the Soclal Composition of School Boards by George Counts in 1927 showed a picture of class blas with an unrepresentative body of "... merchants, lawyers, physicians, manufacturers, and bankers -- coupled with a plea for franker recognition of political and social conflict in the making of educational policy."42 In the same year, Counts wrote a detailed account of political-educational events in Chicago during the tumultuous reform era.

The suspension of the superintendent of schools of Chicago on August 29, 1927 climaxed three and one-half years of debate and discord in the Chicago schools. The events leading up to the suspension are inextricably interwoven into the political fabric found in the urbanprogressive reform era of the early $1900^{\prime} \mathrm{s}$. Three issues predominated in the controversy; teacher councils, the platoon system and the junior high schools. Counts summed up the school-city political background in School and Society in Chicago:

From 1915 to 1923 William Hale Thompson served two successive terms as Mayor of Chicago. The second of his two administrations was marked by a political invasion of the schools of the most shameless order. Mr. Charles E. Chadsey, an able superintendent, was 11legally removed from office before he had scarcely entered upon his duties; the board of education was packed with henchmen of the city hall and the political machine; and the public school treasury was ratded again and again by grafters and embezzlers. Revolting against this gross mismanagement of the public interest, the people of

${ }^{42}$ Cremin, Transformation, p. 226 . 
Chicago in the spring of 1923 elected to the mayor's office a man pledged to keep his hands off the board of education. In the early weeks of the following year $\mathrm{Mr}$. William McAndrew was appointed superintendent of the Chicago schools. He proceeded to administer the system of education with vigor, to claim all the prerogatives of his office to which he was entitled to under law, and to launch a bold and comprehensive program of educational reform.... So bitter was the opposition aroused by these reforms that the personality of the superintendent was made a vital issue in the mayoralty fight in 1927. Mr. Thompson, sensing the possibilities in the situation, attacked Mr. McAndrew on the grounds of Americanism, promised to remove him from office if elected and thus attracted to his camp the discontented elements of the city. 43

The discontent that Counts spoke of developed in various manners which in turn determined the alignments of interest groups for each issue.

Counts pointed out nine areas in which the new superintendent presented reforms:

...an emphasis on business efficiency, concentration on common school education, introduction of a line and staff organization, the abolition of the teacher's councils, the close supervision of instruction, the rating of teachers and principals, the establishment of junior high schools, the Inauguration of the platoon plan and the opposition to political influence in the schools. 44

McAndrew's emphasis on efficiency within the schools had a mixed reception. A time check for all employees requiring new accountability for the teachers drew some hostitility. The teachers in the district viewed this as an infringement on their professional status. The move, however, was lauded by local women's clubs as a means of improv-

43George S. Counts, School and Society in Chicago (New York: Harcourt, Brace and Company, 1928), pp. 6-7.

${ }^{44}$ Ibid. , p. 73. 
ing efficiencies within the schools. In addition, teacher's councils, a form of teacher representation not responsible to school principals were deemed not desirable by the new superintendent. The plan of teacher's councils was originally instituted by Ellen Flagg Young in 1898. When she moved from the superintendency in 1915 their use lapsed. Reinstituted formally again in 1921, they were an established forum for teachers by the time McAndrew became superintendent. The councils had provided a means of communicating teacher recommendations and complaints directly to the administration. But, this structure did not fit in with the new superintendent's organizational plan because of the circumvention of school principals and other administrative staff. In his quest for efficiency he sought to formalize the hierarchy in a vertical arrangement. His refusal to acknowledge the councils and allow them to continue are ascribed as one of the primary means whereby the teaching staff in the city became alienated. The platoon system or Gary Plan as it was known drew further criticism from teachers and also from organized labor. The unpopularity of U.S. Steel in Gary raised suspicions regarding the intentions of U.S. Steel in advocating the plan in that city. Teacher groups were quoted as largely opposed to the plan in Chicago because the program was educationally unsound. The Women's City Club stood behind the superintendent in defense of the platoon system and so did the very important Chicago Tribune. Advocated for its efficiency and better use of facilities, it was none-the-less never adopted in McAndrew's term in office: 
... On June 25, 1924, the Chicago Federation of Labor asked that the board postpone definite action on the 'platoon system' until a public hearing had been held on the question. 45

Likewise, the junior high school program that was advocated by the new superintendent developed opposition from many of the same groups :

... On May 28, 1924, the petition was presented by a citizen's meeting in the Blaine School requesting that the junior high school system be not adopted before the public had had ample opportunity to consider the matter....46

Labor resisted the junior high school and the Women's City Club advocated it. Teachers were split on the 1ssue and the local press predominately supported the plan as did the local Association of Commerce.

The use of intelligence testing and other means of placing and evaluating students roused the ire of labor as "...an invention of the devil to introduce under deceptive bannars a caste organization society into Chicago." 47 organized 1abor's deepseated fear and distrust of big business and industry manifest themselves in this quotation.

Recognizing the political situation in Chicago prior to Dever's election and the subsequent hiring of McAndrew, it is apparent that to create a policy of complete separation of schools and city government

\footnotetext{
$45_{\text {Ibid., p. } 58 .}$

$46_{\text {Ibid. , p. } 58 .}$

47 Ibid., p. 333.
} 
would be to create antagonisms where a shift in power and control

occurred. In this case the new superintendent's opposition to political influence emphasized that very thing. Prior to Dever, scandals in city government through land leasing policy, allocation of contracts for services, assessed valuations on industrial properties, and school textbook and equipment purchase misconduct were the norm. Also, the superintendent had previously been responsive to the local board of education and city council although the latter was not a formal arrangement. When McAndrew refused to bow to the wishes of city hall, new antagonism developed into an undercurrent of discontent.

A visitor from city hall called upon him one day and presented a list of teachers to be promoted. The superintendent, taking up the first name on the 11st asked, 'How is she on apperception?' the visitor had to admit Ignorance.... 'Then,' roared the superintendent, and he is capable of roaring, 'how dare you come in here with such a request? You insult me. 48

Other policles for teachers and student evaluation drew criticism from various elements and added to the discontent. The mayoralty race of 1927 caused much of the discontent to surface. Dever ran a conservative campaign for re-election, primarily noting his accomplishments in office. A typical ad in a newspaper read:

Mayor Dever has taken the schools out of the chaos of corruption in which he found them--following an administration marked by scandal after scandal in the Board of Education. Mayor Dever is the man who found 90,000 children without seats in the schools and who has already provided seats for 72,000 of these children who were being cheated of their birthright by the greed

$$
{ }^{48} \text { Ibid., p. } 265 .
$$


of spoilsmen. Thirty-two more schools are being buflt. 49

The administration marked by scandal that he refers to was that of William Hale Thompson who held the post of mayor two terms previous to Dever. Thompson directed his campaign primarily on school issues declaring that he would oust McAndrew if elected. He alleged that McAndrew was a "...stool pigeon for the KIng of England..."50 and that he advocated un-American teaching such as history slanted toward British interpretation rather than a 100 percent American orientation. Previous to this, discussions in the press regarding pacifism and Americanism found the Chicago Tribune questioning a January, 1926 article in Educational Review called "A Polemometer for History Texts" by McAndrew. In the article, the superintendent had favored removal of pictures "...representing blood and carnage in war, commended the movement for amicable and peaceful adjustment of international disputes...", and he urged the schools to "...promote peace, understandIng and good will..."51 A sertes of editorials in the local press at first questioned his stance in regard to paciflsm and then proceeded to assert its agreement with the superintendent on preparedness first while striving to create conditions of peace. It was on these grounds that Thompson found a receptive audience. Even though the press vindicated McAndrew, the attacks by Thompson coupled with the

$$
\begin{aligned}
& { }^{49} \text { Ibid., p. } 272 . \\
& { }^{50} \text { Ibid., p. } 4 . \\
& { }^{51_{\text {Ibid. }}} \text { p. } 313 .
\end{aligned}
$$


short memory of the Chicago voter elected him to the office of mayor with a plurality of 85,000 votes in a total of $1,000,000$. It was acknowledged that Thompson's flair for the dramatic, his 100 percent American plank and his pose as "...champion of the people against the great moneyed interests..."52 coupled with his opponents lack of dramatics accounted for his overwhelming victory. His first order of business was to oust McAndrew from the superintendency.

By maneuvering positions on the Board of Education, Thompson was able to form a consensus on his policles by August, 1926. McAndrew was suspended by a majority vote of the board of education on "...charges of insubordination and conduct incompatible and inconsistent with, and in direct violation of his duties as superintendent of schools..."53 and the hearing was set for September 29 th. The basic charge was insubordination. The issue was that extra teachers were placed in positions of clerks and administrators whereas they should have been clvil service. Replying to this charge to the board the superintendent made the case that i.t was merely a matter of interpretation of the Otis law. 54 Ignoring this reply the hearing proceeded, dwelling on incompatibility and other vague charges. Witnesses were brought in to testify from local organizations and from out of state. By one he was accused of:

\footnotetext{
52 Ibid., p. 273.

${ }^{53}$ Ibid., p. 276

54 The 0tis law will not be dealt with here as it is suggested that the heart of the issue was the need and reason for the
} disciplinary action. 
...being a member of the English Speaking Union, of recommending a number of unpatriotic history textbooks for use in the city schools, and of urging teachers to attend certain courses given by members of the University of Chicago faculty and containing dangerious un-American doctrines. 55

On November 20,1926 McAndrew declined to be a party to the hearing thereafter. Stalling until the superintendent's term was officially up, there was no longer any need to pursue the issue to the courts: Thompson's pledge was fulfilled. The new mayor did however continue to make recommendations to the board of education regarding curriculum changes and the altering of history texts to a more "American" viewpoint.

The aftermath of the McAndrew affair proved to be a situation quite unexpected by those who joined to force superintendent from the Chicago schools. In 1928, local property owners, ...as a protest against the upward boost given taxes by the city's popularly elected assessor, declared their first tax holiday. 56

The lack of income soon depleted the previous ample funds held by the Board of Education. The c1ty generated a citizens committee to sell tax warrants. Over $\$ 76,000,000$ were sold but were soon used up. The depression economy hit the city and the schools to further compound the financlal exigency. The next mayor, Anton V. Cermak paid teachers with negotiable scrip but was later prohibited from doing so by court Injunction promoted by the Chicago Teachers' Federation. The

55 Ibid. , p. 277.

56"The P11ght of the Chicago Schools," editorial, School and Soclety, XXXVII (May, 1933), 578. 
teachers were simply not paid after this. The new mayor then proceeded to form a non-partisan citizens' comnittee which proposed legislation known as the Kelley Bill. Readily passed, it

...almed to take the assessor's office out of politics by doing away with a popularly elected assessor and dividing his powers between three non-political persons appointed by the governor. 57

With the reform of the very political office of assessor, the funding of Chicago schools sought to avold the irregularities that had plagued Chicago for many years.

During the same period the Atlanta schools were undergoing similar financial trials. There the taxpayers League of Atlanta attacked night schools, Negro schools, kindergartens, music, art and teachers' salarles. 58 In addition, wealthy real-estate owners and businessmen joined to attack the schools on the basis of economy. Although further data is not available to this writer, increased taxes and the state of the economy appear to have triggered the attacks.

The Red Scare-Post-World War II

The post World War II era saw an Increasing amount of criticism of public education across the United States. Using the Education Index as a guide, under the heading of Public Schools-Criticism, $C$. Winfield Scott and Clyde M. Hill in Public Education Under Criticism,

57 Ib1d., p. 578.

${ }^{58}$ A History of Freedom of Teaching in American Schools, Part XVI Report of the Commission on the Social Studies American Historical Association, Howard K. Beale, Chairman (New York: Charles Scribner's Sons, 1941), p. 265. 
used the number of entries in this section as a gauge of the amount of ferment and attack that public education experiences. 59 They noted a range of entrles from three to ten from 1942 to 1948 . The number Increased to 13 in 1949 and was 12 in 1950 with a sharp increase to 35 in 1951 and 49 in 1952. Additional checking showed the total for June, 1953 to May, 1955 to be 58; June, 1955 to May, 1957 to be 21 and June, 1957 to June, 1959 to be 20. A further decline to below ten entries per year since then was evident.

One example of criticism of public education programs can be found in Denver. It experienced critcism of 1ts public schools from late 1949 to 1951. The president of the local Parent-Teacher Assoclation, Mrs. Joseph D. Sitton, on October 30, 1949, clatmed that ...Denver's public schools were emphasizing 'progressive education' to the sad neglect of fundamental learning and the harm of the younger generation. 60

The reaction of the PTA Council was to go on record that the statements by S1tton were those of her own and not necessarily the Council. A local committee, the Citizens' Committee for Improvement of the Denver Public Schools, was formed. Mr. Cyril Reed, a former teacher, was elected to head 1t. And although Sitton had not placed the blame of the system's deficiencies on the superintendent, Dr. Oberholtzer, the new group did. This view of education was construed by the

${ }^{59}$ C. Winfield Scott and Clyde M. Hill, Ed., Public Education Under Crit1cism (New York: Prent1ce-Ha11, Inc., 1954), p. 3.

60 Lawrence Martin, "Denver, Colorado," The Saturday Review of Ltterature, September 8, 1951, pp. 9-10,31., as reprinted in C. Winfleld Scott and Clyde M. Hill, ed., Public Education Under Criticism (New York: Prentice-Hall, Inc., 1954), pp. 303-309. 
Citizens' Committee from some of his former statements:

...education should aim at 'developing the individual

effectiveness of the student... and molding an entire

population into a desirable pattern of group behavior.'

As the Cltizens Councll proceeded to allege that

...Denver's elementary and high school pupils were being grossly defrauded of their rights to a sound education in reading, writing, and arithmetic. 61

The controversy gained momentum and more anti-school publicity developed.

A national organization, National Counc11 for American Education, headed by Allen A. Zo1l, an extremist promoter, descended upon Denver to plead that progressive education sought to convert American school children to Communism and Socialism. In 1950 , certain members of the Citizens' Committee realized the nature of the attacks intended by the group. Immediately they chose a new president, a conservative airline executive with school children. The tactics of the organization changed and became more cooperative. Meeting with the superintendent, the Citizens' Committee sought answers to questions on curriculum and methods. Concurrently the superintendent undertook a professional survey of the schools and citizen reaction to them and an extensive evaluation and testing program of the pupils. The survey found support and suggestions among the public. The evaluation program found many strengths and some weaknesses. Recommendations were made to the school board.

$61_{\text {Ibid. , p. } 312 .}$ 
In the spring of 1951, an election was to be held with two seats open on the school board. Interested local citizens, fearing the radical elements of the Citizens' Committee, promoted the candidacy of two prominent members of the community. Crediting the fair press the Denver Post gave the school issue, the two citizens' candidates were elected with ease. The positive approach of the superintendent, the reaction of the press and concerned citizens promoted a reaction toward strengthening the Denver schools.

Another example can be found in Port Washington, New York, where rapid growth of the suburban area created a demand for school building programs and resultant tax increases. The issues at Port Washington created a perfect breeding ground for financial and social discontent, even to the point where Allen Zoll of the National Council for American Education could proclaim the Communist menance. Fred H. Johnson charged the school district was spending money on "...unnecessary extravagance and the frills and fads of progressive education."62 An allied member of Allen Zoll's organization, he sought to secure defeat of a pending bond issue. Although the bond issue passed on February 23, 1950, the slight margin of victory did not end Johnson's fight.

A school board election in May found Johnson's candidates successful in placing two persons on the board. The Education

62Louls Enge1, "Port Washington, New York," The Saturday Review of Literature, September 8, 1951, pp. 6-7, 25-26. as reprinted in C. Winfleld Scott and Clyde M. Hill, ed., Public Education Under Crit1cism (New York: Prentice-Ha11, Inc., 1954), p. 307. 
Assoclation of Port Washington promoted talks such as "our pink-tinged textbooks" and then Mr. Lewis Haney wrote his column in the Hearst chain, an article entitled, "Smoking out the Reds". Charges and countercharges prevalled and all the while construction costs escalated and the building program was at a standst111. A censorship drive was undertaken with 1ittle reaction from this point: it was a matter of time until the radical issues were settled down for serious and sensible consideration by the voters.

Another example can be found in Eugene, Oregon. It experienced criticism of its public schools by a citizen's group, the Parent's Counc1l who constructed a 11st of demands; more emphasis on the fundamentals of schools, the "three R's", history, 1iterature, solid content sciences; more discipline inside the classrooms; promotion and fallure based on rigid grading, with a system of report cards easily interpreted by parents; and less learning on audio-visual aids and other "entertainment" devices. 63

The demands of the Parent's Counc1l were answered by the formation of a Lay Committee on schools appointed by the school board. Recommendations were made by the Lay Committee after a period of study. They dealt with the areas of criticism and sought to upgrade the curriculum and policies of the schools. In answer to the Lay Committee report, Mrs. W. T. Wood of the Parent's Council responded,

63W. M. Togman, "Eugene, Oregon," The Saturday Review of Literature, September 8, 1951, pp. 10-12., as reprinted in C. Winfield Scott and Clyde M. Hill, ed., Public Education Under Criticlsm (New York: Prent1ce-Hal1, Inc., 1954), p. 316. 


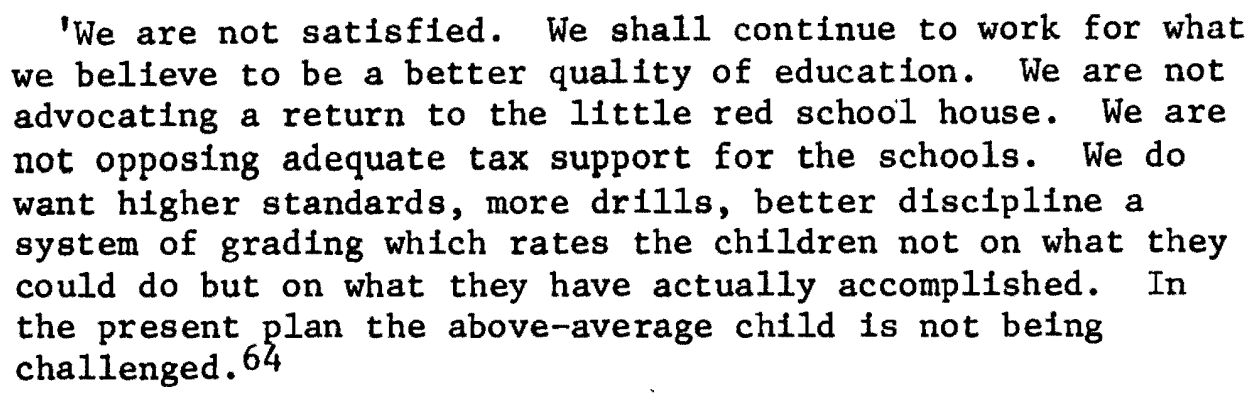

Although both the Lay Comittee and Citizens' Committee continued to operate through 1953, the bond issue of that year was successful, allowing construction of much needed facilities. The dissent in Eugene proved to be constructive. Other school districts around the country found considerable difflculty in settling their local school issues. Such was the case in the late 1940's when the Pasadena School District was racked by organizational and fiscal turmoll and debate on the quality and nature of the education being provided. It began with the hiring of a new superintendent of schools in April of 1948, developed through interaction of various interest groups and ended with the resignation of the superintendent at the request of the school board in November, 1950 and ultimately with a citizen school survey completed in March of 1952.

Dr. Willard Goslin was hired by the Pasadena Board of Education when the former superintendent of 20 years, Dr. John Saxon, did not seek to retain that position. Goslin was hired with the full knowledge that he sought a free hand in evolving a school system organization capable of serving modern educational needs. His letter

${ }^{64}$ Ibid., p. 317. 
of acceptance detalled those conditions to the Board and in essence called for a minimum level of autonomy for his administration. Although the school system as evolved by Saxon was well thought of nationally, 65 large increases in population during and after World War II were not met by expanded educational facilities. Needed changes in facilities and staff provided the new superintendent with immediate problems.

To meet the challenge of revitallzing the Pasadena school system he first set out to reorganize the administrative staff. Of the former staff one top level aide died and two retired within the first year. Goslin brought in two aldes from outside the Pasadena system and filled the third from within. Other top appointments were from within the system by promotion. Insofar as teaching staff were concerned "more new appointments were made in the first two years of the new administration than in the preceding decade."66 of the 1200 personnel certified to teach, over one quarter were still within the three year probationary period. Recognizing the newness of his organization, Goslin took steps for staff training and problem solving, and some of his approaches to these were later subjected to public criticism.

He proceeded to establish the "core system" Into the high schools

65The Pasadena Story, National Commission for the Defense of Democracy Through Education, John W. Davies, Chairman (Washington, D. C.: National Education Association, 1951), p. 13. "The Records of an excellent testing program over a perfod of 19 years showed solid achievement."

${ }^{66}$ Ib1d., p. 12. 
whereby the students would be with a "core" teacher for two hours plus his other classes rather than merely with each teacher for one hour each. He also instituted a discussion group format for problem study by the staff. Through this means he sought feedback and unity within the district. He later added a summer workshop for staff with guest speakers prior to the start of each school year. Goslin Indicated the core system demanded excellent teaching capabilitles, and this along with the newness of the teaching staff, called for in-service training to develop those capabilities. The first year Dr. William H. Kilpatrick was invited as the guest speaker to the summer workshop. By administration standards it was an extremely valuable session and Ironically it was the very first workshop that prompted many of Pasadena's conservative citizens to be wary of Willard Goslin; "It was being whispered around Pasadena that Kilpatrick's five days of lectures were indirectly designed to undermine the native patriotism of Pasadena's youth."67 Association of Goslin's programs and policies with Kilpatrick the educator-philosopher and John Dewey gave focal points for attacks by patriotic interest groups.

To accommodate the need for expanded facillties, a five million dollar bond issue was proposed within the first two months of Gosiln's arrival at Pasadena. It passed handily and preparation was made to Implement a building program. Here one of the first signs of conflict became apparent. Previous zoning had allowed attendance of certain

67Dav1d Hulburd, Th1s Happened in Pasadena (New York: Macmillan Company, 1951), p. 54. 
students from so-called neutral zones in the schools of their choice although others could obtain permission by obtaining a doctor's certificate. With the passage of the school building program, the choice of new zoning and school locations became of prime concern to the citizens of Pasadena. Goslin's plan was zoning based upon standards of distance and safety. Although the bond issue was passed during Gosiln's first two months in office, the new rezoning plan was not presented unt11 Apri1 of 1950 . The timing of the plan coincided with other events to produce a state of turmoil.

Increases in enrollment even during the 1948 to 1950 period demanded even further Increases in teaching staff to allow full operation of the elementary programs. This necessitated asking for a raise in the tax $11 \mathrm{~m} 1 \mathrm{t}$ of approximately $\$ .30$ per $\$ 1000$ assessed valuation. In asking, the administration recognized that "by 1950 , Pasadena property values had risen some 79 percent since 1940, and state ald had risen in the same perlod, however enrollment was up 40 percent and the cost of doing business was up 111 percent."168 An election was proposed by the administration and approved by the Board of Education.

During the preceding months Goslin was called to speak before the Pasadena Chapter of Pro-America. In his talk a question regarding Federal ald to education arose and he responded, "I approve of Federal aid to education but I do not approve of Federal control of

${ }^{68}$ IbId., pp. 64-65. 
Education."69 This 1ed Pro-America to oppose Dr. Goslin's programs.

James B. Conant stated,

Among the charges hurled at Mr. Goslin by the Pasadena unit of Pro-American and others who led the attack were his associations with W. H. Kilpatrick and the 'Columbia cult of progressive educators,' and his support of a program alleged 'to sell our children on the collapse of our way of 11fe. 170

Another citizen group, the School Development Counc1l was formed in the previous school election to run two candidates for office in opposition to what they considered two "Socialist" candidates. A1though their candidates were unsuccessful, the "Soclalist" candidates were also defeated. Their organization appeared dormant unt 11 the "federal ald to education" issue developed. It was at this tIme that the School Development Council coalesced into formal opposition to Goslin and his policles. The National Education Association described their tactics:

...Educational terms loosely defined to Include anything objectionable, were used as political slogans; that Dr. Goslin's Interest in camping, the United Nations, and better human relations were labeled subversive and attempts to indoctrinate children in communism; that the schools were described as godless institutions which falled to teach the $3 \mathrm{R}^{\prime} \mathrm{s}$, were lacking in discipline, and were actively engaged in undermining parental influence. 71

${ }^{69}$ Ib1d., p. 61.

70 James B. Conant, "The Superintendent was the Target," in Public Education Under Criticlom, ed. by C. Winfield Scott and Clyde M. Hill (New York: Prentice-Hal1, Inc., 1954), p. 101.

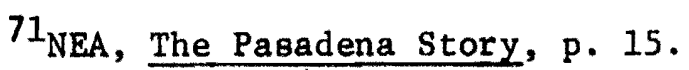


Opposition to the tax plan was evident through attacks by Pro-America and the School Development Council. Also, Sons of the American Revolution, homeowner's associations, the real estate board, retired people's groups and many business groups opposed the tax increase. Of the local press, one major newspaper was against $1 t$ and a second did not discuss it to any degree. Goslin had not endeared himself to either newspaper because of his apparent aloofness which was defended as a very busy schedule and his natural formal business attitude in administration. The Chamber of Commerce, Parent-Teacher Association and the Pasadena Education Association favored the tax increase. A1though the election was asked to be deferred to a later date by the School Development Council, it was kept as scheduled and was defeated in a resounding 22,000 to 10,000 vote defeat on June 5, 1950 .

Since the business of the schools had to proceed, Gosiln planned budget cuts as necessary to operate within the new budget restraints while the Pasadena Education Association hired John B. Knight Company to conduct a public opinion poll to determine how the citizens felt about public education in Pasadena. The results were generally "that the public in Pasadena approved of the school program in general, even though many people belleved that more emphasis should be put on fundamentals." The survey also polled public opinion reaction to the tax Increase proposal.

They showed that the people generally were voting against a tax Increase; only 10 percent were voting against progressive education, and less than 5 percent indicated 
a lack of confidence in Dr. Goslin and the Board. 72

At the same time, the Board of Education had to decide how to resolve the question of the overall program of education in Pasadena.

A citizen's group demanded that a complete survey be taken of education in the Pasadena district. This was agreed to and a twelvemember comnittee was appointed including proponents and opponents of the defeated tax measure. The study was begun but before it had reached any conclusions the board moved to act on the stand that Goslin had taken to them, that if at any time they felt he had become a handcap to the schools, his resignation would be avallable. The School Development Council and a social group of influential downtown businessmen called the Overland Club stated that they would not support the next tax plan if Goslin remained as superintendent. Under these and other pressures the board conceded in a November 7, 1950 meeting that they would ask for their superintendent's resignation. Ignoring letters of support from 194 teachers and principals and recognizing one letter from a central administration official charging that the support letters for Goslin were signed under duress, a telegram was composed asking for his resignation. Cited were divisions between the teaching staff and also great conflicts within the community which could only be settled by his resignation. A portion of the telegram read:

${ }^{72}$ Ibid., p. 17. 
In our opinion the main controversy in Pasadena settles Itself around you as an individual and therefore it becomes our very sad duty to suggest to you, in accordance with your own statement to the board that if the situation became untenable you would volunteer to step out, that you resign because we no longer feel that the situation can be resolved. 73

Recelving the telegram while in the East, Goslin refused to reply to the confusing telegram other than in person. There were explanations to be given, and resignation details and severance payment to be agreed to. While awaiting a board meeting where such a formal resignation would be tendered, the California Senate Committee on Education decided to hold hearings to investigate the alleged subversive activities which had been taking place in the public schools. Goslin's affiliation with UNESCO, the National Conference of Christians and Jews, and the Pasadena Education Association were alleged to be subversive. These latest events merely assured the resignation of Goslin which was formally accepted amid cheers from his supporters at the local board meeting on November 21,1950 . As his replacement, a local principal was appointed to the position of acting superintendent unt1l the school survey could be completed. 74

The Roots of Public Education

Education in the United States in the 1800 's maintained the

73 Hulburd, Pasadena, p. 125.

74Joseph Brandt, "Tlis Too Happened in Pasadena," in Pub1ic Education Under Criticism, edited by C. Winfield Scott and Clyde M. H111 (New York: Prentice Ha11, Inc., 1954), pp. 318-322. The Survey was completed in March of 1952. Comments on the findings by Brandt are included. 
prominent character of Protestant nativism. And although deepseated distruct of Catholics was found on many social fronts, the realm of education provided a focal point for the Protestant-Catholic dichtomy. John Higham in Strangers in the Land cited the reasoning for the existence of the Protestant nativism:

One reason lay in the character of American institutions. Catholic traditions continued to look dangerously unAmerican partly because they did not harmonize easily with the concept of Individual freedom imbedded in the national culture. Americans regarded political liberty as their chief national attribute and supreme achievement. Observing the authoritarian organization of the Catholic church and 1 ts customary association with feudal or monarchical governments, they were tempted to view American liberty and European popery as Irreconcillable...

Nativists, charged with the protestant evangelical fervor of the day, consldered the immigrants mintons of the Roman despot, dispatched here to subvert American institutions. 75

Just as American soclety maintained a Protestant nativist posture, the evolving domain of public education did even more so. In his 1875 address to Congress President Grant stressed the Importance of "...a constitutional amendment forbldding the appropriations of public funds for denominational schools."76 In 1884, the Third Plenary Counctl of the Catholic Cburch "...dedicated 1ts hierarchy to a prompt expansion of parochial education."77 In 1887 the American Protective Associ-

${ }^{75}$ John Higham, Strangers in the Land, Atheneum (New York: by arrangement with Rutgers University Press, 1972) p. 6.

${ }^{76}$ Ib1d., p. 29.

77 Robert H. Wlebe, The Search for Order, The Making of America (New York: H111 and Wang, 1967), p. 44. 
ation (APA) was formed under the leadership of Henry F. Bowers:

The A.P.A. came out of the fevered Imagination of Henry F. Bowers, who directed it for six years. Bowers, a deeply pious, slightly paranold, middleaged widower, saw Cathollc conspiracles everywhere. A self-taught lawyer he blamed his own educational deficlencies on a subversive Jesuit conspiracy against the public schools of Baltimore during his youth. Consequently he had the school question uppermost in mind. 78

Another group, the National League for the Protection of American Institutions, was formed in 1889. It pursued passage of a constitutional amendment against sectarian appropriations of public funds and worked to end the system of federal grants to Indian mission schools.

An early example of the controversies over funding of sectartan schools took place in New York City in early and m1d-1800. There the Public School Soclety, founded in 1805, recelved state money to provide free public education to the poor and in-need. In 1820 the Bethel Bapt1st Church opened a non-denominational school and was pledged state funding. At the objection of the Public School Soclety which was chartered to "...teach the sublime truths of religion and morality contained in the Holy Scriptures,"79 the c1ty council cut off funding to the Baptists and denied allocation of public funds to any religious society. The Roman Catholic Benevolent Soclety asked for funding for their Orphan Asylum School, it was allowed; the

\section{${ }^{78}$ Ib1a. , p. 62.}

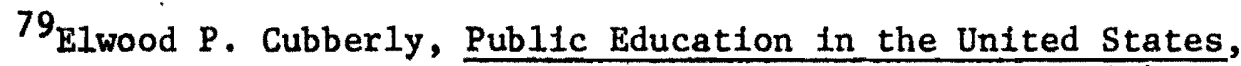
(Rev. and Enl. Ed.; New York: Houghton-Miffiln Company, 1947), p. 236. 
Methodists applied for funding for a similar program, it was disallowed. The Catholics asked for division of the city school fund and when refused, they appealed to the state legislature. As an ally, the Scotch Presbyterian Church supported the Catholic position while the Public School Soclety gained the backing of the "...Methodists, Episopalians, Baptists, Dutch Reformed and Reformed Presbyterians..."80 in the opposition of dividing funds. The state leglslature in 1842 declded the question as they created the City Board of Education which was to create "...real public schools..." and which was to see that "...no portion of the school funds was in the future to be given to any school in which 'any religious sectarlan doctrine or tenet should be taught, Inculcated or practiced. "'81

In 1838 and 1839 Massachusetts was experiencing attacks on its public school system because it had adopted a non-sectarian attitude on textbooks and teaching. E. P. Cubberly noted:

Mr. Mann stood strongly for such a conception of public education and being a Unitarian, and the new State Board of Education being almost entirely. liberal in religion, a series of attacks was launched against them, and for the first time in our history the cry was raised that 'the public schools are Godless schools'.82

These attacks were attributed to

Those who belleved in the old system of religious instruction, those who bore the Board or its Secretary personal 111-will, and those who desired

${ }^{80}$ Ib1d., p. 237.

${ }^{81}$ Ib1d., p. 237.

82 Ibid., p. 233. 
to break down the Board's authority and stop development of the public schools....83

Personal assults on the character of Horace Mann were made by the Reverend Mr. Smith, pamphlets were published and distributed, and letters attacking him were placed in the Boston Recorder. It was claimed that Mann and the board of education were

...trying to eliminate the Bible from the schools, to abolish correction, and to 'make the schools a counter poise to religious instruction at home and in Sabbath schools.'

In reply to these and other accusations, Mann published a lengthy reply "...with a scathing arralgnment of the man as a professed mintster of the Gospel. "85

It was controversies and situations such as these that occurred time after time and which over a long period of time changed the basic character of education In the United States from a sectarian to a nonsectarian form. It was an Americanizing form which replaced the former sectarian form. The vast migrations into the United States sought a medium to promote their absorption into the American social order while the old stock "encouraged" 86 the newcomers to assimilate.

${ }^{83}$ Ibid., p. 233.

${ }^{84}$ Ib1d., p. 235.

${ }^{85}$ Ibid., p. 235.

${ }^{86}$ The encouragement was found in many forms, formal education, discrimination etc. Any discussion of Americanization would describe this encouragement. 
The common school had the ability to promote concerns for the new and growing local and state government, while inspiring alleglance and patriotism to the new order. There were also utilitarian concerns which could be met by the common school, principally that of educating the masses to fulfill the needs of the new evolving industrial order.

Dare the Schools Build a New Social Order?

The social order in the United States evolved through complex industrial growth, geographical expansion, years of immigration and rapid urban growth was the focus of sharp debate as the Great Depression made its manifold effects felt among the general public. Richard Hofstadter noted that the New Deal under Franklin Roosevelt sought to "...make use of the machinery of government to meet the needs of the people and supplement the workings of the national economy." 87 If one interprets the earlier trend in progressivism and populism as restorative as Hofstadter does, then the New Deal programs by Roosevelt might be viewed by some as "...an outrageous departure from everything they had known and valued, and so could interpret it only as subversion or as the result of overpowering alien influences. 88 The depression itself generated profound debate on the future of the country and the goodness or badness of government. Closely paralleling these discussions in and out of government, educators

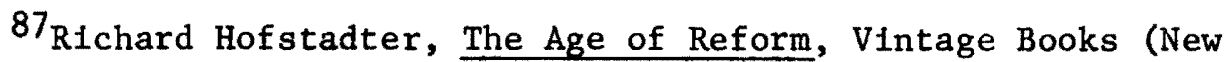
York: Alfred A. Knopf, Inc. and Random House, 1955), p. 302. ${ }^{88}$ IbId., pp. 303-34. 
posed the question of what was the relationship of education to be to the evolving soctal order and what changes in education might be desirable. In 1922, George Counts pub1ished The Selectlve Character of American Secondary Education which began his long career as soclal and education critic. In this book, he directed his inquiry to inequities in race class and ethnicity. Later, he published The Soclal Composition of School Boards and in 1928 published School and Society In Chicago: Lawrence Cremin called the first a "...scathing critique of class blas in American school board membership... 189 and the second analyzed the firing of a prominent Chicago school superintendent for political reasons. Advancing his social critiques on a broader scale he wrote Secondary Education and Industrialism in 1929. It was this volume that he later reconstructed into an address to the Progressive Education Association (PEA), and published as Dare the Schools Build a New Soctal Order? in 1932 .

It was this man through his "dare" that challenged educators to reconsider their role and to reevaluate the role of education in the American social order. He charged that education was "... In the grip of conservative forces and is serving the cause of perpetuating 1deas and institutions suited to an age that is gone. "90 He charged that "the weakness of Progressive Education thus lies in the fact that $1 t$

${ }^{89}$ Cremin, Transformation, p. 226.

${ }^{90}$ George Counts, Dare The Schools Bufld a New Soclal Order?

(New York: John Day Company, 1932); p. 5 . 
has elaborated no theory of social welfare, unless it be that of anarchy or extreme individualism."91 His charges alleged that the upper middle class had gained control of progressive education and were not responsive to the drastic transformation of society. What he sought was a redefinition of the role of progressive education:

If Progressive Education is to be genuinely progressive, it must emancipate itself from the influence of this class, face squarely and courageously every social issue, come to grips with life in all of its stark reality, establish an organic relation with the community, develop a realistic and comprehensive theory of welfare, fashion a compelling and challenging version of human destiny, and become less frightened than it is today at the bogies of 'imposition' and 'indoctrination'. In a word, Progressive Education cannot place its trust in a child-centered school. 92

What he was after was a form of education that would question the politics, the morals and religion of the existing social order. And the ultimate 1ssue was

...the issue of the control of the machine. In whose interests and for what purposes are the vast material riches, the unrivaled industrial equipment, and the science and technology of the nation to be used? 93

The answer given by Counts was "...the promotion of the welfare of the great masses of people. 194

The reaction to Count's speech to the PEA was ecstatic. In response, he was appointed chairman of a Committee on Social and

$91_{\text {Ibid., p. } 7 .}$

92 Ib1d., pp. 9-10.

93 Ib1d., p. 43.

94 Ib1d., p. 43. 
Economic Problems. But the problems of definition and direction began to mount and reaction to his committee's proposal when finally completed was mixed. Branded as too radical, it adopted alms quite similar to those he proclaimed in his earlier speech:

'It should aim to foster in boys and girls a profound devotion to the welfare of the masses, a deep aversion to the tyranny of privilege, a warm feeling of kinship with all the races of mankind, and a quick readiness to engage in bold soctal experimentation.' 95

Cremin concluded what the effect of the report might have been on the PEA; "...It branded the stigma of radicalism on the PEA, 1ike it or not. $" 196$

Rejecting the philosophy of Counts, the PEA appointed a new Committee on Educational Philosophy in 1936. In 1938, another committee was formed, one which sought a philosophy of education somewhere between the extreme child-centered and extreme social-reformist position of Counts. The report is said to have generated confusion and misunderstanding and was consequently not adopted. By this time, critics of progresstve education were increasing while at the same time membership was dropping. In attempting to develop a more distinct philosophy, one which would unify the reform elements, the PEA gradually "... weakened the movement in the long run by narrowing the

95 The Committee of the Progressive Education Association on Soctal and Economic Problems. A Call to the Teachers of the Nation (New York, 1933), p. 5, as quoted by Lawrence A. Cremin, The Transformation of the School, Vintage Books (New York: Alfred A. Knopf, Inc. and Random House, Inc., 1961), p. 29.

96 Lawrence A. Cremin, The Transformation of the School, Vintage Books (New York: Alfred A. Knopf, Inc, and Random House, Inc., 1961) p. 264 . 
base of its political support."97 For while the PEA sought a philosophy, the NEA promoted vocational training and health education and the AFT sought tenure laws for teachers and pursued academic freedom. Cremin provided the ephitaph for the PEA, "...1t simply failed to comprehend the fundamental forces that move American education." 98

\section{The School-Charges of Indoctrination}

Although the question of the purpose of the school in American soclety and the content of that education have promoted controversy for many years, attacks in recent years in the area of "political" education have become more frequent. World War II, the Korean Confllct and the perfod between fostered suspicton of the "Red" menace. As discussed previously this led to attacks in part in such school systems as Pasadena; Port Washington, New York, and Denver, Colorado. A primary component of the attacks was the textbook and of course the general course orlentation in which it was presented. In the same perlod and after, research on the effects of these clvic education courses in general was undertaken. The results of this research yleld data which enlightens the charges of some of the attacks in the $1950^{\prime} \mathrm{s}$.

In 1959 , In Brainwashing in the High Schools, E. Merrill Root charged that the United States was losing the cold war. 99 When large

$$
\begin{aligned}
& 97 \text { Ib1d., p. } 273 . \\
& { }^{98} \text { Ib1d.; p. } 273 .
\end{aligned}
$$

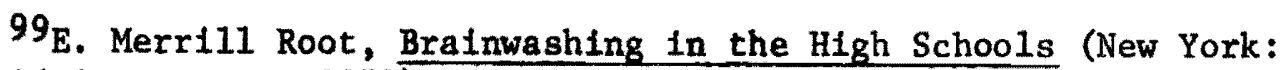
Devin-Adair Company, 1959). 
numbers of U.S. prisoners in Korea succumbed to "brainwashing" he pointed out that

These young men ylelded because they have never been taught to understand, as thelr Communist masters did understand, American politics, American economics, American history, and American ideals. They had a vacuum where they should have had a storehouse of knowledge about the American Revolution, the Founding Fathers, the Constitution, and the nature of our Constitutional replublic.... They were left so nalve and unsophisticated that they had no rebuttal with. which to blow away like a cobweb house the half 11 es and shabby slanders of cynically clever Chinese or Russtans. 100

He charged the educational system, Its teachers and teaching materfals with "failing miserably in getting across the absolute fundamentals of survival in a tense and troubled international soclety."101

In his analysis Root revlewed eleven, then current, textbooks used to teach clvics and government classes in Evanston Township High School. He maintained four basic assumptions: 1) the American Revolution was to set the Individual free to work out his own problems in his own way, 2) the United States is not a democracy but a constitutional republic, 3) the good life comes from the initiative of private man, not government handouts, and 4) the wealth of the nation has been accompanied "by intellectual, religlous, and spiritual freedom."102 His approach charged that those actions of a liberal nature were consistently shown in a very positive light in general and that collectivism was continually referenced in a positive vein. Upton

100 Ib1d., p. 11.

${ }^{101}$ Ib1d., p. 3.

102 Ibid., p. 13. 
Sinclair, Lincoln Steffens and other turn of the century writers were shown as "leftists" or communist orlented by Root. He asserted that the texts were ant1-bustness and ant1-Republican by and large, and he charged that the basic conclusions reached by many of the texts were unfounded (based upon his premises) and that they had no supportive documentation. He clted passages from the varlous texts extensively and alleged their leftist intentions. He concluded:

What American schools need is a thorough housecleaning.

I do not know where, as the housecleaning begins, they w111 Immediately find the new textbooks that they need. I do not know where they will find realistic and revolutionary textbooks in American history -- or in any subject. But I do say that big publishing companies will see to it that schools get these texts when schools 'ask' for these texts.103

Another publication, The Great Deceit was written to show that "...the greatest danger to the Free World today is creeping socialism, ..."104 Produced in 1964 by Veritas Foundation, 1t took broad aim at a variety of issues from interpretation of history, to racism, to Marxism and to education and other areas. In the realm of education charges were made that this leftist orientation began many years ago with the Progressive Education movement:

John Dewey and his socialistic clique on the educational field outlined a plan to sell soclalism under the level of 'progressive education' to teachers, parents, politiclans and most of the colleges and universities in the United states. This was a massive projection to subvert the thinking of an entire nation by means of its educational

${ }^{103}$ Ib1d., p. 263.

${ }^{104}$ Veritus Foundation, The Great Deceit (West Sayville, New York: Veritus Foundation, 1964, p. 1 . 
system. Already the textbook field was heavily infiltrated by leftists. Thousands of teachers were pre-conditioned to accept collectivist ideas as a result of indoctrination in the graduate schools of the nation. Fabian socialist permeation of the literary world had already made soclalistic thinking a fashionable pastime.105

And since John Dewey has been heralded as one of the more influential movers in the progressive education movement, his works and "evolving philosophy" were attacked as promoting indoctrination in a multiplicative fashion: An elistist left group in the university trains teachers and the teachers, textbooks and journalists teach and indoctrinate untold thousands; in doing so the philosophy of the few through thịs process becomes "the modern process of indoctrinating an entire nation."106

The question of polftical indoctrination and effect of teacher upon the students has been explored in much greater depth in recent years as have the areas of clvics and government courses, textbook content and value accumulation and political indoctrination.

In 1968, Kenneth Langton and M. Kent Jennings conducted research In high school civics classes. In the study they attempted to find a relationship between civics courses and political soclalization among high school sentors. From the results of their research they concluded that

...there is a lack of evidence that the civics curriculum has a significant effect on the political orientation of the great majority of American high school students. More-

$105_{\text {Ib1d. , p. } 259 .}$

${ }^{106}$ Ibid., p. 263. 
Over those who are college bound already have different political orfentations than those who do not plan to attend college. 107

In a study of clvic education in three American communities Edgar Litt found that the political role for which each of the three groups were trained for depended on 1ts socto-economic status. He classified the Alpha group as affluent and politically vibrant and concluded that as a group, it was taught civics as a vehicle for group struggle and change (with insights into the political processes). The Beta group, called "lower middle-class", was found to be strong on training in the elements of democratic government with an emphasis on the responsibllitles of cltizenship. The Gamma or "working-class" community was found to not encourage "a belief in citizens' ability to influence government action through political participation."108 And although this difference in role expectation appeared, Litt also concluded that

Comparisons of attitude changes in the schools do not uncover any reversal of beliefs along the five political dimensions that can be attributed to the school's indoctrination. 109

${ }^{107}$ Kenneth $P$. Langton and M. Kent Jennings, "Politica1 Socialization and the High School Civics Curriculum in the Untted States," In The Learning of Political Behavior, ed., by Norman Adler and Charles Harrington (Glennview, Illinols: Scott, Foresman and Company, 1970), p. 185 .

${ }^{108}$ Edgar L1tt, "Civic Education, Community Norms, and Political Indoctrination," In The Learning of Political Behavior, ed., by Norman Adler and Charles Harrington (Glennview, Illinols: Scott, Foresman and Company, 1970, p. 168.

109

Ib1d., p. 167. The five categories are 1) support of democratic creed, 2) political chauvinism, 3) support of political participation, 4) politics as process of power, politiclans, 5) function of politics to resolve group conflict. 
A content analysis by Litt of 27 textbooks in civic education programs revealed

...no substantial differences in references to elements of the democratic creed or in chauvinistic treatment of American political procedures and institutions....110

but that the Gamma texts were bland and filled with descriptive references and the Alpha texts more oriented toward politics and political processes with an emphasis on political group struggles and political power. The Beta group textbooks scored midway between Alpha and Gamma on all counts. ${ }^{111}$

One must ask though who selects the textbooks that are assigned to various clvics classes in each group studied. Do they reflect educators'viewpoints or the viewpoints of those on the board of education? These are questions that can only be answered in these specific instances by Litt, but he suggests that by and large the orlentations reflect the supporting attitudes of community leaders or at the least, the two viewpoints coincide.

In Kenneth Langton's 1967 study of peer groups in Jamaican high schools, a conclusion was made that "heterogeneous class schools appear to be resoclallzing working class students in the direction of hIgher class polftical norms."112 The conclusions of his study make one ask if certain non-formal aspects of the school are not as

${ }^{110}$ Ib1d., p. 165. See table 2.

${ }^{111}$ Ibid., p. 168-9. Methodology for textbook study.

${ }^{112}$ Kenneth P. Langton, "Peer Group and School and the Political Socialization Process," in The Learning of Political Behavior, ed., by Norman Adler and Charles Harrington (Glennvlew, Illinois: Scott, Foresman and Company, 1970), p. 162. 
important or more important in developing attitudes and values than formal aspects. Joe C. Gannis suggested that the structure of the school in terms of authority and decision-making and in terms of the format that the school operates within might well be more instructive to the student of how soclety operates than the formal curriculum itself.113 Current studies in political soclalization tend to confirm that by the age of seven most children have firm attachments to their political communtty. 114 If this is so, one must investigate what other soclalizing influences have such a great influence on the child to create such attitudes by the age of seven -- church, family, peers, press, television and radio...

In viewing the controversy of whether the educational system is collectivist oriented, including teachers and textbooks, one must also know how major a role the teacher or textbook plays in "Indoctrinating" or "Imbuing" a student with political values, and if they do play a large role, do their views differ from those of the community which promotes the school's educational programs. Recent studies in political socialization give perspective to those attacks on education, for it is not merely a question of teachers and textbooks, it is a

${ }^{113}$ Joseph C. Grannis, "The School as a Model of Society," in The Learning of Political Behavior, ed. by Norman Adler and Charles Harrington (Glennview, Illinois: Scott Foresman and Company, 1970), p. 137 .

114 Dav1d Easton and Robert D. Hess, "The Child's Political World," In The Learning of Political Behavior, ed., by Norman Adler and Charles Harrington (Glennview, Illinols: Scott, Foresman and Company, 1970), p. 42. 
matter of many soclallzing agents, the school belng a basic socializing institution but certainly not the only one. The charges were indoctrination and subversion. The textbooks may promote "democratic" government or equalitarian themes, but are these different than what is asked for by the public which supports and promotes education? The question will not be dealt with here for that is a matter for a study itself. The charges are certain to continue but further studies in the area of political socialization will be able more clearly to ascertain the role of education and the schools in the development of an individual's political allegiances and philosophies.

\section{Black and White Education -- Separate and Unequal}

Judicial dectsions in the $1950^{\prime}$ s and $1960^{\prime}$ 's created stresses in public education while attempting to negate the raclal legislation and practices of many years. The civil rights landmark judicial decision in 1954 in Brown vs Board of Education of Topeka signaled the beginning of a slow and tedious process in American Society: the desegregation of the public school, with the informalized and formalized segregation of the North proving to be a formidable as the formalized, stringent segregation of the South.

New York City provides several examples of the elements involved in such controversy. Plans to desegregate existing schools and new schools in the 1950 's repeatedly did not fulf 111 their intended purpose. An attempt in 1956 to integrate a new junior high school (JHS 258) with the support of various integrationist elements, "... the Intergroup Committee, the Urban League, Dr. Kenneth Clark, local 
parents associations, and Labor unions and religious groups..."

falled.115 Alleged support by the National Association for the Advancement of Colored People and half-hearted support by Mayor Wagner could not prevall against school officials, real estate interests, and white and Negro middle-class parent groups. David Rogers also noted that the

Upward Mobile Negroes who had moved out of the BedfordStuyvesant Ghet to to white residential areas did not want their children forced to attend schools with poor Negroes from the Ghetto. They also wanted to Iimit the number of Negroes in their new communities so that whites would not panic and move out.116

Another example is cited where a junior high school (PS 289) was planned for a ghetto location but later located in a white residential area, yet ended up with 90 percent black students. In the planning stages white desegregation groups supported desegregated schools for the entire Crown Helghts area. In that situation though the Central Zoning office declined to allow middle class Negro children who had escaped the ghetto to attend the newly created school.117 The Eastern Parkway area served as an area of demarcation of raclal zones In Brooklyn. The final decision was to locate the school nearby Crown Helghts, largely a white area, but to have it largely attended by blacks. Such controversy marked New York public school system to the 1970's.

Kansas City's Central High School provides an example of controversy within a black school district. The core residential area

116 Ib1d., p. 21. (Included as a footnote to the text). 117 Ib1d., p. 22. 
of Kansas City had been gaining a higher percentage of black residents for a number of years. With the enactment of the Brown decision, Kansas City's Central High became one of the first schools to integrate. The school went from 100 percent white to 50 percent black Immediately. The question became what to do with the school academic standards. In mild controversy, Negro parents threatened to

...raise the political devil if anything is done to make

Central more like the city's other lower-class schools. 118

In response to demands of this nature and complete backing of the Negro community, Kansas City leaders decided to uphold the standards of the old school. A program stressing scholarship, excellence and competitiveness was emphasized. In response to the new program, dropouts ceased to be a problem and a great percentage of the students continued to college ( 40 percent). But as the socio-economic base of the central c1ty continued to deterforate the future of Central High School was open to question. The question of standards was answered in Kansas C1ty with an insistance on high standards. But the question is not always responded to as in Kansas City. Other areas choose to maintain different sets of standards for blacks and whites, not only academically but administratively.

Another case Involving an urban core school involves criticism of David McCrea, principal of Bolse Elementary School in Portland, Oregon which resulted in an official disclplinary proceeding against

118 Martin Mayer, The Schools, Anchor Books (New York: Doubleday and Company, 1961), p. 136 . 
him. On September 24, 1973 McCrea made statements regarding his predominantely black, urban lower socio-economic school that drew fire from angered parents, the National Association for the Advancement of Colored People (NAACP) and the Portland School Board. The Oregonian described his comments and made some observations:

Nine out of ten students are black and a similar majortty is considered educationally deprived.

'The values here are a little different,' explained Jerry Simnitt, the physical education coach who counseled her.' Spontaneous emotion is part of the accepted order with these kinds. You have to tolerate a little more than you would from other kids.'

Bolse staff are accustomed to putting up with occasional outrageous behavior, frequent racy language, and activities which other schools call insubordination.

'The idea of busing white kids in here is unthinkable,' said McCrea. 'They'd get eaten alive.' Boise School has a strong pecking order, in which physical prowness and the ability to socialize according to the rules of urban black culture are the main determinants of status.

Most white students, even those strong enough to defend themselves physically aren't used to the social rituals of a black school -- the dancing, the clothing, the five. Whites may be accepted, but they do not become leaders.

'A white kid cannot excel here,' McCrea said. 'In fact, we've had several requests from white parents to have their kids bused out, which we can't do.'119

For these and other comments, the Portland School Board under the pressure of the NAACP and angry parents, some of whom belonged to the Bolse Citizens Improvement Assoclation, suspended McCrea from hịs 
duties. Ellis Casson, president of the Portland section of the NAACP called McCrea's remarks "vindicative, prejudicial and racist" and called for his removal from office. Superintendent of Portland Public Schools, Robert W. Blanchard, and board member Robert Ridgley agreed with Casson and completely disavowed the principal's remarks," ...but sald they should be a matter of discussion between principal and his Immediate supervisors."120 At the same board meeting Blanchard addressed the board on the Bolse issue:

I would like to be especially candid on another issue. These are times when teachers and administrators under a multitude of pressures and conflicts, occasionally turn their backs on an 1ssue of lesser importance at that particular moment. This is not unique to education. Frequently, in a different context we hear such comments from police officers. Unfortunately, in the life of an individual ch1ld, the 'permissiveness' can create more serlous problems. This is especially true when there are class differences involved. Please remember that such problems also occur at upper levels of Income -- we are all famillar with the outraged corporate executive whose children can do no wrong: Occasionally a teacher can come to believe it. I challenge a11 teachers and administrators this evening to renew their effort to provide consistently the same type of firm, evenhanded discipline and understanding they would expect for their own children. This should be carried out with respect to all students, irrespective of background. I am convinced this is what the parents of this community want....

This is not a blank check to vindicativeness, when developing self-discipline and modifying behavior is the professional preference. But a school or educator that acts rationally w111 be supported. 121

120B111 Keller, "Removal of Boise principal urged over 'racist' remarks," Oregonian, September 25, 1973, sec. 4M, p. 9A.

${ }^{121}$ Robert Blanchard, "Boise School and Related Issues," (address to Portland Public School District Board, Portland, Oregon, Oct. 1, 1973), pp. 4-5. 
After what was generally accorded as a suffictent apology, McCrea was reinstated to his duties as principal. The event did get a frank appraisal in the editorial section of the Oregonian from the same writer who had initially featured Boise Elementary in his column:

The administrators don't say so but above all they charge McCrea with the capital crime of being controversial. The politics of schooling are clearcut. A principal isn't supposed to say controversial things, at least not for the record. 122

Boise Elementary did get back to a normal operation and the tempers of angered parents simmered down. But the question of busing, black culture within Bolse and education and behavioral standards at the school were not confronted in any meaningful way.

A controversy which developed on a larger scale occurred in 1961 as the result of the publication of a four-part, nationally syndicated, newspaper series regarding the status of Negro educational attainment. A national award winning serles, it drew Immediate criticlsm from Black cltizens who claimed it was unfair and not true, but who later were confronted with the accuracy of the analysis.

In the first part of the series it was suggested that "...the typlcal Negro graduate is less prepared for equality than he was in 1954 -- and perhaps even than in 1863!" In some Florida counties twelfth grade tests from 1954 when compared with tests from 1961 showed this. In 1954, "...18 percent of the Negro sentors were below 99 percent of the whites" with only "...seven percent of the Negroes as

122 B111 Keller, "Beleaguered Bolse principal finds supporters among parents who see deeper problems," Oregonlan, Sept. 30, 1973, sec. $3 M, p . F 3$. 
good as 50 percent of the whites." The same tests in 1961 revealed that only five percent of the Negroes earned scores as high as 50 percent of the whites, while "...half of the Negroes earned scores lower than all but one percent of the whites. And these statistics were from the state of Florida..." which was recognized nationally as having one of the best, If not the best school systems of all Southern States,"123 The article continued to give example after example of how Negroes consistently performed poorly on various testing programs, even those that required the minimum skills of reading and arithmetic.

The second article in the series cited various Northern cities which had improved the educational attainment of the Negro. While not reducing white achievement, significant gains in Negro achlevement were noted in newly integrated Loulsville (even in the st1ll all-black schools), Washington, D.C. and Indianpolis. Again the South was held up to this for comparative purposes with the conclusion that the Southern Negro lagged behind the educational attainment of the Northern Negro. In trying to determine what would account for the differences discussed, the third in the serles concluded that "...the more favorable the economic, cultural, and educational opportunity, the higher the Negroes score on achievement tests." 124 The title of the fourth in the series "Opportunity Opens Doors to 'Spirit"" concluded

$123 \mathrm{Dr}$. Walton Manning, "Education and the Negro," Miami News, Sept. 22, 1961, P. 1A and P. 5A.

${ }^{124} \mathrm{Dr}$. Walton Manning, "Education and the Negro"--"They Gained in the North," Miaml News, Sept. 23, 1961, p. 3A. "In the typical Southern school one to ten percent of the Negro students exceed the national average. In some Washington, D.C., schools, about 40 percent exceed 1t, and in a few Indianpolis Negro elementary schools, the figure is almost 50 percent." 
that Negroes by and large do worse than whites because they have "... less opportunity, and thus less desire, ambition and motivation."125

The Negro did not want to belleve that since the desegregation decree in 1954, that his educational attainment had decreased. But the evidence was at hand, and in the end, the facts prevailed.

Educational Alternatives -- Threat to Tradition?

The educational alternatives so much in controversy in the mid1800 's and then in the early 1900's found renewed conflict in the 1960's. Free schools, open classrooms, alternative schools, middle schools and voucher plans are just a few of those issues of controversy. Prompted by judiclal civil rights decisions in the $1950^{\prime} \mathrm{s}$ and $60^{\prime} \mathrm{s}$ plus other activist movements, stirred by the Vletnam War, inflation and political scandal, these devices, methods and alternatives received criticlsm and praise. Discussion of them can be found in any educational journal or current paperback on the schools. To best display the primary political-education issues at hand though, analysis of specific controversies must be developed.

Jonathan Kozol in Free Schools made a distinction of what free schools are in the context of the free schools in which he has participated in, especially in Boston, versus other forms:

I am, then, speaking for the most part about Free Schools (1) outside the public education aparatus, (2) outside the white man's counter-culture, (3) Inside the c1ties, (4) in

$125 \mathrm{Dr}$. Walton Manning, "Education and the Negro"--"Opportunity Opens Doors to Spir1t," Mlami News, Sept. 25, 1961, p. 1A. 
direct contact with needs and urgencles of those among the poor, the black the disadvantaged, who have been the most clearly victimized by public education, (5) as small, 'decentrallzed', as we can manage, (6) as little publicized as possible. 126

Kozol distinguished his free school from the public realm. He also made a definite distinction in intent: his free school looks to basics; arithmetic, reading and writing. In his own words:

It is not to speak of doing 'our own thing,' but rather to do one thing that really matters and can make a visible difference in the lives of our own brothers in the streets that stand about our school.127

In another example, Summerh111, it becomes apparent that the upper and middle class white free school would tend to operate more in a pseudo-political vacuum whereas the obvious intent of the free school of Jonathan Kozol tends toward a recognition of the polftical real1ty. 128

Kozol chose to exclude the white upperclass schools from his discussions, saying their problems was of a very different nature "... which transplres at all times within the safe and nonpolitical context of the white, the whimsical, the privileges the not-1n-need...."129

126Jonathan Kozol, Free Schools, Bantam Books (1st Rev. Ed; New York: by arrangement with Houghton Mifflin Company, Boston, 1972), pp. 16-17.

127 Ibid., p. 53.

${ }^{128} \mathrm{~A}$ prominant example of this political reality can be seen in Edgar Litt's study of the civics curriculum in Boston. He concluded the type of polftical role that students are "trained to play vary according to the social class of the students." See Edgar Litt, "Civic Education, Community Norms, and Political Indoctrination." The Learning of Political Behavior. Edited by Norman Adler and Charles Harrington. (Glennview, Illino1s: Scott, Foresman and Company, 1970).

${ }^{129}$ Kozol, Free Schools, p. 43. 
In actuality, even as Kozol admitted, neither is non-political, but the alms and needs must be approached in a different context. And for this reason he defended the movement for free schools of the nature of his own definition.

An example of a free school is one started in Ann Arbor, Michigan In 1966 which failed when Black parents withdrew their children from 1t. The reasons were many but the final assessment was that the students did not learn to read. Closure was based on harassment from local officials but the overriding factor was a loss of pupils and loss of support from parents. 130

In defending "his" varlety of "free school" Kozol expressed his support for the fundamentals and his disdain for those who say ...that their children do not need competitive skills do not need math, do not need English, do not need to find out how to psych out a complex and difficult exam, do not need universities, do not need money, do not need ugly, wicked, contaminated middle-class success. 131

Another example of educational innovation 1s the type of school that Kozol does not speak of, the large public school such as John Adams High School in Portland, Oregon or the Parkway Project in Philadelphia. While such experimental programs have had various successes under the umbrella of a university program for teaching or curriculum Innovation in the past, 132 few large scale public programs have been undertaken. Robert B. Schwartz, Adams principal and a

130Kozo1, Free Schoo1s, p. 37.

${ }^{131}$ Ib1d., p. 49.

132 IIncoln School with Teachers College Columbia University, Cook County Normal Schools "practice school" are examples. 
member of the team who created Adams, cited this distinction:

...the history of University based laboratory schools was that they had had little or no influence on the public schools largely because they served an elite student population and were not subject to the same politics and financlal pressures as public schools.133

Located in a geographical area which consisted of primarily lower soctoeconomic population, Adams sought to offer an open general curriculum "...to provide students with a base of knowledge and a set of communication skills that w111 be useful...."134

The curriculum was designed with freedom a foremost element, freedom for inquiry without the constraints found in a traditional high school. Less than half of the day was scheduled and the mandatory attendance of the traditional school was abandoned. Upon opening, a parents group called Citizens for a Better Adams, was formed. An early review of the program in the PhI Delta Kappan demonstrated the parental concern:

Adams High School does not teach respect for authorlty, discipline, basic scholarship, or orderly use of time. The school teaches gross egotism, extreme self-çenteredness, myoplc self-delusion, and general anarchy. 135

133 Robert B. Schwartz, "Profile of a High School: An Introduction," Phi Delta Kappan, III (May, 1971), 515.

134 Allen L. Dobbin, "Instruction at Adams," Phi Delta Kappan, LII (May, 1971), 516.

135"The John Adams Team", PhI Delta Kappan, LII (May, 1971), 514. 
Their concern had some basis as later changes were made to modify the program by addition of a more traditional core curriculum for those students In need of a more "conventional" education. Race and rowdiness caused extreme disturbances for the first year in operation and surveys taken of the school population revealed many complaints about the poor learning environment and lack of structure, Other changes were made to adapt the school to overcome these criticisms. Some reports were interjected Indicating a complete disbanding of the nature of the school but the Superintendent of Portland Public Schools himself stated "no administrative action has been taken to change the central and Important thrust of this important program."136

Problems 1dentifled with the program and c1ted by its innovators are a) difficulty in producing research and evaluation in terms of cost, techniques and time, b) burden on teachers in terms of time with respect to a traditional curriculum, and c) miscellaneous difficulties adapting a curriculum to this selected socio-economic population. Superintendent Blanchard, at the end of its first two years of operation stated

'Adams is probably dolng no better nor worse in achlevement than any Portland High School with a student body socto-economically comparable. 137

\footnotetext{
${ }^{136}$ Donald W. Robinson, "Are They Quietly K1lling John Adams," editorial, Phi Delta Kappan, LIII (October, 1971), 81.

137 Ibid., p. 81.
} 
But Adams has been modified ${ }^{138}$ in certain respects to revive certain conventional elements to assure that its students leave with the skills intended by the existence of a high school and it continues to operate within that context.

Another alternative threatening the traditional public school is the recent surge of private schools; not necessarily those of an elitist or military nature but church sponsored schools. While Roman Catholic parochial schools have always been the preponderant religious alternatlve school, recent trends have seen Protestant school numbers increasing by 66 percent since 1965. At the same time Roman Catholic schools, in financtal trouble, have closed down 2, 778 schools in the same period. 139

Busing and the race issue may account for much of the increase but it is alleged that the parents are seeking "...a learning environment for their youngsters that is more disciplined and more religious than can be found in any public school.140

Other commentary from a representative of American Association of Christian schools called the public schools "...like charity hospitals -- you go there when you can't go anywhere else" and described the new private schools as "...mostly fundamentalist or evangelical institutions, with a traditionalist approach to

${ }^{138}$ Greater attendance requirements, as one example. 139 "Boom in Protestant Schools," U.S. News and World Report, LXXV (October 8, 1973), pp. 44-46.

${ }^{140}$ Ibid., p. 44 . 
education."141

The alternatives to traditional public education in the United States are too numerous to explore in this paper. Some are fundamental structural changes in curriculum and others are merely small changes which are easily implemented. One on-going controversy that can be analyzed in the context of educational alternatives is the voucher plan. Advocated by many as a means of providing educational alternatives to our young, it is suggested that it could provide this for some, the more well-to-do, but that it would lock the poor into the public school. It is suggested that 1 t would violate separatism of church and state requirements and that it would promote segregation. The question of how the retarded and the lower-socio-economic groups would fare is a widely debated topic, one which can only be answered by the form or structure of the voucher program.

Middle schools, year-round schools, open classrooms, educational parks, black studies, accountability, paraprofessional and nongraded classrooms are fust a few of the many other innovations which are being explored in the $60^{\prime} s$ and $70^{\prime} s$ just as the kindergarten, the funior high school and the platoon system were being explored at the turn of the century. From the history of alternatives to the traditional forms of education, it appears certain that the fate of many of the new alternatives will be dealt with within the political arena, one way or another.

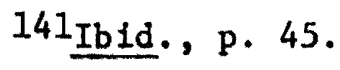




\section{ENDURING THEMES IN AMERICAN EDUCATION}

From the cases previously discussed, regardless of time or setting, three themes were constantly observed.

1. The destre of the people to have all children successfully master the basic fundamentals of reading, writing and arithmetic,

2. The desire of the people to have the schools emphasize moral and spiritual values which were similar to their own, 1 and

3. The opposition of the people to what was believed by them to be an attempt by the school to foster some dimly defined kind of socialistic theory which would replace individualism with group goals and competition with cooperation.

This chapter first analyzes the previously described cases and situations in terms of these three themes. Following this analysis,

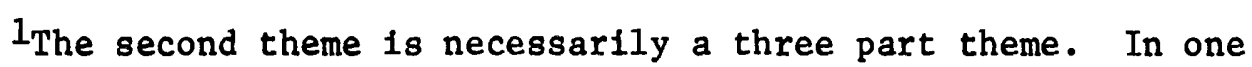
case values might be reinforced which are unacceptable to parents, in another, values held by the people (or parents) might not be taught at all, or values held to be acceptable by the parents are taught by the school. The first two varlations are held to be the essential nature of this theme. 
a general model of "the school as a responsive political system" is constructed in order to display the operative nature of the three themes in schematic form. And finally, in order to demonstrate the timeless quality of the model as constructed and its adequacy, a brief general discussion is undertaken. 2

As evidenced by the varying complexities of the previously discussed cases, any attempt to develop an elaborate all-encompassing political system for public education would be an Immense undertaking. If one was to attempt such a project he would have to be concerned with all of the aspects of the environment that the system exists in as well as the general extensive classification and categorization of Interest groups. In addition, he would have to concern himself with the quality of policy and product output. Moreover, one would have to be concerned with the intricate interplay among all involved actors, administration and policy making types as well as supporters and challengers. Yet any one of these areas would provide fertile grounds for an in-depth study in the politics of education. St111 another approach would be to take Easton's theory as described in Chapter I and relate it to each individual case or controversy. Such approaches, however, do not lend themselves best to the ends sought by this thes1s: the Identification of general themes that have generated controversy in public education.

${ }^{2}$ of necessity, this will rely on the cases as described in this thesis and will stress the more general themes rather than speciflc local issues. 
And whereas the development of an in-depth political system for public education in the United States would be a Gargantuan project, a simple framework such as that provided by Easton's model provides sufficient framework from which to view the nature of the themes in terms of a polftical system. With the identification of these themes, one can then discuss the various aspects of a general, simpliffed mode1. This enables one to ascertain the role of the themes in such a system.

Analysis

The decline of educational opportunity for the Negro in Alabama Just after the Civil War unt 111901 can be attributed to a complex series of events. In one respect the legislature and the courts were prime actors. In addition, the emergence of industrialism and the transformation of agricultural trends created a setting for these prime actors to operate $\ln .^{3}$ And finally, it involved the aspect of moral and spiritual values and a quest for sound basic education.

It becomes obvious that what the white Alabaman sought for his children was increased educational opportunity, even if it was at the expense of Negro education. The educational system of Reconstruction favored the Negro in the sense that his tax investment was low compared to his educational opportunity whereas the more prosperous, landowning white families carried a heavier tax burden for education. As

\footnotetext{
3 Bond, Alabama.
} 
Industrialism accelerated and urbanism began to transform parts of the landscape, greater demands were made to provide more funds for white schools, either by officially segregating school financing, going to a local tax support system ${ }^{4}$ or by taxing each race for their respective schools. Efforts to remedy the Negro tax situation finally proved successful in the constitutional convention of 1901 in a formal sense. The Immediate result was a new distribution of tax revenues for Negro and white education. The apparent desired result was an increase in the quality of basic education for the white Alabaman. And even if the legislative action appears to have been a compromise between the Black Belt and the urbantzing-industrializing areas, ${ }^{5}$ the alm of both appear to have been to increase funding for basic education for white children whether by reallocating from Negro education or by merely Increasing state school support.

In the sense of moral and spiritual values one would conclude that it was not merely the whites who preferred separate education. Racism did accelerate after the C1vil War and the white Alabaman's ractal hatred was spurred by an increasingly competitive industrial society. But it was the Negroes in the Constitutional Convention of 1867 who testifled that they did not want to send their children to

\footnotetext{
${ }^{4}$ It had been primarily a state-collected and distributed fund prevlously. For a discussion of the issue, state-collected versus local taxation, see: Horace Mann Bond, Negro Education in Alabama (Washington D.C.: Associated Publishers, Inc., 1939). pp. 132-34, pp. 183-88.

$$
5 \text { Bond, Alabama, p. } 157 .
$$
}


school with whites but that they did want to insure that inferior Negro schools were not maintained. ${ }^{6}$ But the white's increasing attacks on the Negro gave testimony to the white Alabaman's reluctance to have his children educated with Negro children. 7 The parents of the children in Alabama sought a school environment which reflected their basic value structure, morally and spiritually.

In a sense then, two factors appear primarily responsible for the decline of Negro education in Alabama. One, the white Alabaman sought superior education for his children (over and above any Negro children). And secondly, he sought a propagation of his values and mores through the schools. There were other issues but the 1ssue of racism provided the vehicle through which the chasm between white and Negro education in Alabama became ever widening.

The controversy over the institution of trade school education in the public school was an issue that ralsed questions over the content of public education on one hand and of spiritual values on the other. The 1dea of offering such a course of study in the public schools generated controversy. One criticlsm called the content subversive to the "proper and primary work of public education." 8 Presumably this

6 Bond, Alabama, p. 93.

7Bond, Alabama, p. 172. A statement by an Alabama leglslator went as follows: "He thought that there was no Negro as good as 'the least, poorest, lowest-down white man he ever knew."'.

8National Education Association. Addresses and Proceedings (Washington, D.C., 1880), p. 225. Emerson White's criticism of the movement as capsulized by Lawrence A. Cremin, The Transformation of the School, Vintage Books (New York: Alfred A. Knopf, Inc. and Random House, Inc., 1961), p. 29. 
proper and primary orientation was that of the formalistic, authoritarian educational schema through which children learned the basics of reading, writing and arithmetic, a form which also was held to be within certain bounds of which one could call common. In the view of many of the critics of trade school education in the public schools, the essence of American public education was the common school and to infect a variety of craft and skill training into the curriculum detracted from that essential nature of public education. In this sense the promotion of the common school, void of skill training, 11lustrated a certain equalitarian theme, a theme which promoted a comon culture through basic formal education.

Other opponents of trade school education claimed that it did not distinquish between higher and lower faculties, the higher aspects presumably being the traditional formal education and the lower, a common form of skill training. By this one might conclude that opponents of the trend opposed it for the reason that they held that form of training in low esteem. Likewise, proponents sought to dignify labor and the trades, and sought to promote trade school education.

Evidence that rural agricultural education underwent simflar underlying conflicts is apparent, but in the case of the former the conflict was in the nature of survival of a way of life. The rural youngster was growing up, becoming educated and then fleeing to the new urban areas to fobs, security and other comforts. To preserve the status of the agricultural way of life the farmer wanted his children educated, not only in basics but in moral and spiritual values similar 
to his own. In a sense the farmer realized that the young needed the basic education to cope with the increasing complexity of agrarian Iife, but at the same time values such as those promoted through the "agrartan myth" were needed to preserve the faith of the young in the rural, agricultural lifestyle.

Both conflicts, one involving trade school education and the other Involving agricultural education were far different in content but both maintained simflar themes. Both contexts promoted basic education in reading, writing and arithmetic; and both issues were developed over a question of values. Whereas the proponents of the trade school education did so to dignify labor or skill learning, the farmer promoted agricultural education to dignify the farm lifestyle and the values that it held.

The emergence of American schools from a rigid authoritarian form of education to a new form with new approaches and techniques created praise within some circles and bitter criticism from others. All three aspects which are being analyzed in this paper are in evidence in this discussion of progressive education. Charges of students not learning the fundamentals is present in many of the cases, the issue of moral and spiritual values assumes various forms but yet is present, and the lssue of Individualism versus collectivism assumes a low-key but constant profile in any discussion of progressive education.

9 For a discussion of this so-called myth, see Richard Hofstadter, The Age of Reform. Vintage Books (New York: Alfred A. Knopf, Inc. and Random House, Inc., 1955), pp. 23-59. 
One of the earliest pioneers of child-centered education, Horace Mann, drew sharp criticlsm from local educators and parents in Massachusetts when he suggested a more liberal child-centered approach to the schools. ${ }^{10}$ Since church-sponsored schools were predominant before public education became the common form, and since those who patronized the public form were usually of a lower socio-economic class, to want to use that school as a means of control and discipline to the values of those who promoted the schools is possible. ${ }^{11}$ In another sense the authoritarian form was not uncommon in private or religious schools though, which suggests that this was a value held by many people, a value which one would hope to have the schools promote to the1r children.

The discussion of Colonel Parker's "Quincy System" provides an example of an instance where the new liberalization of educational form was undertaken with resultant improvement in fundamental subjects. The implementation of the system, whoever, drew criticism. ${ }^{12}$ A great many in the community questioned this new and different approach because of its liberal, child-centered approach. But the facts prevailed, there

${ }^{10}$ Charles E. Silberman, Crisis in the Classroom, Vintage Books (New York: Random House, 1970), p. 59

${ }^{11}$ Ibid., p. 60 .

${ }^{12}$ Lawrence A. Cremin, The Transformation of the School, Vintage Books (New York: Alfred Knopf, Inc. and Random House, Inc., 1961), pp. 128-31. 
was improvement in the children's abilities in the basic subjects of reading, arithmetic, spelling and writing. At a later date, when in Chicago at Cook County Normal School, local authorities criticized Colonel Parker's approach suggesting the children weren't learning. The apparent concern was the work habits which would relate to moral and spirituai values, and also achievement which would relate to the learning of the fundamental, formal subjects. The controversy is sald to have continued for some time, but no specific changes in the curriculum were suggested.

The development of the "Gary System" provides a case in which new progressive innovations were found to produce learning levels in the basic subjects of mathematics and speling which were below the levels found in the traditional public school. 13 It was presumed that the child in the new liberal learning environment was certain to improve his learning abilities not only in skill related areas but also in the more formal areas of arithmetic, spelling, and reading. SkI1I training was provided, a fact that might be accounted for by the Industrial nature of Gary. Accepted by and large in Gary, the new system was a proud accomplishment for its new citizens. However, later in New York, when the Gary Plan was being discussed for possible installation there, the issues of achievement and learning came to the forefront. Although it was a political campaign that claimed the system could not live up to Its claims, a study was undertaken to prove or

\footnotetext{
${ }^{13}$ IbId., pp. $154-60$.
} 
disprove the charges. The conclusion was that the children performed sub-standard in spelling and arithmetic and other formal areas of study. 14

other criticism of the plan was based around the fact that United States Steel Corporation (U.S. Steel) was assoclated with the plan. Accepted in Gary, the plan produced skill oriented "products" whereas in other cities the stigma of "big business" controlifng or influencing education or educational policy found disfavor. Such was the case in New York, Chicago and other cities. The values that these critics promoted might be classifled as pro-labor or at least ant big-business. The might of big business of the era frightened these people and as a result they tended away from public policy or school policy that would favor big business.

While the various public plans such as the Gary Plan and the Quincy System were being implemented, a host of private experimental schools were being developed. What is significant is that the private school must be viewed as being more independent from varlous polftical agencies than its public counterpart. For this reason and the fact that attendance at such schools was strictly optional, various conclusions regarding the parents' motivation is in order.

John and Alfce Dewey created one of the first truly experimental schools in 1896. "Laboratory School" was used as a model for many to come after it had closed its doors. Those who sought this new brand of education sought sound learning for their children, but in a child-

${ }^{14}$ Ibid., p. 159. 
centered fashion, a form which attempted to promote creativity and excellence in learning through new methods. It is apparent that a common element was present in those who patronized the schools. They wanted their children to be free of the burdens of testing and grades and any other traditional facets of public and private education that would retard interest and learning. By removing these barriers their children would presumably be spurred on to greater learning through individual initiative. The critics, however, charged that with no means of evaluation, no gauge of progress or learning was possible. The results of various testing programs did support the fact that in some cases, learning (formal) was inferior or at best only marginally superior. ${ }^{15}$ There are of course exceptions but the tendency suggests that the criticism was valid.

An exception to the rule can be seen in the Lincoln School. Performance on all testing programs was high. But it is here that one has to recognize the ability level of those attending. It is suggested that those attending genuine experimental progressive schools can be virtually placed into an upper-middle class grouping. This in itself suggests two significant points. The parents of the students sought not only a sound, quality, creative education but also an atmosphere which reflected their basic norms and values.

${ }^{15}$ Flexner's and Backman's study of Gary for example. See Lawrence A. Cremin, The Transformation of the School. Vintage Books (New York: Alfred Knopf, Inc. and Random Hoụse, Inc., 1961), p. 159. 
The third aspect which prevailed over the general movement can be seen in the writings of John Dewey and the resultant criticism. At first Dewey was a prominent supporter of progressive education, and later, he wouldn't even join the Progressive Education Association (PEA). Elements of the movement were adopted across the United States in the public schools with few adopting an entire program. The movement, however, gradually vanished. Money became scarce for spectal programs, public schools had adopted aspects of progressivism and child-centeredness, learning was never shown to be superior by any substantial proof, and the controversy of altering the attitudes and 1deals of the children In directions contrary to what were commonly held to be American ideals proved to be the downfall of the movement. The last item was the type of issue that continued to plague the movement since the publication of some of John Dewey's early essays. However, recognizing that the issue was one of the relationship of the individual to society and vice-versa, this paper will not attempt to develop this other than to say that it was feared that the methods of progressivism and pragmatism would lead to a lack of individualism and be replaced by a collective spirit, a spirit that relied on vast cooperation between students and ultimately adults. Seen as elements of a far-flung conspiracy, progressive educators were frequent targets for criticism of this nature.

In overview, the patrons of progressive education did seek quality education for their children but likely one which reflected their own moral and spiritual values. From the cases examined in this paper one would have to conclude that experimental schools falled for various reasons: only moderately good levels of achievement were 
maintained; the lack of evaluative methods did not allow parents to see concrete progress in their children; many public schools incorporated elements of the progressive approach into their curriculums; and the movement was beset with susplcions from parents and politicians about the purposes served and the ideals promoted. The "Americanization $^{16}$ ethic which fluctuated from time to time during this period and since, can doubtless account for much of the controversy with regard to individualism and collectivism.

While experimentalism occupled the vanguard of educational Innovation during the early $1900^{\prime}$, many existing public schools attempted to incorporate the new "progressive" and modernizing aspects to their curriculums. At the same time, as in the case of Chicago, the local political environment caused marked reaction to the suggested changes. 17 It was in Chicago during the tenure of Mr. William McAndrew that one can find evidence to suggest that the complex educational political controversy did indeed involve all three of the aspects suggested, and in such a manner over a period of time to force the removal of Superintendent McAndrew. No one 1ssue in itself can be

${ }^{16}$ The writer recognizes that the term Americanization could have countless interpretations. However, it is used here in general terms to mean the thought which promotes proper American behavior. Viewed in terms of masses of immigrants 1 t would connote a process of inculcation of values, language, and other aspects which agreed with native feelings and attitudes. It looks to general conceptions and perceptions of the public at-large. In a similar but different instance, the post-World War II period brought out strong feelings of Americanism. Both instances looked to the public attitudes as to what proper American behavior was.

${ }^{17}$ George S. Counts, School and Society in Chicago (New York: Harcourt, Brace and Company, 1928). 
Identified as being responsible for the course of events in Chicago and some other activitles which helped to deteriorate the strength of the superintendent did not fall within the three themes being discussed. But the primary issues involving public support of the superintendent via-a-vis the election of a known machine politician of suspect motivation appear to be expressed in part through the issues that made up the successful candidates' campaign.

Prior to the mayoral election the new superintendent attempted to modernize the Chicago school system. His attempts to install the platoon system found disfavor among the teachers in Chicago. The teachers maintained that the platoon system was educationally unsound, whereas local women's groups supported it. Support was the same for junior high schools but with no clearcut position from teachers. Labor resisted both while the Chicago Tribune supported them. ${ }^{18}$ Both 1ssues tend to possess elements of the aspect of sound basic education as well as the desire of the people to have the schools emphasize moral and spiritual values similar to their own. The educational soundness of the platoon system was questioned, and judging from the New York study of the Gary System, rightfully so. Chicago, with a large labor force viewed the platoon system as a big business infringement on labor. The concreteness of these allegations are elusive, but the mere association of the innovation with big-business seemed enough to produce alarm in those who represented labor that big business would not only try to

${ }^{18}$ Ibid., p. 58. 
economize on the soundness of the basic education but also potentially attempt to inst11l values contrary to what the largely labor population would desire. Another innovation of the period, intelligence testing, raised the suspicions of labor that big business was trying to introduce a "caste organization society"19 into Chicago. Those of the lower caste would no doubt be labor. For this reason the attempt to introduce the junior high school falled. It represented to some, an apparent attempt by the new superintendent and others to remove an element of the common school by further fragmenting it. ${ }^{20}$ This threatened a value, strongly held by the old and new stock in America. It was a threat to the equalitarian, common school.

When William Hale Thompson ran for mayor his primary issue was educational policy and the schools in Chicago and he declared that he would oust the superintendent if he was elected. Ex-mayor Thompson's campalgn was a dramatic affair with a constant barrage of criticism of the previous mayor and the school superintendent. His main allegation was that the school superintendent advocated un-American teachings. The incumbent, Mayor Dever ran a low-key campaign merely stating and restating the accomplishments of his term, primarily in the area of education. 21 One would have to say that earlier charges of teaching pacifism against the superintendent might well have suggested to the

$$
\begin{aligned}
& { }^{19} \text { Ibid. , p. } 333 . \\
& { }^{20} \text { Ibid., pp. } 170-77 \\
& { }^{21_{\text {Ibid. }}, \text { p. } 272 .}
\end{aligned}
$$


public that his orientation was aligned with other local progressive educators and experimentors. 22 And in all likelihood, it was suggestive of his orientation toward group goals and cooperation versus individualism and competition. Then the charge of un-American teachings would naturally tend to reinforce earlier suspicions, whether they were valid or not. In this manner, un-Amertcan teaching was contrary to what the striving labor pupulation saw as proper, "American" behavior. And proper "American" behavior was in a normative fashion in that period, the Americantzation ethic, which each individual placed in high esteem in terms of moral and spiritual values. 23 Other aspects of the controversy were teachers' councils, city hall politics, and staff organization in the schools. These, however, seem secondary to the 1ssues discussed herein. Thompson was re-elected, a fact that requires careful treatment since it was acknowledged that he was a central figure in graft and corruption in city government. That he was re-elected by a strong plurality is evidence in itself that a majority of the people supported him as a person, or his platform with all of its allegations. The former is unlikely as they voted him out previously for corruption. The latter, if true, indicates that the issues of education in terms of educational basics,

22 And of his relationship to prominent educators at the liberal University of ChIcago.

${ }^{23}$ The quest of allens to be assimilated and native pressures in the press, schools, military service and myrlad organlzations to promote this Americanization, loosely defined as pressure to glorify everything that was American; history, language, progress, etc. 
moral and spiritual values, and charges of a sort of un-American, pacifistic, collective, liberalism accounted for Thompson's re-election.

The aftermath of the McAndrew controversy was a course of events that proved damaging to the normal operation of the Chicago school system. As the depression economy reduced tax revenues, the school system floundered with its inability to pay teachers. ${ }^{24}$ The same type of situation prevailed in depression Atlanta. ${ }^{25}$ There, attacks on night schools, Negro schools, kindergartens, music, art and teachers' salaries can immediately be seen as attacks on the high cost of education. To suggest that it was the only basis for conflict, though, underestimates the scope of the issue. If one presumes that the public school by this perfod was generally an accepted and widely supported institution and that the attacks on the areas mentioned seemed to single out areas subsidiary to the "basics," then one might also conclude that the criticism was directed at the frills in the schools, which were secondary to the primary purpose of the public schools, teaching the basics. $^{26}$ In another sense these adjuncts to the basics may well have represented values in a moral and spiritual sense which were allen to the basic value system of those who promoted the attacks.

24"The Plight - of the Chicago Schools," editorial, School and Soclety, XXXVII (May, 1933), p. 578.

${ }^{25}$ A History of Freedom of Teaching in American Schools, Report of the Commission on the Soclal Studies American Historical Association, Part XVI, Howard K. Beale, Chairman (New York: Charles Scribner's Sons, 1941), p. 265.

26 The basics being the more formal and traditional areas of study in the schools; reading, writing and arithmetic. 
The Inclusion of Negro schools and real estate owners as elements of the case give support to this possibility. One might say these attacks were indeed twofold, an aspect of basics and reducing frills and an aspect predicated upon moral and spiritual values, with the actual attacks appearing in the form of an economy drive.

A few years later the serles of attacks in the public schools across the nation maintained elements of each of the aspects developed In this thesis. But, whereas earlier attacks on the learning of fundamentals came in various subtle forms, the latter attacks were more blatant in nature. Coupled with this, a revival of conservatism, as the "red" Ideology generated fears of an impending, liberal conspiracy, swept the country. Combined, the issues provided a focal point from which to take aim at moral and spiritual values that were "distinctly un-American." As such, controversies in school systems in Denver, Colorado; ${ }^{27}$ Port Washington, New York; ${ }^{28}$ Eugene, Oregon 29 and Pasadena,

27Lawrence Martin, "Denver, Colorado," The Saturday Review of Literature, September 8, 1951, pp. 9-10, as reprinted in C. WinfieId Scott and Clyde M. Hill, ed., Public Education Under Criticism New York: Prentice-Hall, Inc., 1954), pp. 303-309.

${ }^{28}$ Louis Enge1, "Port Washington, New York," The Saturday Review

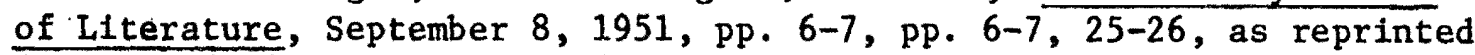
in C. Winfield Scott and Clyde M. Hill, ed., Public Education Under Criticism (New York: Prentice-Ha11, Inc., 1954), p. 307.

${ }^{29}$ W. M. Togman, "Eugene, Oregon," The Saturday Review of Literature, September 8, 1951, pp. 10-12, as reprinted in C. Winfield Scott and Clyde M. Hill, ed., Public Education Under Crit1cism (New York: Prentice-Ha11, Inc., 1954), p. 316. 
California ${ }^{30}$ revolved around the teaching of the basics, moral and spiritual values and a fear of a liberal school orlentation which was un-American in nature and against the "ethic of the individual." 31 of the four cases mentioned, the first three had distinct similarities in general. Each made specific attacks on the schools for neglecting "fundamental learning," and not teaching sound education in reading, writing, and arithmetic. The Eugene case further elaborated on the 1ssue of basics. Not only did the angered Eugene citizens want the "three R's," history, literature and solid content sciences, they wanted more discipline within the school, more rigid grading scales and fewer teaching aids. The request for a decline in the use of audio-visual alds and other "entertainment" devices was understandably similar to charges in Port Washington of extravagant use of these types of aids. The action sought by those who attacked the schools was a change to a more basic, fundamental education, a change which in the case of Eugene, Oregon was demanded In a form which would accent discipline within the school, a value likely held in high esteem by the parents.

Th1s demand for a return to basics would appear to be an effort to challenge alleged 1iberal, progressive educational systems. Charges

30 The Pasadena Story, National Commission for the Defense of Democracy Through Education, John W. Davies, Chalrman (Washington, D.C., National Education Association, 1951). Also see David Holburd, This Happened in Pasadena (New York: Macmillan Company, 1951).

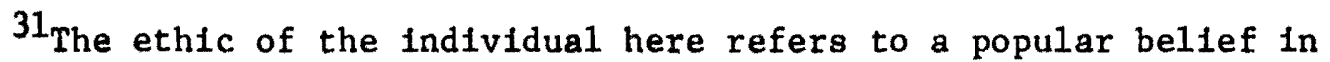
the primacy of the Individual in American soclety with unlimited growth potentials, etc. 
of a Red conspiracy of sorts within the school systems was also a common element, an element that was twofold. In one respect, it held values that were intrinsic to the parents' upbringing. One, a proAmerican philosophy that honored ingenuity, opportunity and individualism was a deep-seated value across the United States. Secondly, the United States' excursions abroad and increasing international immersion in the affalrs of the world renewed fears of soclalism, communism and any philosophy that would imply a replacement of individualism with group orientation. By various interpretations of the day, it was suggested that the progressive philosophies of earlier years intended to subt1y overcome the "true" American ethic of individualism and competition. As such, the threat to tradition created animosity and fear in various citizens which manifested itself in attacks on the public schools, one of the most visible agents of socialization.

The Pasadena case Involved all of the aspects mentioned in the previous cases and more. Superintendent Goslin was from all appearances an active, progressive educator who desired to upgrade the school program, develop an interested and qualified teaching staff and upgrade facilities to allow for a superior program. But it was these very elements of the man and the stuation that the conservative citizens of Pasadena took 1ssue with.

To Improve the school program and upgrade facilities in the inflationary post-war era, additional tax levies were needed. The first building bond 1ssue handily passed. The second falled. In the first bond election, the issue was simple, money was needed for new factlities but the second one was more complex. The money was sought to 
shore up the educational program which inflation had devalued. At the same time, the issue of where to put the facilities that the first bond 1ssue had approved was opened. The upper middle-class who had previously been spared schools common to the lower socto-economic groups balked at the superintendent's progressive, equalitarian ideas. The real estate lobby and home owners associations became active. These parents wanted a good education for their sons and daughters, but one which reflected their own moral and spiritual values, values which were common to their own socio-economic status.

Comments that he was attempting to subvert the youth of Pasadena were common. His remarks about Federal Aid to education and his relationshtp to W. H. Kilpatrick of Teachers College, Columbia University were interpreted as subversive. ${ }^{32}$ His personality, from all appearances, did not generate much support from the local press or from within the school district administration. This may have accounted for the passive role of the local press. But the larger 1ssue involved charges of un-Americanism and attempts to subvert the youth of Pasadena. To the conservative citizens of Pasadena, his attempts to force his equalitarian themes on the children threatened those citizens. Their freedom of cholce in school was being challenged and they were being asked to pay more money for tt at the same time. Through this and the association of progressive education with a collectivist group

32 James B. Conant, "The Superintendent was the Target," in Public Education Under Criticism, ed. by C. Winfield Scott and clude $M$. H111 (New York: Prentice-Ha11, Inc., 1954), p. 101. 
goal orlented philosophy as a replacement for Individualism, certain citizens of Pasadena balked and crled un-Americanism. 33

This case then, as do the previous three, possesses a complex entanglement of the three aspects discussed. It was alleged that the fundamentals were ignored because progressive education concentrated on frills and that progressive education was un-American because the group goal rather than individual, and cooperation rather than competition was taught. It is apparent that the critics of each of the school systems viewed the aspects as threats to the American way, or at least the values they percelved as representing Americanism, Individualism and competition. It is also apparent that they felt to preserve that which they percelved as American, the youth would have to recelve a traditional fundamental education.

As one views these controversies it becomes clear that the Intent of those who challenged the school systems was generally to seek sound, superior education for their children. It is also apparent that the values, efther spiritually or morally, were those elther held or promoted by the parents and that often the aspect of Individualism versus group goals and competition versus cooperation (which hinted at a socialism of various definition) were a part of the controversy. And while these aspects have a tendency to appear in various 1ssues, in some cases one, two or three aspects being involved In a given issue, one is able to conclude that the aspects do have a timeless quality in that they are applicable to virtually any

${ }^{33}$ NEA, The Pasadena Story, p. 15. 
controversy in education, be it 1900 or 1955 . The issues which provide the conflict though are of course the issues of the day. Whether one looks at the religious educational conflict of the $1800^{\prime}$ 's or education during the Great Depression, the charges of indoctrination of the Joseph McCarthy period in the early 1950's or the conflict in white and black education after Brown-versus-Board of Education, or even the trends to educational alternatives of the 1960 's, each controversy maintained issues pertinent to each period, yet as can be observed, each controversy can be ultimately reduced to a matter of educational basics, or moral and spiritual values, or allegations of subversion of sorts, or any combination of these three aspects. This quality can better be observed with regard to trends and issues in the following analyses.

In the early 1800's the public school, or common school as 1 t was to be known, galned increasing support from the public. Churches which previously had performed in the role of educator, both morally and spiritually, gradually yielded to the common form of education for al1, the public school. But in ylelding the responsibility for this Important area of upbringing, controversy was inevitable. The case of New York $\mathrm{City}^{34}$ showed denominational alignments that matured to a position which accepted public schools, schools where no religious sectarlan doctrine was to be taught. The ideals and values promoted

34Elwood P. Cubberly, Public Education in the United State, (Rev. and en1. ed.; New York: Houghton-Mifflin Company, 1934), p. 236-37. 
by the denominations were in themselves alien and suspect to each other, but guarantees of removing them from the scope of education appears as though it was primary to their acceptance of the public school. Massachusetts developed a similar controversy, 35 but in that case, the lack of relfgious training proved to be the source of criticism. Charges of "Godless schools" showed the concern over the schools avoiding the customary religious orientation of the school. The church, after all, had been a vital and important center of social relationships, communication and community. To withdraw its influence from an area of traditional importance was certain to develop concern in its patrons. In the case of New York, with all of the conflicting religlous groups vying for a role in public education, the cholce for popular acceptance among the groups was the elimination of the teaching of religious philosophy, and to attempt to remove the teaching of moral and spiritual values, uncommon to the public at large, from the schools. In the case of Massachusetts, with a strongly fundamentalist school board, criticism for removing the teaching of moral and spiritual values from the school was obviously based on the values held by the critics. Public education in their view removed the teaching of certain values from the schools, values which they felt should be taught in the schools.

The question of values became even more a subject of controversy after the Civil War as industrialization and vast Immigrations to the

$$
{ }^{35} \text { Ib1d. , pp. 233-35. }
$$


United States swelled the population and created large urban areas. John Higham made this evident in his discussion of American nativism, 36 the challenge to the native Protestant stock by the immigration of large numbers of persons with alien customs, a large number of whom were Catholic. The expansion of parochial schools threatened the traditional attitudes and ideas of native America. In order to assimilate the immigrants, they had to be taught the customs of the new land, the new language and behavior viewed as proper by the old stock. Public education provided this vehicle. Denominational schools were discouraged because less funding was available for them from local and state agencles while the quest for a common culture, 37 promoted non-sectarlan schools.

Development of a form of education in which large masses of people could be educated to fill various roles in the evolving Industrial society was not without growing pains. The muckrakers of the reform period showed time after time how the area of education had become an area of patronage. The McAndrew case gave a prime example of this. The, controversy of trade school education in the realm of public education provided an on-going debate on the inherent value of that form of education to the Individual. However, the need of the evolving industrial order proved to be the final determinant. By the end of the debate, that aspect had been transformed into an

36 John Higham, Strangers in the Land, Atheneum (New York: by arrangement with Rutgers University Press, 1963).

37 oriented of course to native Protestant values and customs. 
acceptable adjunct to the basic education that the public schools were to provide. Progressive education and its trust in child-centered education in a variety of forms came and went. The economy grew and with it the extent and diversity of education. Yet the basic philosophical overtones in the field of education were conservative In nature, almost a populistic conservatism in which the primacy of the individual was held in high esteem. At the same time a progressive tenor abided which viewed the past eras as those of the so-called "good-old-days" of true political democracy and individualism. But the concerns of the 1920 's were mild compared to the shock of the Great Depression.

Where a growing vigorous economy once supported myriad corporations with escalating profits, the failure of the economy caused great concern among social critics and educators. Author, writer, educator George Counts took the social order to task. ${ }^{38}$ He claimed that education was not responsive to the needs of society and that the society had transformed from an agrarian culture to an increasingly industrial1zed urban order in which the great masses of people should be considered as primary. He proposed that a redefinition of progressive education be undertaken, and without fear of the use of indoctrination or imposition. Through this he viewed education as a means to question the politics, morals and religion of the existing social order. But such an approach ran counter to previous conceptions of

${ }^{38}$ George S. Counts, Dare the School Build a New Social Order? (New York: John Day Company, 1932). 
public education. The public school was considered to be a form of acculturation in one sense as a means to educate children in the basics to enable them to fit and grow in the expanding industrial soclety. As one can see though, the 1deals of Americanism as evidenced In the McAndrew case, and the debate over progressive education and the primacy of the individual display the values that were common to the perlod. What Counts asked for was not unlike many of the actual actions taken by the federal government during the depression, but to suggest that public education depart from a supposed neutral, nonIndoctrinating, non-imposing form was viewed as a radical departure from everything that was American. In a third sense it suggested a socialistic connotation to many critics. The label of radical that the critics pinned on Counts and finally on the PEA ultimately contributed to the demise of that organization, ${ }^{39}$ testimony in 1tself of the Importance of conflicts regarding individualism and competition over group goals and cooperation in American education.

Accompanying earlier critlclsms of education in the school systems of Pasadena; Port Washington, New York; Denver and Eugene, Oregon were wholesale condemnations of varfous textbooks in use around the country. Various publications made attack after attack on the so-called 1iberal slanted textbooks of American history, American economics and other flelds. The changes claimed that the American children did not understand American 1deals, American politics, American economics or American history. The basis of the attacks of

${ }^{39}$ Cremin, Transformation, pp. $258-73$. 
E. Merrill Root are reflective (in simple but exclamatory fashion) of the underlying value structure that has prevailed in varted forms and debate throughout history: that the American Revolution was to emancipate the Individual, that the United States is not a democracy but a constitutional republic, that the good life comes from private initiative and that true freedom accompanies the wealth of the nation. 40 It is apparent that these are held in varying degrees by different people and that they are basic to any discussion of the soctal order of which education is a part. The teaching of the truth that Root talks about is of course structured around his rigid interpretation of what is truth. A later publication by Veritus Foundation in $1964^{41}$ alleged that creeping socialism was infiltrating the society through the educational system. John Dewey and the PEA were singled out as primary conspirators. But the basic question of indoctrination revolves around another question, when does the child accrue values and how? Recent statistical studies in political socialization show value accumulation of political items at a very early age (by the age of seven) ${ }^{42}$ and that socio-economic status of the community and school are active

$40 \mathrm{E}$. Merri11 Root, Brainwashing in the High Schools (New York: Devin-Adair Company, 1959), p. 13.

${ }^{41}$ Veritus Foundation, The Great Deceit (West Sayvi11e, New York: Veritus Foundation, 1964).

${ }^{42}$ David Easton and Robert D. Hess, "The Child's Political World," in The Learning of Political Behavior, ed., by Norman Adler and Charles Harrington (Glennview, Illinols: Scott, Foresman and Company, 1970), p. 42 . 
determinants of political orientation of its " roducts "43 Studies show that peer groups can alter value structures upward 44 and that civics classes at the senior level might in general have little effect on the average students' values or knowledge. ${ }^{45}$ studies of this nature provide evidence that other socializing influences are at work in society. The finding that a relationship between communtty social class and the political role a student is taught to play exists, would tend to support the conclusion that it is the values of the parents within the community that are being transmitted to the children. A question remains though as to the actual influence of the school with respect to other factors; peers, press, parents and other sources. Future studies will further determine how great a role the school plays in this process and in doing so, more concrete analysis of critiques such as by Root and Veritus Foundation will be able to be done. For it is a question of values that they allege are being indoctrinated and if the sources of those values can be identified the charges can be dealt with more expediently.

\section{${ }^{43}$ Edgar Litt, "Civic Education, Community Norms and Political} Indoctrination," in The Learning of Political Behavior, ed., by Norman Adler and Charles Harrington (Glennview, Illinols: Scott, Foresman and Company, 1970), p. 168.

${ }^{44}$ Kenneth P. Langton, "Peer Group and School and the Political Socialization Process," in The Learning of Political Behavior, ed., by Norman Adler and Charles Harrington (Glennview, Illinois: Scott, Foresman and Company, 1970), p. 162.

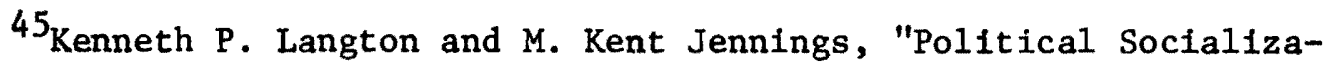
tion and.the High School.Civics Curriculum in the United States," in The Learning of Political Behavior, ed, by Norman Adler and Charles Harrington (Glennview, Illinols: Scott, Foresman and Company, 1970), p. 185 . 
Whereas charges from those of a more conservative political orientation would be centered around excessive teaching of liberal Ideas and values, similar types of charges have been advanced from what one could call a liberal orientation that the public schools are racist in their basic nature. 46 But charges which portray the issue of racism as merely a black-white confrontation in generalities tend to overlook the basic nature of the 1ssues acting on the realm of public education. Black parents want their children to be educated to enable them to become full participants in American society. Likewise white parents seek quality basic education for their children. Herein lies a potential conflict. Can both recelve quality education if either race within the school is of a different socio-economic class? And will the potential learning of the higher class be reduced by integration? A second aspect involves the values, morally and spiritually, that the children are introduced to within the schools. If both black and white parents seek to have their children attend public schools that emulate their perception of values, but one or the other perceives the other's values as lower or inferior, then another conflict arises. The parent who views his values in higher regard would tend to react against the influences that he sees on his children that do not reflect his own views.

The cases that describe attempts to integrate schools in New York City in the 1950's give evidence to this analysis. For all the

${ }^{46}$ Michael B. Katz, Class, Bureaucracy and Schools (New York: Praeger Publishers, 1971). 
good intentions to integrate, the politics of each situation governed the ultimate decisions. For PS 289 , it appears as though middle-class blacks appealed through the zoning office to prevent districting by which their children would have to attend schools with ghet to blacks. 47 Likewise in the case of JHS 258, it appears as though a coalition of black and white middle-class, real estate interests, and school officials defeated plans to integrate that school. ${ }^{48}$ The Kansas City case $^{49}$ showed a distinct plea from the black citizens to maintain high academic standards for their children and in the sense of values they supported a program of competitiveness to reach that goal.

The case of Bolse Elementary School in Portland, Oregon is an example of how perception of behavior in terms of values can create controversy in the schools. 50 In that case, remarks by the principal were held to be racist and slanderous. Stating that discipline was less in that school, that the language used by the students was often racy and that outrageous behavior was often tolerated, the principal became the target of attacks from the National Association for the

47 David Rogers, 110 Livingston Street, Vintage Books (New York: Random House, 1969), pp. 21-22.

${ }^{48}$ Ibid. , p. 21

${ }^{49}$ Martin Mayer, The Schools, Anchor Books (New York: by arrangement with Harper and Brothers, 1961), pp. 135-37.

${ }^{50}$ Controversy arising from newspaper interview with the school principal, September 24, 1973. See, B111 Keller, "Report card: Busing alleviates crowding, Boise school tensions," Oregonian, September 24,1973 , sec. 4M, p. 12 . 
Advancement of Colored People (NAACP) and embittered parents. But although his remarks were criticlzed, in actuality they appeared to reflect the true situation at Bolse Elementary. But, to suggest that the learning was less (than a reasonable standard) or that the level of values as displayed by behavior was less than the respectable middleclass norm, was to the parent of a Bolse Elementary child, an assault on the values of that parent.

A study of the status of Negro educational attainment in $1961^{51}$ suggested that in some geographical areas that the Negro was worse off In 1961 than he was prior to Brown-versus-Board of Education in 1954. The study was challenged by unbelleving blacks. To claim that the Negro had regressed rather than progressed offended their status in the soctal order. One, recognition that the Negro had to achieve minimum levels in educational basics to improve his place in the American social order and further cognizance that he had indeed regressed in many selected areas was a bitter truth. And the possibility of ralsing doubts of Negro intelligence and abilities about his motivation and drives, through such a study incensed his sense of progress. The accuracy of the study, however, was borne out by the very statistics and examples used. The famfliar aspects of perception of progress through educational basics (in this case basic achievement) and of the values held by the critics in the controversy can be seen as principal agents of discord.

$51_{\text {Nationally syndicated award-winning series. See, Dr. Walton }}$ Manning, "Education and the Negro," Mlami News, September 22-25, 1961. 
Similarly, of one views the area of educational alternatives, the matter of content in education becomes paramount. The ghetto resident has been unable to escape the traditional nature of the urban public school because of lack of funds and because of the lack of alternatives. But the 1960's spawned a revival of interest in the content of education, in new private alternative schools and in the public domain. In both realms, the aspect of content is inseparable from the aspect of values. In seeking educational alternatives, parents apply a subtle pressure to the public schools. Since the existence of the public school is through the support of the parents, then if the parents advocate alternatives, the school must respond if the alternatives appear to have popular support. The option of the parent is to generate criticism to produce change or seek alternatives to public education.

The alternatives sought by parents can range from freedom at large to a strict disciplinary atmosphere, in terms of values for example. The alternatives sought in terms of educational content can range from the "three $R^{\prime} s "$ to an elaborate skill training curriculum in the arts and crafts. Jonathan Kozol attempted to make a clear distinction of values in his discussion of the content of education. 52 For the poor, urban, ghetto dweller, basic educational content of reading, writing and arithmetic may well be a path from an unhealthy, perilous environment to a better life. Parents who seek such

52 Jonathan Kozol, Free Schools, Bantam Books (New York: by arrangement with Hought on M1fflin Company, Boston, 1972). 
alternatives recognize the inflexibility of the educational system as 1t is. The tendency of the public school to operate as though it existed in a political vacuum and hence be unresponstve to the spectal needs of the black, urban, poor is evidenced by the trend to alternative schools. However, it is not only the urban, poor, black children that seek alternatives. Increasing enrollments of children across the United States in church-sponsored schools are being noted. 53 If the public school is not able to provide an environment with values that a parent can agree with, he can register his objection in many ways, one of which the alternative school is becoming an increasingly popular means.

In the public sector though attempts have been made to modernize the public schools. New approaches and new techniques, entirely new criterion for progress, and alternative curriculums have been attempted. John Adams High School in Portland was a venture of this sort. 54 But

53"Boom in Protestant Schools," U.S. News and World Report, LXXV, No. 15 (October 8, 1973), pp. 44-46.

54 Robert B. Schwartz, "Profile of a High School: An Introduction," Phi Delta Kappan, LII (May, 1971), 515, also see

Allen L. Dobbins, "Instruction at Adams," Phi Delta Kappan, LII, (May, 1971), 516-19.

Patricla A. Wertheimer, "School Climate and Student Learning," Ph1 Delta Kappan, LII (May, 1971), 527-30.

John L. Parker, "Teacher Training at Adams," Ph1 Delta Kappan, LII (May, 1971), 520-22.

"The John Adams Team," Ph1 Delta Kappan, LII (May, 1971), 514. 
the experimentation at Adams proved one very important thing, it is extremely difficult to employ Innovation such as they were attempting In such a large public school. The history of such attempts in the experimental schools of the progressive period had already shown that an experiment of the nature of Adams was unlikely to produce any startling achievements. As it developed it suffered through much critictsm for lack of disclpline and rowdiness and at last reports had had to modify its liberal, self-motivating format to an optional traditional curriculum for those who desired $1 t .55$ The offering of the optional traditional curriculum might be construed as a means of "reaching" those who were unable to cope with the freedom of the original system or It may also be in response to parental criticism who sought a more disclplined learning environment for their children. In view of the nature of parental criticism, the latter reason would seem to predominate. The parents responded with an appeal for a more rigid form of school, one which in all 11kelthood resembled their conception of child-rearing and its inherent value system.

In a broader sense then, alternative education, whether in the private or public sector, will indeed have a tendency to reflect those values that the parents wish to have their children learn. And as a continuation of that theme and intertwined with $1 t$, the content of that education will be reflective of the value system of the parents.

55 Recognition must be given to the parents in all likelihood for efther promoting this change or for their role in child-rearing which demanded a more traditional form. 
"The School" as a Responsive Political System

Easton's model as described in Chapter 1 and shown in Figure 1, is a form that could be employed in any varlety of political systems. Because of this, the nomenclature it is described by tends to be general In nature and because of this, development of the nomenclature to a more specific form is desirable if one is to observe a particular system. The realm-of education can be looked at in a variety of ways. A particular local school system could be viewed as a system itself or a state system might be seen as one political system unto 1tself. In the former case one would have thousands of systems whereas in the latter one would have as many as states existed. St111 another manner to approach the problem is to view education as an overall system, national in scope, even though school systems attempt to maintain an emphasis on local control. In terms of the objectives of this thesis the framework provided by the largest possible scope, one of national basis, allows discussion of a wide varlety of concepts and 1ssues that might be somewhat restricted by a narrower scope. If one considers the development of education from the mid-1800's to the early $1900^{\prime} \mathrm{s}$, an increasing acceptance of public schools can be noted. Along with this an accent on the national with development of transportation, communication and Information systems 1s apparent. In an attempt, then, to observe the themes or common threads in "the school" as a general political system, the largest of the frameworks discussed here, that of a national scope, will be employed. This, however, does not limit the perspective to merely the national level. Since the emphasis of this thesis is to 
Identify general aspects and themes that are common tó controversy in education and the public schools, then these aspects would indeed be applicable to a given local or regional situation. It is from this standpoint that the following model is constructed. Moreover, from the standpoint of Easton's "Dynamic Response Model of a Political System,"56 it is apparent that the nature of this thesis primarily directs itself to a discussion of what Easton calls "Demands". "Outputs" are of prime Importance to the model but 1 is the perception of these outputs through various forms of feedback, by various interest groups, parents, pressure groups and a multitude of other organizations that create a distribution of support (pro or con) for the given system. This distribution of support may be developed in many ways and through many facades. It 1s, however, one of the intentions of this model to concentrate on the form of the demands with an intent to determine how the themes and general aspects previously identifled, act in the model. Figure 2 depicts a political system with outputs. In this case the outputs are various. Seen by political scientists it might be viewed as a prime agent by which the young are socialized politically. Seen by an educator it might be viewed in various views, one of "pure" education, one of instilling values, one of helping the young to get a job and prepare for the future, or even of create good citizenship. Seen by other agencies in the public realm it might be seen as a monopolistic institution in the public good, yet primarily with an

56 David Easton, A Systems Analysis of Political Life (New York: John Wiley and Sons, Inc., 1965), p. 30. 


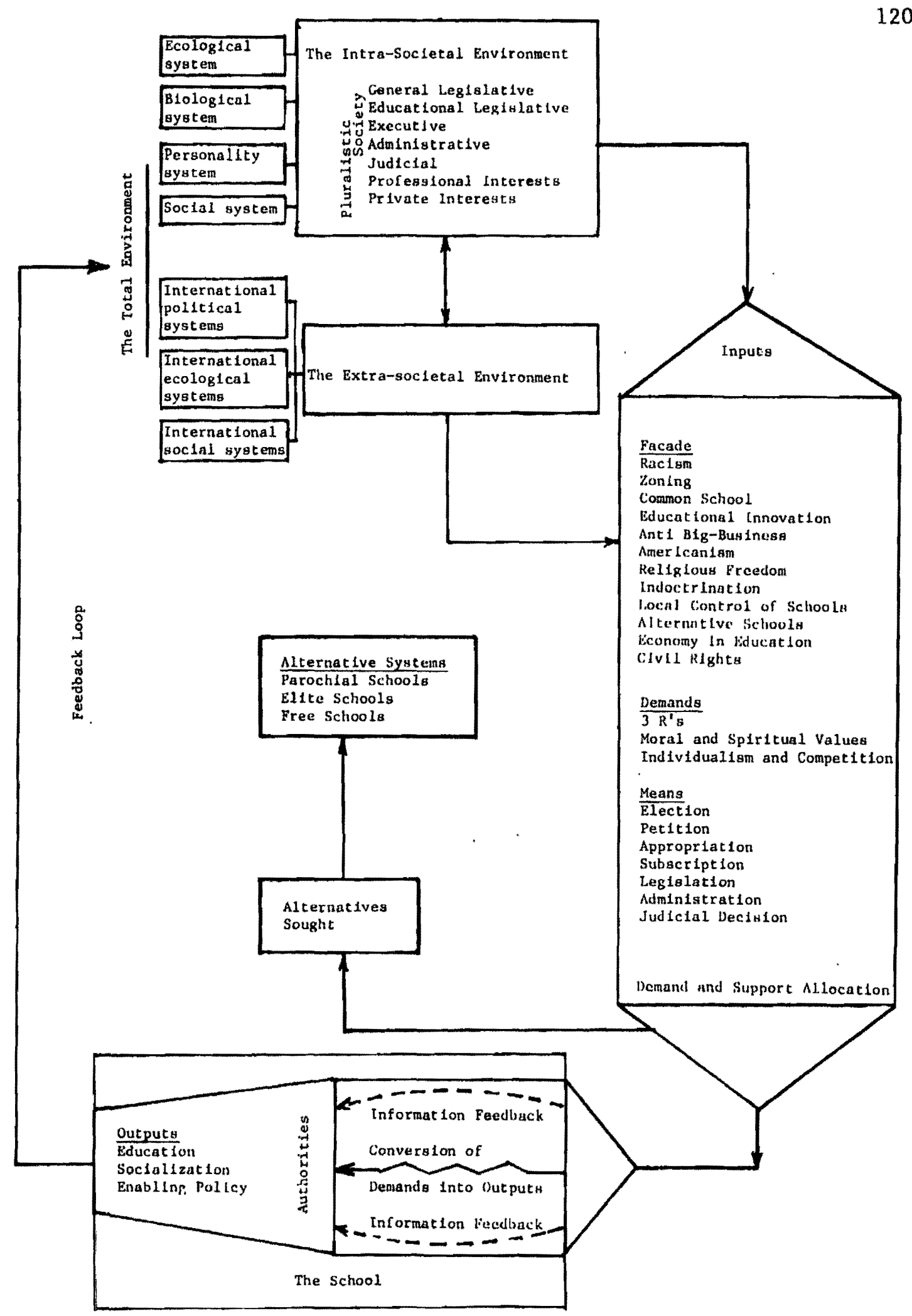


emphasis on costs and return. Yet the primary product is the education of the young, even though it may come in a variety of forms and under varying circumstances. One might measure it in terms of attitude development, change in political orientation, ability to score well on achievement tests, ability to get jobs once out of the system and many more. Still other forms of policy output might be generated as policy output to fulfill the "ends" for which the school exists. These policles might be zoning and districting, racial balance, assessment and others. If one were to attempt to classify outputs, three groupings might be constructed: education, socialization and enabling policy.

To then view the feedback loop as shown in Figure 2, it can be seen that it routes the effects of all outputs back to the environment. In this fashion the results of all three categories of outputs can be seen to act upon the environment and through it, altering or solidifyIng the distribution of demands and support. This is simply observable in that all three categories, education, socialization, and enabling policy, have potential far reaching effects on the environment that supports "the school" in the United States.

The environment which Easton has constructed in general terms recognizes the international as well as national environments. As he calls them, extra-societal and intra-societal environments. With full recognition that the extra-societal environment plays an increasing 
role of importance in "the school" as a political system, 57 no detailed discussion will be made here, although the interplay between the intra and extra realms must be noted. The intra-societal environment is a complex, pluralistic form (as developed here) which incorporates the four elements that Easton presents: ecological systems, blological systems, personality systems and social systems. To simplify this then, the intra-societal environment is depicted as a multitude of interest groups and pressure groups that create an environment through which a distribution of demands and supports are made. Also, whereas Easton chose to separate intra and extra societal environments, only to meet at his input gate, recognition of the interplay between these two environments might be made clearer by depicting a relationship by arrows between them. This then takes into account the effect of the extra-societal environment prior to becoming input. In observing the intra-societal environment in Figure 2 with the variety of interest groups shown, it must be remembered that this is only suggestive of the possible groups in a pluralistic society, because doubtless, there are many more. 58

Inputs are then given to the so-called conversion process in the form of demands and supports. And it is to the area of demands that

57 i.e., the curricular emphas 1s on science after the launching of Sputnik or the variety of modifications to curriculum content and behavioral standards with the highly emotional period of the Viet Nam War.

${ }^{58}$ Accrediting agencies, foundations, parent organizations, speclal taxation groups, special counsels, etc. 
this study is primarily directed. In analyzing the controversies as developed in this Chapter, what was being attempted was to observe the true nature of the demands being made upon the political system, "the school". Figure 2 adds another level of classification prior to demands, Facade. 59 The 1tems which are 1ncluded under the heading Facade are issues which have been found in this study of "the school". They cover a wide range of topics and are complex issues. But what is suggested here, and is implied by the heading is that the issue is merely a facade and not really the prime demand in terms of "the school". The prime demands as developed through controversy or other means have been reduced to three demands: the desire of the people to have all children successfully master the basic fundamentals of reading, writing and arithmetic, - $3 \mathrm{R}^{\prime} \mathrm{s}$; the desire of the people to have schools emphasize moral and spiritual values which were similar to their own -- moral and spiritual values; and the opposition of people to what was belleved by them to be an attempt by the school to foster some dimly defined kind of socialistic theory which would replace Individualism with group goals and competition with cooperation -- individualism and competition. The facades however are far greater in number; racism, zoning, common school, educational Innovation, and anti big-business, Americanism, religious freedom (separation of church and state), Indoctrination, local control of

${ }^{59}$ With no intention of creating additional jargon, facade is used purely as a matter of convenience. The intent is to indicate that the issues 11sted under 1 t are easily recognized by external characteristics whereas their true nature is based upon the three identified themes. 
schools, alternative schools, economy, and civil rights. The issues which could be raised are far greater in number than these, but for purposes of this thesis, they 111ustrate what is intended, that issues In public education tend to revolve around these three basic demands. Support is seen then as a distribution of support (or lack of it) for what it views a proper or improper behavior on the part of "the school". And although a controversy or issue can be categorized in terms of events or other characteristics, the basic demands in terms of values still seem to prevail. In 1ts quest for continuance, "the school" attempts to garner support. Easton suggests that specific support might be sought over a specific issue, or that diffuse support ${ }^{60}$ might be relled upon, which might take the form of a basic faith in "the school". The means by which the process of support obtalns is various: election, petition, coercion, subscription, legislation, administration, judicial decisions and more. It is the vast complexity of the soclal order operative in a pluralistic environment that consistently feeds input into the conversion process. The process of conversion, with recognition of the distribution of support, may ignore the demands of an issue, or it may rely on diffuse support, or as a third alternative it may change the system itself in order to again aggregate sufficient support to assure its continuance. 61

${ }^{60}$ See V. O. Key's discussion of latent public opinton, V. O. Key, Jr., Public Opinton and American Democracy (New York: Alfred $\Lambda$. Knopf, Inc., 1961), pp 263-87.

61 These are only suggested reactions. Undoubtedly they would tend to be complex in nature. 
The feature of Information feedback allows "the school" as a political system to observe demands, supports and output in the process of conversion. And through this feature it can adjust its policy goals, and other aspects of its realm to accommodate demands and levels of support. As the conversion process is then complete, the output is then seen as feedback to the environment as a new cycle begins.

As long as the stress introduced into the system is below a level which would redistribute support unfavorably, the system w111 continue to exist. However, if elements of support become alienated or have demands that are unobtainable within the system, and if the system still has aggregate support for its policies, then those alienated must seek alternatives elsewhere or alter their perceptions and expectations. If the lack of support through such mechanism becomes great enough then the system must either change or suffer possible extinction. If the system can maintain sufficient support yet is not able to satisfy some demands, then those whose demands are not being met may construct a new system. In the case of the public school the alternative becomes the parochial school, the elite school, the free school or other forms of alternative systems. And these in turn become systems unto themselves with behavior patterns similar to those of the system described herein. 62

To fudge the adequacy of the model, "The School as a Responsive Political System," one must observe the given system over a period of

${ }^{62}$ And these systems then respond to their own environment with their own special publics. 
time, and although this does not evolve any rigorous proof or universality in the model, it would serve to support the model for this particular study and for its limited time frame-- from the popularization of education as a trend in the mid-1800's to the present.

The first part of this analysis was devoted to identifying the issues involved in various controversies in the schools and to further ascertaining the true nature of the demands involved in the various situations. This, of course, to Easton's model (Figure 1) or to the developed model of the school (Figure 2) serves as the pivotal arena for development of change in the system, in terms of output, system adaptation and modification, or system elimination. In the case of "the school", the latter alternative might assume the form of loss of patronage through the selection of alternative systems even though the levels of support and their distribution would still affect the primary system. These demands though serve as potential agents to stress a given political system ${ }^{63}$ Easton distinguishes the political system from others by two characteristics.

They must be able to allocate values for a society; they must also manage to Induce most members to accept these allocations as binding, at least most of the time. 64

In terms of the models discussed, if the levels of support drop off for a given system and the demands increase, then the system must respond In order to maintain acceptance. The reaction of the polftical system

63 David Easton addresses himself to all manner of forms in which stress may occur in a given political system. See, David Easton, A Systems Analys ts of Political Life (New York, John Wiley and Sons, Inc., 1965).

${ }^{64}$ Easton, Systems Analysis, pp. 23-24. 
can be varied and the stress may be found in many forms with differing aspects--content, time, volume of demands, type of demands, and levels of support. All the variety suggested by this can be found in a study of "the school" as a responsive political system. "The School" has responded, in different ways to different issues and demands. It is suggested, however, that the basic nature of the demands, in terms of the three values constructed in this thesis, has had the effect of establishing a broad base of support, diffuse in nature, which has given "the school" great latitudes within which to operate. The following will briefly trace, comparing demands to change, readjustment and reaction within "the school" as a political system. And although specific in-depth analysis is possible for each controversy within this thesis, data permitting, this will not be attempted here. What will be attempted is a brief observation of the demands and other characteristics of the model as they have acted upon and demanded changes within the system.

Negro education in Alabama showed a system severely stressed by racial demands, demands that assumed a diversity of forms and distribution of support over a 25 year period. Nonetheless, the demands begged educational policy that was more "white-oriented" and the system responded. Legislation, judicial decision, and politics in general enabled constitutional changes to allow the school system to respond to stresses placed on the system. 65

\footnotetext{
${ }^{65}$ Bond, Alabama.
} 
The issue of trade school education proved to be an issue that was vigorously supported by some and held in disdain by others. Public education had its option, was it to offer industrial education or agricultural education or did it view them as being outside of its purview. For several years the issue was hotly debated, but a gradual acceptance of the form was seen. The basic issues were founded upon the $3 \mathrm{R}^{\prime} \mathrm{s}$ and moral and spiritual values. But, the distribution of support gradually improved, with "the school" ultimately making trade school education an accepted adfunct to traditional education. The stresses placed upon the system found gradual reaction until the perception of outputs finally agreed with the demands and distribution of support.

The trend to a non-sectarian form of education in the public school was almost a condition of the construction of a system of public schools. To this day, this trend has persisted and in doing so, has given a greater level of diffuse support to "the school" as a public institution than many other institutions enfoy. From time to time issues relating to religion do appear to stress a system. If the public school is unable to satisfy the demands, alternatives can be sought. And although a system may be stressed in this manner and by issues of this nature, the public view of separation of church and state has given "the school" a high degree of support. Looking at the Progressive (reform) era, one can view two simultaneous movements acting upon the educational system: One, a trend toward bureaucratization in the schools and a general removal of schools from the political arena and two, a trend toward the child- 
centered form of education, sometimes called progressive education. The first affected not so much the demands made upon the system in terms of output, but primarily, the levels of support and their distribution for the given system. Systems were stressed though, as one can observe by the McAndrew controversy in Chicago, 66 but the result in terms of system adaption and change was similar to those found in municipal reorganization and reform: a greater concentration of control in the hands of the elite and professional classes. Concurrently "the school" was being pressed to consider new innovations In education. Alternative schools were increasing in number which had the potential for reducing public school support, "the school" responded to the stress and Incorporated elements of the new innovative programs into the public school. The inclusion of platooning, certain forms of child-centeredness and aspects of project oriented curriculum assured "the school" of maintaining adequate levels of support and minimums of stress.

The assertions made by George Counts and others in the depression brought public education into sharp public focus. Should the schools build a new social order was the question of the day. To suggest this was to suggest that "the school" arbitrarily alter its course, not necessarily even with a perusal of the distribution of support. Counts was primarily concerned with the output, but to suggest that it be altered without concerted analysis of the distri-

${ }^{66}$ Counts, School and Society in Chicago. 
bution of support created skepticism among his colleagues. "The school" would be unable to maintain adequate levels of support and his colleagues knew this. And although this is not to suggest that elements of what Counts promoted did not get injected into the public school system, more recent criticism charge that they did.

What might be considered "right-wing" attacks on leftist oriented textbooks, in the post-World War II period and after, altered levels of, support and their distribution across the United States. Although external events (cold war, Korea, etc.) might have accounted for many of the demands upon the school, the diversity, bureaucratization and "political remoteness"67 of "the school" has left it in a condition where diverse support allowed the basic nature of "the school" to operate. The post-World War II attacks can be seen as having complex demands, yet the controversies in themselves, while creating stress on individual systems, did not by and large remove this diversity of support or drastically change the nature of the output of the school. Judicial decisions of the 1950's and 1960's, however, have created various changes in levels and distribution of support for "the school". The issues of race (moral and spiritual values) has confronted all elements of society and the resulting stress on "the school" could only be called magnitudinous in nature. Concurrently, increasing demands for change in the nature of the schools are being

67political remoteness is suggestive primarily of the striving for non-accountability of "the school" and its plea for privileged, independent and professional status. 
asked for by varfous elements of support. The school is being asked for special programs, scme more basic and some with more variety. It is belng asked for a different emphasis on outputs by some. If one looks to the increasing numbers of alternative programs within the school, this might be viewed as adaption to demands...stress upon the system. But the increasing numbers of alternative system outside of "the school" leads one to belleve that this represents a loss of support for "the school" in general.

"The school" in the United States is attempting to regain certain levels of support that it has lost in recent years. This is more accented in some areas but the trend is mounting. Since its inception "the school" had adapted to stress situations in such a way as to promote its continuance as a viable political system. And whereas its remoteness and diffuse support in the past have rallied to help reduce stress conditions, it may well be that this "political remoteness," if not checked, may be an agent of support loss. With increasing attention to minorities, which in the past had been an unheard element of the diffuse support, it is obvious that if the schools are unable or unwilling to satisfy the demands of this important element of support, then additional stress will be placed upon the system, with potentlal fallure.

The history of public education, then, can be seen as one of change, adaption and modification. It is obvious that the outputs have changed: different types of education, changing socialization, and new and different forms of enabling policy. And to accomplish these various outputs "the school" has had to adapt to its inputs: demands 
under various facades and support through various means and distributions. What is striking though is that although the intra-socletal environment and extra-socletal environment with the aid of feedback determine the nature and distribution of demands on "the school", that the basic nature of the demands guiding the determination of school output break down into three basic aspects: $3 \mathrm{R}$ 's, moral and spiritual values, and individualism and competition. Furthermore, it appears that if education seeks to persist as a viable political system that it will have its greatest success if it can accurately analyze the basic nature of the issues confronting $1 t$, in terms of these three aspects. 
In approaching any study of education and politics, one is immediately confronted with a plethora of limitations which make any concise anlysis of education and politics, in a broad perspective, very difficult. The lack of any specific and comprehensive data sources, the broadness of the realms of education and politics, and the accuracy of the various sources of data are but a few of the limitations. In spite of these limitations, an approach was sought to examine a variety of cases and situations where controversy was widely reported (or accurately reported in an acceptable source). These cases and situations would then be analyzed in an effort to extract themes that would concelvably be common to any controversy In education in a political environment. By approaching the topic In such a manner, themes could be Identifled which have persisted throughout a variety of Issues and over the span of public education In the United States. ${ }^{1}$ With the themes Identified, a general model of "the school as a responsive political system" could be developed

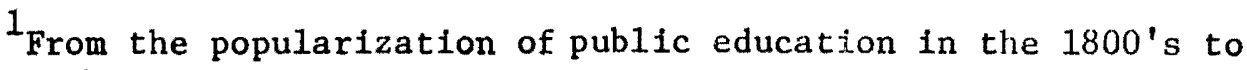
the present. 
through the systems model employed by David Easton. 2 And although the prime thrust of this thesis is the development of the various themes, the framework provided by a hypothetical political system gives a general context in which the themes can be observed.

It was felt that such an approach would provide a means to assess the complex realm of public education and politics. The model that Easton suggests is portrayed as a system, responsive to output from the system, which returns and affects the system through a feedback loop. Accordingly, the environment is seen as acting upon the system by creating demands upon it and by developing various levels of support for the system and 1ts objectives, Its policy output and other outputs. The polftical agency then acts upon the demands to produce outputs through a process called conversion. It is here that inputs are converted to outputs. This system then, while used primar $11 y$ as a framework to view education as a system, allows one to observe the true operative nature of the themes and their relationship to vartous issues. It further allows education to be observed over any time period and under any circumstances to better understand issues, trends and the fashion in which "the school" reacts.

Cases and situations were chosen on the basis of one criterion: the avallability of material about the cases or situations in terms of quantity and quality to permit scholarly analysis. After the selection

\footnotetext{
2David Easton, A Systems Analysis of Political Life (New York: John Wiley and Sons, Inc., 1965), p. 30 .
} 
of cases, a detailed description of each case and situation was given. Following the description of each of the cases, it was recognized that regardless of the issues involved in each case, certain themes were consistently present. These themes are:

1. The desire of the people to have all children successfully master the basic fundamentals of reading, writing, and arithmetic.

2. The desire of the people to have the schools emphasize moral and spiritual values which were similar to their own, and

3. The opposition of the people to what was belleved by them to be an attempt by the school to foster some dimly defined kind of socialistic theory which would replace individualism with group goals and competition with cooperation. The cases were then described in terms of these three themes.

The first case, entitled "The New Black Citizen in Education", discussed the gradual disenfranchisement of the Negro politically and educationally in Alabama from before the Civil War until the early $1900^{\prime} \mathrm{s}^{3}$ Gradual legislation to promote the shifting of the tax base was analyzed as a means to.improve the quality of white education and as a means to further soclalize white children with white values. Racism was discussed as the vehicle by which the white Alabaman was able to Increase the quality of white education and promote the white value structure.

${ }^{3}$ See Chapter II, page 12 , Chapter III, page 85. 
The emergence of trade school education and skill training as an integral part of public education were discussed. 4 The emergence of the United States into an Industrial nation demanded that people be trained to participate in the economy. The debates which continued for several years are shown to be argued primarily in the areas of the soundness of baslc education and in terms of moral and spiritual values of those debating.

Another group of cases was combined into a section called "An Experiment in Progressivism". 5 Dealing with the Progressive Era in education, it viewed public experiments such as the Quincy System in Quincy, Massachusetts and the Gary Plan of Gary, Indiana as well as experiments in the private sector such as the Dewey's Laboratory School, the Organic School In Alabama, Lincoln School at Columbia, Porter School and others. Advocates saw child-centeredness as a tool for greater learning while critics saw a conspiracy of sorts to weaken the strong disclpline noted in the period and to subvert the youth. All three themes Identifled in this paper appear in a discussion of the progressive movement in education.

The reform period as well as the depression had unique influences on the realm of education. One such case was described in "From Reform to Depression".6 The case related the firing of the Chicago superintendent of schools, William McAndrew, through the efforts of the newly elected mayor who used his removal as a pledge

${ }^{4}$ See Chapter II, page 20, Chapter III, page 87.

5 See Chapter II, page 23, Chapter III, page 89.

${ }^{6}$ See Chapter III, page 32, Chapter III, page 95. 
In his campaign. The analysis is lengthy and complex and has elements of each of the themes identified in various issues throughout.

Another section entitled "The Red Scare--Post-World War II" described and analyzed cases which occurred in Denver, Colorado; Port Washington, New York; Eugene, Oregon and Pasadena, California. ${ }^{7}$ Common to the first three were attacks by parents that the basics were being ignored. In addition, the Eugene case claimed that not enough discipline was given to the children. Charges of un-Americanism was also present in each of the cases. The Pasadena case involved all of these elements and more. While the first three cases were resolved in part by surveys and study groups, the Pasadena case was far more complex and drawn out. Ending in the removal of the superintendent of schools, the system was put into a state of uncertainty. Many issues were analyzed as being responsible for the situation, and all of the three themes identified were shown to be present. Reaching further back in time, a section entitled "The Roots of Public Education" looked at controversy present in cases in New York and Massachusetts when a trend toward nondenominational public schools demanded that certain religious teachings be suspended from the curriculums. 8 The need for public schools was seen in 11 ght of vast Immigrations and the need to Americanize the new immigrants. The basis of the controversies was seen to revolve around conceptions of

${ }^{7}$ See Chapter II, page 41, Chapter III, page 100.

${ }^{8}$ See Chapter II, page 53, Chapter III, page 105. 
moral and spiritual values.

The Influence of the Great Depression on education was described in a section entitled "Dare the Schools Bulld a New Social Order".9 The essence of this section revolved around George Counts and the Progressive Education Association (PEA). The viewpoint of Counts as well as those of other social critics of the period viewed the form of capitalism produced by the United States as an obvious failure as evidenced by the economic collapse. In reaction, his call for education to be more responsive in teaching social awareness for the welfare of the masses was viewed as one reason for the failure of the PEA. And for these reasons this situation was interpreted as basically composed of two themes: moral and spiritual values alien to traditional American values and a fear of a form of socialistic orientation to be promoted by the schools.

Later criticisms of John Dewey and the PEA were found in right-wing publications such as those of E. Merril Root and Veritus Foundation and were described in a section entitled "The School-Charges of Indoctrination".10 These attacks on the schools in general, the textbooks, and teachers in the 1950's and 1960's were seen as belng basically a debate over moral and spiritual values and fears of liberalizing the schools in a socialistic manner. Comparisons of these attacks with some of the more recent findings in political

${ }^{9}$ See Chapter II, page 58, Chapter III, page 108. ${ }^{10}$ See Chapter II, page 62, Chapter III, page 109. 
socialization were made which attempts to Identify the nature of some of the accusations.

The question of Negro education in recent times was discussed in a section ent1tled "Black and White Education -- Separate and Unequal."11 Two cases were cited from New York C1ty in the 1950's and the 1960's as well as one from Kansas City in 1954. Each Involved the question of the quality of basic education and the transition from a segregated form of school to an integrated form. Another case taking place in Portland, Oregon at Bolse Elementary School in 1974 found the principal of this lower middle-class black school charged with racism and other offenses. On a broader base, a study of the status of Negro education published in 1961 was discussed in view of the controversy it generated. It was concluded that each of the controversies and cases mentioned in the above revolved around moral and spiritual values and various peoples' perceptions of them. Secondly, it was concluded that the element of quality of the basic education was also a predominate factor.

In a section entitled "Educational Alternatives--Threat to Tradition", free schools, alternative schools, new curriculums, and educational innovations were discussed.12 Specifically, free schools of the type described by Jonathan Kozol ${ }^{13}$ were reviewed as well as

\footnotetext{
${ }^{11}$ See Chapter II, page 69, Chapter III, page 112.

${ }^{12}$ See Chapter II, page 76, Chapter III, page 115.

13Jonathan Kozo1, Free Schools, Bantam Books (New York: by arrangement with Houghton Mifflin Company, Boston, 1972).
} 
some found in the public sector such as John Adams High School in Portland, Oregon. The Implementation and suggestion of various alternatives and programs in public schools were discussed and subsequent reaction to them were viewed in terms of quality of the basic fundamental education and in terms of parental values, moral and spiritual. Varlous public school programs were seen as an effort to satisfy a certain segment of the public whereas much of the objection to these same programs was seen as coming from other critical parents attempting to preserve their own moral and splritual beliefs or their conception of a basic fundamental education. In the private sector alternative schools were seen as havens for those, evermore in frequent numbers, fleeing from diluted or distorted education and desiring that values to be taught to their children which were similar to their own.

After the cases and situations were discussed in terms of the three identified themes, the themes were then applied to a model of "the school as a responsive political system." Modeled after David Easton's "Dynamic Response Model of a Political System", 14 the model was constructed with an emphasis on the nature of the issues causing stress in the system. And the nature of the issues were held to be the themes Identified by analyzing the cases. In terms of the model, the tssues themselves were held to create a certain distribution of

\footnotetext{
${ }^{14}$ Easton, Systems Analysis, p. 30.
} 
support for the political system. ${ }^{15}$

Generally, the system developed considered three basic outputs from the system: education, socialization, and enabling policy. And all three types of outputs were seen feeding back through a series of feedback loops to an environment which was seen as complex in nature. Viewed as a combination of intra-societal and extra-societal aspects, it was shown to be pluralistic in nature. All elements were seen as feeding input through input gates to ultimately be acted upon (or not acted upon) hy "the schoo1". At the input gate though, the 1ssues were described under a category called facade. It was held that these may be racism, zoning, common school, educational innovation, anti-big business, Americanism, religious freedom, indoctrination, local control of schools, alternative schools, economy in education, civil rights and more. However, as was the intent of this thesis to Identify themes common to controversy in education and the schools, it was held that these issues under these facades were all basically of the nature of the three 1dentifled themes: $3 \mathrm{R}^{\prime} \mathrm{s}$, moral and spiritual values, and Individualism and competition. Furthermore, it was held that regardless of the changing issues from one period to the next, these basic demands (and the perception of them by parents) have served as the basis for controversy and change within the system.

Auxiliary to this facade and the actual demands (the identified themes) were the means of allocating a distribution of support. It

${ }^{15}$ See Figure 2, "The School as a Responsive Political System", Chapter III, page 120. 
was suggested that support allocation is extremely complex due to the pluralistic nature of American society, but that some of the primary means of distribution are: election, petition, appropriation, subscription, legislation, administration, and fudicial decision. As the distribution of support is viewed by "the school" it converts the demands it sees into the outputs which have previously been called education, socialization, and enabling policy.

In reacting or taking action "the school" has any number of options, but its interest is survival. That is, its primary goal is to assure its continuance. In order to provide this support it reacts variously to input demands. If the demands cannot be met by the system, alternatives can be chosen by varfous people or publics. Should support decline to too great an extent the system would be in peril of fallure.

In an effort to show how the three themes have acted to stress the system and how the system has reacted, a brlef discussion of "the school as a responsive political system" was undertaken. The demand for improved "white-oriented" education in Alabama was seen as a response to demands upon the system even though it took over 25 years to accomplish it. The addition of trade school education found gradual acceptance among the public and corresponding acceptance by "the school". The separation of church and state, almost a condition of the public school, has provided a broad base of support for the school. In the progressive era removal of the schools from the political arena was heartily supported by the public. Concurrently, the Introduction of child-centeredness found strong objection, at first 
creating stress on the system, but as gradual acceptance became apparent, "the school" gradually adopted aspects of the movement. The promotion of social awareness that George Counts debated was shyed away from by "the school". Recognizing public reaction would be negative, and in order to preserve support, the schools would not acknowledge his "dare". The red scare period after World War II was seen as one of turmo11, but also one where no real loss or gain in support could be seen. Creating stresses of far greater magnitude were the clvil rights decisions of the 1950's and 1960's. The Involvement of other special publics ${ }^{16}$ who were previously outside the more important elements of support now have a voice. And in such a state the status of those already included as the most important elements of support are seen as threatened. New demands by both elements w111 create more stresses in the school. New Programs and new Innovations are being adopted to reduce this stress situation, all with an Intent to secure the continuance of "the school". In viewing "the school as a responsive political system" it was concluded that if education does seek to persist as a viable political system that it will have 1 ts greatest success if it can accurately analyze the basic nature of the issues confronting it, In terms of the three Identified themes suggested.

16 Minorities. 


\section{RECOMMENDATIONS}

"The School"

If the school desires to maintain maximum support among the electorate, it must satisfy each of the demands as described within this thesis to varying degrees. Furthermore, if the "the school" can satisfy the demands that are voiced in terms of teaching the $3 \mathrm{R}^{\prime} \mathrm{s}$, the demands that are developed in terms of moral and spiritual values and In terms of individualism and competition, it will have less significant effects on the system. The parent looks to the school first and foremost for its accomplishments in terms of measurable outputs. In the case of the school, this represents ratings in terms of scores on standardized tests in comparison to other local, regional, statewide, or national scores. If the school in a given area can boast high ratings on achievement in the academic subjects, then it would be expected that considerable more latitude would be given to the students in terms of exposure to moral and spiritual values, and in turn to various political philosophies and doctrines.

Secondly, if the school is able to produce high levels of standards in the basic subjects, then difficulties and turmoil with segregation as an 1ssue within the school would be minimized. For this reason the school should have as its primary goal, the teaching of the baslc academic subjects that are so necessary to equip youth to seek a place in the social order. This is not to suggest that segregation Is a desirable goal, but it does recognize the turmoil and stress on the system and on the students within the system. 
If the school is to maintain the support that it has come to take for granted, it must be able to recognize and satisfy the multifaceted public which it exists for. Recent defections to alternative schools, church schools, free schools and other forms suggest that some of the demands made by those publics are not being met. Why? Either the denands have gotten more diverse and complex or the course that public education has taken in recent years has not met the essential and the primary demands of the parents. Recent articles in a variety of publications suggest that the issues have become more complex but that the schools have deviated in many respects from the true demands of the parents. Titles such as the following suggest a recognition of the true nature of the demands: "Schools To Stress ' 3 R's'"17, "Why Can't Johnny Calculate?"18, "Once-heralded method of teaching figures doesn't seem to add up"19, "Are We Becoming a Nation of I111terates?"20, and "Arizona bids to bring back education even if it sets liberal factions twitching". 21 For these reasons it is suggested that a

17"Schools To Stress ' 3 Rs"', The Oregon Journal, September 7, 1973, p. 2 .

18 "Why Can't Johnny Calculate?," The Oregon Journa1, October 20, 1973, p. 8.

19 "Once-heralded method of teaching figures doesn't seem to add up," The Sunday Oregonian, October 21, 1973, p. 10.

20Vance Packard, "Are We Becoming a Nation of Illiterates," Readers Digest, (Apr11, 1974), CIV, pp. 81-85.

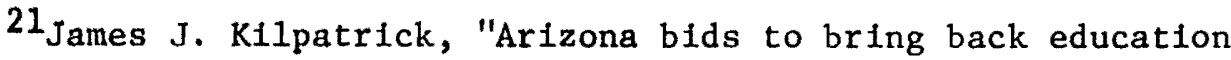
even if it sets liberal factions twitching," The Sunday Oregonian, January 20,1974 , p. F3. 
serles of courses be taught within the discipline of education that would better allow the student to understand how "the school" fits into a totally political society and to allow him or her to function more effectively when active in the areas of public education. For future administrators such a course of study is a must; for the teacher it could certainly be considered vital.

\section{Political Science}

Political Sclence should produce more concentrated study and instruction in the field of education. Recognizing the amount of time in years that an individual invests in education, the amount of money that is pald into taxes annually by citizens, and the total amount of employment generated by education and education related activities, it readily becomes apparent that education, as a fleld of study, has not recelved an approprlate amount of attention by political scientists. Political socialization, in terms of schools, has undergone much development in recent years. Yet research into many of the other areas of the schools is notably lacking. The limitations suggested by this paper are no doubt responsible for some of the lack of act1vity but one must also look to the lack of esteem that education has generated among many social scientists in recent years. Regardless, the Importance glven to education in the United States by the citizenry is sufficlent in itself to warrant greater studies into education by political scientists.

Specifically and directly relating to the findings of this thesis, the following suggestions appear in order: 
1. Further development of the systems mode1 in order to generate a more concise picture of the relationships that persist in education in the United States. This recommendation is general in nature but the significance placed on education in American soclety and the extensiveness of the Influence that it professes to command are justification In themselves for the full development of a political system of education.

2. A quantitative approach to analyzing the political world of the schools should be undertaken to further develop the concepts and themes considered in this thesis. A historical approach such as has been undertaken in this thesis provides valuable concepts without which quantitative analysis of the parameters of the political environment of the school would lose meaning. With such groundwork laid, the posstbilities are endless. Such studies could ut1lize the three themes developed in this thesis as the basis for in-depth analysis of controversy which confronts the schools. Attitude scales such as the Guttman Scale could be utillzed for any of the themes in order to analyze a variety of attitudes regarding the themes. On an overall basis, multiple regression could be employed to determine relationships between controversy and other demographic indicators. And controversy as such would be measured in any number of ways; content analysis of the media, successful bond issues passed, 
numbers of controversies apparent within the system and others. In such a manner, religion ethnic groups, political party, raclal balance, age distributions, sex ratios, welfare expenditures, degree of unionism and many other varlables could be used to attempt to develop significant relationships between the dependent and independent variables. However, one would also have to be prepared to work with data national in scope in some approaches. And in such cases, data such as defense expenditures, conscription data, religious affillations, national income versus corporate income, international turmoll and involvement, inflation indexes and many other facets of the soclety would have to be considered. Concurrent with the analysis of the variables, a prudent side approach would be that of attempting to determine causal relationships involved. To further analyze concepts involved, the three identified themes could be taken as dependent variables and explored with respect to the myriad variables previously mentioned. Such an approach would allow one to fully determine the causal and operative nature of the themes identified.

3. The use of the GINI Index would provide an additional means by which one could determine the distribution of educational benefits with respect to other factors. Such an approach could be incorporated with the multiple regression form of analysis or viewed in terms of causal 
relationships.

4. By the foregoing suggestions one should strive to determine the actual importance of each of the three themes in terms of educational controversy. This would allow further development of the concept of stress within the suggested mode1. 


\section{A SELECTED BIBLIOGRAPHY}

Adler, Norman and Harrington, Charles, eds. The Learning of Political Behavior. Glennview, Illinols: Scott Foresman and Company, 1970 .

Are American Teachers Free? Report of the Commission on Social Studies American Historical Association, Part XII. Howard K. Beale, chalrman. New York: Charles Scribner's Sons, 1936.

Balley, Stephen K.; Frost, Richard T.; Marsh, Paul E.; and Wood, Robert C. Schoolmen and Politics. Syracuse, New York: Syracuse University Press, 1962.

Balley, Stephen K. and Mosher, Edith K. ESEA: The Office of Education Administers A Law. Syracuse: Syracuse University Press, 1968.

Bauer, Wilhelm. "Public Opinion." Encyclopedia of the Social Sciences. New York: Macmillan, Inc., 1935.

Bendiner, Robert. The Politics of Schools. Benter Books. New York: The New American Library. Inc., 1970.

Bereiter, Car1. "Schools Without Education." Harvard Educational Review, XXXXII (Aug., 1972) pp 390-413.

Bestor, Arthur E. "The Retreat from Learning." National ParentTeacher, October, 1954, p. 28, 30, 32 .

Blanchard, Robert. "Boise School and Related Issues." Address to Portland Public School District Board, Portland, Oregon, Oct. 1, 1973.

Bond, Horace Mann. Negro Education in Alabama. Washington, D.C.: Associated Publishers, Inc., 1939.

"Boom in Protestant Schools," U.S. News and World Report, October 8, 1973, pp. 44-46.

Bowers, C. A. The Progressive Educator and the Depression. New York: Random House, 1969.

Brandt, Joseph. "This Too Happened in Pasadena." Public Education Under Critic1sm. Edited by C. Winfield Scott and Clyde M. Hill. New York: Prentice Hall, Inc., 1954. 
Brubacher, John S. Eclectic Philosophy of Education. Englewood Cliffs, New Jersey: Prentice-Ha11, Inc., 1962.

Bruner, Jerome S. The Process of Education. Vintage Books. New York: Alfred A. Knopf, Inc. and Random House, Inc., 1960.

Cahil1, Robert S. and Hencley, Stephen P., eds. The Politics of Education in the Local Community. Danville, Illinois:

Interstate Printers and Publishers, Inc., 1964.

The Committee of the Progressive Education Association on Social and Economic Problems. Report of the Committee. A Call to the Teachers of the Nation. New York: Progressive Education Association, 1933.

Conant, James B. "The Superintendent was the Target." Public Education Under Criticism. Ed. by C. Winfield Scott and clyde M. Hill. New York: Prentice-Ha11, Inc., 1954.

Corey, Arthur F., "Dr. Bestor's Wastelands." National Parent-Teacher, October, 1954, p. 29, 31, 32 .

Counts, George S. School and Society in Chicago. New York: Harcourt, Brace and Company, 1928 .

Counts, George S. Dare the School Build a New Social Order? New York: John Day Company, 1932.

Counts, George S. The Prospects of American Democracy. New York: John Day Company, 1938.

Counts, George S. Education and the Promise of America. New York: Macmillan Company, 1945.

Cremin, Lawrence A. The Transformation of the Schools. Vintage Books. New York: Alfred A. Knopf, Inc. and Random House, Inc., 1961.

Cremin, Lawrence A. The Genius of American Education. Vintage Books. New York: Alfred A. Knopf, Inc., and Random House, Inc., 1965.

Cubberly, Elwood P. Public Education in the United States. Rev. and en1. ed. New York: Houghton-Mifflin Company, 1934.

Davidson, W. Phillips. "The Public Opinion Process." Public Opinion Quarterly, XXII (Summer, 1958), 91-106.

Dawson, Richard E., and Prewitt, Kenneth. Political Soclalization. Boston: Little, Brown and Company, 1969. 
Dewey, John. The School and Soclety. Phoenix Books. 6th Impression. Chicago: University of Chicago Press, 1900.

Dewey, John. The Child and the Curriculum. Phoenix Books. 6th Impression. Chicago: University of Chicago Press, 1902.

Dobbins, Allen L. "Instruction at Adams." Phi Delta Kappan, LII (May, 1971), pp 516-519.

Dropkin, Stan; Full, Harold; and Schwarcz, Ernest, eds. Contemporary Amertcan Education. New York: The Macmillan Company, 1965.

Easton, David and Hess, Robert D. "The Child's Political World." Midwest Journal of Political Science, VI (Aug., 1962), pp. 229246.

Edwards, T. Bentley and Wirt, Frederick M. School Desegregation in the North. San Francisco: Chandler Publishing Company, 1967.

Enge1, Louis. "Port Washington, New York." The Saturday Review of Literature. September 8, 1951, pp. 6-7, 25-26.

"Financial Conditions in the Georgia School System," editorial. Schoo1 and Society, May, 1933, p. 577-78.

Fletcher, Jerry L. "Research and Evaluation at Adams." Ph1 Delta Kappan, LII (May, 1971), pp. 523-526.

Grannis, Joseph C. "The School As a Model of Society." Harvard Graduate Schoo1 of Education Bulletin, XII (Fa11, 1967), pp. 1517.

Graubard, Allen. "The Free School Movement." Harvard Educational Review, XXXXII (August, 1972), pp 351-374.

Gutek, Gerald Lee. An Historical Introduction to American Education. New York: Thomas Y. Crowe11 Company, 1970.

Hart, Harold, ed. Sumerhill: For and Against. New York: Hart Publishing Company, Inc., 1970.

Havighurst, Robert J., ed. Metropolitanism; Its Challenge to Education, The Sixty-seventh Yearbook of the National Soclety for the Study of Education, Part 1. Chicago: University of Chicago Press, 1968.

Hays, Samuel P. The Response to Industrialism. Chicago: University of Chicago Press, 1957. 
Henry, Nelson B., ed. Social Forces Influencing American Education. The Sixtieth Yearbook of the National Soclety for the Study of Education, Part 2. Chicago: University of Chicago Press, 1961.

H1gham, John. "The Mind of a Nativist: Henry F. Bowers and the A. P. A." American Quarterly, IV (Spring, 1952), 16-24.

Higham, John. Strangers in the Land. Atheneum. New York: by arrangement with Rutgers University Press, 1963.

A History of Freedom of Teaching in American Schools, Report of the Commission on the Soctal Studies American Historical Association, Part XVI. Howard K. Beale, Chalrman. New York: Charles Scribner's Sons, 1941.

Hofstadter, Richard. The Age of Reform. Vintage Books. New York: Alfred A. Knopf, Inc. and Random House, Inc., 1955.

Hulburd, David. This Happened in Pasadena. New York: Macmillan Company, 1951.

Hurwitz, Emanuel and Tescon1, Charles A., eds. Challenges to Education. New York: Dodd, Mead and Company, 1972.

Iannacone, George. "If I Had My Way." Councll for Basic Education BuIlet1n, XVIII (October, 1973), 11-18.

Itzkoff, Semour W. Cultural Pluralism and American Education. Scranton, Pennsylvania: International Textbook Company, 1969.

"The John Adams Team." Phi Delta Kappan, LII (May, 1971), 514.

Johnson, Marletta. Thirty Years With an Idea. Teachers College, Columbia University, 1939.

Katz, Michael B. Class, Bureaucracy and Schools. New York: Praeger Publishers, Inc., 1969.

Keller, Bill. "Report card: Busing alleviates crowding, Bolse school tension." Oregonian. September 24, 1973.

Ke1ler, Bill. "Removal of Boise principal urged over 'ractst' remarks." Oregonian. September 25, 1973.

Keller, Bill. "Beleaguered princlpal finds supporters among parents who see deeper problems." Oregontan. September 30, 1973. 
Key, V. O. Jr. Southern Politics. Vintage Books. New York: Alfred A. Knopf, Inc. and Random House, Inc., 1949.

Key, V. 0. Jr. Public Opinion and American Democracy. New York: Alfred A. Knopf, Inc., 1961.

Kilpatrick, James T. "Arizona bids to bring back education even if it sets liberal factions twitching," The Sunday Oregonian, January 20,1974 .

Kirst, Michael w. ed. The Politics of Education at the Local, State and Federal Levels. Berkley, California: McCutchan Publishing Company, 1970.

Kirst, Michael W. and Wirt, Frederick. The Political Web of American Schools. Boston: Little, Brown and Company, 1972.

Koerner, James D. Who Controls American Education? Boston: Beacon Press, 1968.

Kozo1, Jonathan. Death at an Early Age. Bantam Books. New York: by arrangement with Houghton-Mifflin Company, Boston, 1970.

Kozo1, Jonathan. Free Schools. Bantam Books. 1st rev. ed. New York: by arrangement with Houghton-Mifflin Company, Boston, 1972 .

Langton, Kenneth P. "Peer Group and School and the Political Social1zation Process." American Political Science Review, LXI (Summer, 1967), 751-58.

Langton, Kenneth P. and Jennings, Kent M. "Political Soclalization and the High School Civics Curriculum in the United States." American Political Sclence Review, LXII (Sept., 1968), 852-867.

Lleberman, Myron. The Future of Public Education. Chicago: University of Chicago Press, 1960.

Litt, Edgar. "Civic Education, Community Norms, and Political Indoctrination." American Sociological Review, XXVIII (Feb, 1963), 69-75.

Mackinnon, Frank. The Politics of Education. Toronto: University of Toronto Press, 1960.

Male, George A. The Struggle for Power. Beverly Hills, California: Sage Publications, 1974.

Manning, Walton. "Academic Freedom and Politics." Phi Delta Kappan, XXIV (June, 1953), 398-9. 
Manning, Dr. Walton. "Education and the Negro"-- "The Low Record on Achievement." Miam1 News. Sept. 22, 1961.

Manning, Dr. Walton. "Education and the Negro"-- "The Gained in the North." Miami News. Sept. 23, 1961.

Manning, Dr. Walton. "Education and the Negro"-- "Emotions Apt To Taint Fact." Miami News. Sept. 24, 1961.

Manning, Dr. Walton. "Education and the Negro"-- "Opportunity Opens Doors to 'Spirit'." Miami News, Sept. 25, 1961.

Martin, Lawrence. "Denver, Coloardo." The Saturday Review of Literature. September 8, 1951, pp. 9-10, 31 .

Massailas, Byron G. Education and the Political System. Reading, Massachusetts: AddIson-Wesley Publishing Company, 1969.

Mayer, Martin. The Schools. Anchor Books. New York: by arrangement with Harper and Brothers, 1961.

MeIvin, A. Gordon. Education: A History. New York: John Day Company, 1946.

Morrison A. and McIntyre, D. Schools and Socialization. Baltimore: Penguin Books Inc., 1971.

Muller, Herbert J. "Education for the Future." The American Scholar. XXXXI (Summer, 1972), 377-388.

Munger, Frank J., and Fenno, Richard F. Jr. National Politics and Federal Ald to Education. New York: Syracuse University Press, 1962.

National Education Association. Addresses and Proceedings. Washington, D.C., 1880.

National Soclety for the Promotion of Industrial Education. Proceedings of the Organizational Meetings. Bulletin No. 1. New York, 1907.

Ne11, A. S. Summerhill. with a Foreward by Erich Fromm. New York: Hart Publishing Company, 1960.

"Once-heralded method of teaching figures doesn't seem to add up," The Sunday Oregonian, Oct. 21, 1973.

Packard, Vance. "Are We Becoming a Nation of Illiterates," Readers Digest, CIV (Apri1, 1974) pp. 81-85.

Parker, John L. "Teacher Trainin at Adams." Phi Delta Kappan, (May, 1971), 520-522. 
The Pasadena Story. National Commission for the Defense of Democracy Through Education, John W. Davies, chairman. Washington, D.C.: National Education Association, 1951.

"The P1ight of the Chicago Schools," editorial. School and Society, XXXVII, (May, 1933), 578.

Robinson, Donald W. "Are They Quietly Killing John Adams." editorial, Phi Delta Kappan, LIII (October, 1971), 81.

Rogers, Dav1d. 110 Livingston Street. Vintage Books. New York: Random House, Inc., 1968.

Root, E. Merri11. Brainwashing in the High Schools. New York: DevinAda1r Company, 1959.

"Schools To Stress '3Rs'", The Oregon Journal, September 7, 1973.

Schwartz, Robert B. "Profile of a High School: An Introduction." Phi Delta Kappan, LII (May, 1971), 515.

Scott, Winfleld C., and H111, Clyde M., eds. Public Education Under Crit1c1sm. New York: Prent1ce-Ha11, Inc., 1954.

Silberman, Charles E. Crisis in the Classroom. Vintage Books. New York: Random House, Inc., 1970.

Smith, Mortimer, ed. "The Politicalization of Education." Counc11 for Basic Education, Bulletin, XVII (May, 1973), 1-3.

Stoddard, George D. The Meaning of Intelligence. New York: Macmillan Company, 1943.

Stormer, John A. None Dare Call It Treason. Florissant, Missour1: Liberty BelI Press, 1964.

"Strengthening Alternative HIgh Schools." Center for New Schools. Harvard Educat1onal Review, XXXXII (August, 1972), 313-350.

Terman, L. M. The Measurement of Intelligence. Boston: Houghton Miffin Company, 1910.

Thomas, Lawrence G. "The Meaning of 'Progress" In Progressive Education." Educational Administration and Supervision, XXXII (Oct., 1946), 392-399.

Toffler, Alvin. Future Shock. Bantam Books. New York: by arrangement with Random House, Inc., 1970.

Togman, W. M. "Eugene, Oregon." The Saturday Review of Literature. September 8, 1951, pp. 10-12. 
Veritas Foundation. The Great Deceit, research director, Zygmund Dobbs. West Sayville, New York: Veritas Foundation, 1964.

Weeks, Stephen B. The History of Public School Education in Alabama. Report of U. S. Bureau of Education, Bulletin No. 12, Washington, D. C.: U. S. Government Printing office, 1951.

Wertheimer, Patricia A. "School Climate and Student Learning." Phi Delta Kappan, LII (May, 1971), 527-530.

"Why Can't Johnny Calculate?", The Oregon Journal, Oct. 20, 1973.

Whyte, William H. Jr. The Organization Man. Anchor Books. Garden City, New York: Doubleday and Company, Inc., 1956.

Wiebe, Robert $H$. The Search for Order The Making of America. New York: H111 and Wang., 1967.

Zeigler, Harmon. The Political Life of American Teachers. Englewood Cliffs, New Jersey: Prent1ce-Ha11, Inc., 1967.

Zeigler, Harmon, and Johnson, Kar1 F. The Politles of Education in the States. New York: Bobbs-Merrill Company, Inc., 1972. 